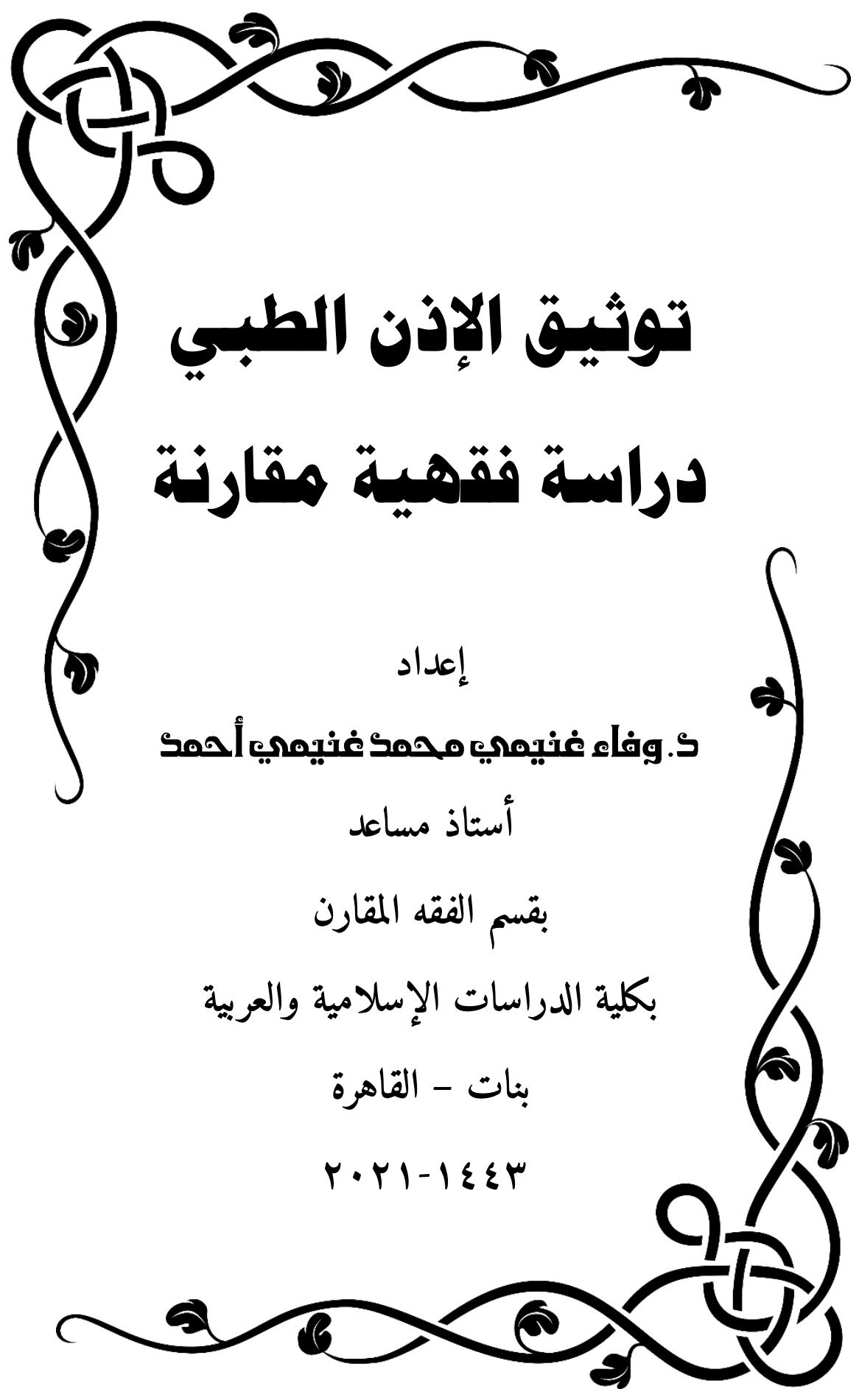




\section{توثيق الإذن الطبي دراسة فقهية مقارنة}

\section{وفاء غنيمي محمد غنيمي أحمد}

قسم الفقه المقارن، كلية الدراسات الإسلامية والعربية جامعة الأزهر ، القاهرة، مصر - (2) - مص البريد الإكتروني: wafaa.ghonemy@azhar.edu.eg الملخص:

يهدف البحث إلى بيان معنى توثيق الإذن الطبي، وأنواعه وطرقه، مع تقدم الوسائل، وخراب الذمم، وبيان حكم كتابة الوثائق، وأهميتها، وطرق التوثيق لونيق والفرق بين الإثبات والتوثيق، وأن الكتابة والثهادة الخطية أو الإكترونية من ون وسائل التوثيق، وبيان حوكمة توثيق الإذن الطبي والإذن الطبي هو ذلك الحماية لذلك الطبيب من خطأ غير مقصود وتشخيص مرود.

وقد اتبعت في هذه الدراسة المنهج الاستقرائي التحليلي المقارن في الفقه الإسلامي والقانون الوضعي مع ذكر آراء الفقهاء والرأي الراجح، وسبب الترجيح، ولأن هذه الثريعة الإسلامية الصالحة لكل زمان ومكان فقد وضعت النصوص التي تعمل على المحافظة على النفس والمال وتحفظ الحقوق وتمنع التنازع وتحرم الإضرار بالأموال والأنغس.

ومـن أهـــ النتـائج التـي توصـلت إليهــا: الإذن الطبـي عقــــــين الطبيـب والمريض، يتعهد الطبيب بموجبه أن يعالج المريض وفق الأصول المتعارف عليها عند أهل الطب. يلزم الطبيب فتح ملف طبي للمريض يرجع إليه وهو وثيقـة رسـية سـرية. الإذن الطبـي يأخذ حكم التـداوي. يجب توثيق الإذن الطبي من باب حفظ الحقوق. ينتهي توثيق الإذن الطبي يما ينتهي به الإذن 


\section{توثيق الإذن الطبي دراسة فقهية مقارنة}

الطبـي. حوكمـة توثيق الإذن الطبـي: هـي مجموعـة مـن القوانين والـنظم والقرارات التي تهف إلى تحقيق الجودة والتميز في أداء توثيق الإذن الطبي

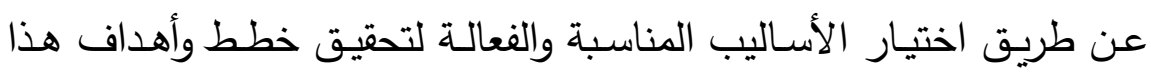

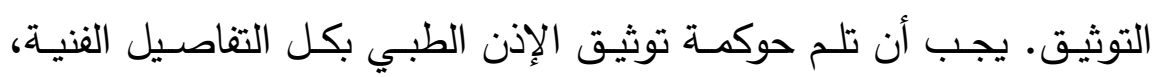
والقانونية لتوثيقه. الكلمات المفتاحية: توثيق، إذن، طبي، تداوي ، حوكمة. * * $*$ * $*$ * 
Documentation of Medical Consent ${ }^{1}$ : A Comparative Juristic Study

\section{Wafaa Ghoneimi Muhammad Ghoneimi Ahmed}

Department of Comparative Jurisprudence, Faculty of Islamic and Arabic Studies, Al-Azhar University, Cairo, Egypt.

\section{Email: wafaa.ghonemy@azhar.edu.eg}

\section{Abstract:}

The present study aims at defining what is meant by documenting medical consent, its types, and its methods during a time where means are advanced, and conscience is ruined. It shows the judgment of writing documents, their importance, methods of documentation and the difference between evidence and documentation. It argues that writing and written or electronic documents are among the means of documentation. It explores the governance of medical consent documentation. It indicates that medical consent protects doctors from unintended errors and wrong diagnosis. The study adopts an inductive, analytical, comparative approach in Islamic Jurispredence, and the positive law. It mentions the opinions of jurists, the most preponderant opinion, and the reason for giving preference of an opinion over another. Since Islamic Sharia is valid for every time and place, it provides texts that preserve souls, money, rights, prevent conflicts, and forbids causing harm to money and souls. Some of the most important conclusions of the study include the following:

1 A consent by a patient or his guardian given to a medical doctor to perform whatever he deems suitable to the patient. 
- Medical consent is a contract between a doctor and a patient, according to which the doctor undertakes to treat the patient in accordance with the principles recognized by medical scholars.

- Doctors have to open a medical file for patients as a reference and it is considered a confidential official document.

- The ruling of medical consent is similar to that of medical treatment.

- Medical consent must be documented to preserve rights.

- Documentation of medical consent ends in line with the end of the medical consent.

The governance of documenting medical consent: it is a set of laws, regulations and decisions aiming at achieving quality and excellence in the process of documenting medical consent. This is done through choosing the suitable and effective methods to achieve the plans and goals of this documentation.

The governance of documenting medical consent should include all the technical and legal details for documentation.

Keywords: Documentation, Consent, Medical, Treatment, Governance. 


\section{بسم الله الرحمن الرحيم}

\section{المقدمة}

الحمد الله حمد الثاكرين الحمد لله سرمدا إلى يوم الدين الحمد لله حمدا كثيرا طيبا مباركا فيه، الحمد لله رب العالمين أولا، والحمد الله رب ئوم الثبن العالمين أخرا، والحمد الله كما ينبغي لجلال وجهه وعظيم سلطانه، وأصلي وأسلم على المبعوث رحمة للعالمين نبينا محمد وعلى آله وصحبه ومن وهن

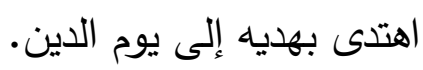

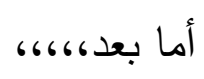

فإن العافية نعمة لا يعلم مقدارها إلا من فقدها أو فقد بعضها، فما بالك بمن أصابته الأمراض والأسقام والعلل وصار بين المستشفيات يبحث عن أمل في العلاج والثفاء والنجاة -وما ذلك على الله بعزيز - أن تعود إليه الصحة ويلبس رداء العافية، وفي سيدنا أيوب عليه السلام المثل الكبير في العطاء ثم المنع ثم العطاء بغير حساب بعد الصبر على المحن جميعها؛ مرض وابتلاء وفقر وحاجة، ولكن يأتي الصبر على البلاء والتزام الرجاء والقلب الموصول برب العالمين؛ ليطلب النجاة فتأتي الاستغاثة فتتزل في عين الإجابة، فيرتفع البلاء، وتعود العافية، وتتزل العطايا، وتغمر الجميع فيأتي ما لم تتوقعه بصبرك يا نبي الله، فكنت مثلا في البلاء، وقدوة في

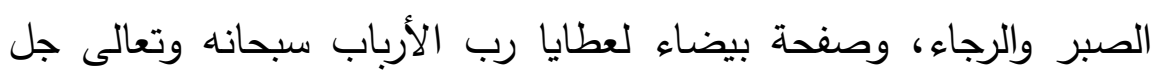
شأنه.

ولقد أثار فكري مسألة الإذن الطبي وكيف أن الطبيب الذي عمله الكثف والدواء والتشخيص والعلاج قابل أن يكون مخطئا حينا ومصيبا 


\section{توثيق الإذن الطبي دراسة فقهية مقارنة}

أحيانا، وبعض نتائجه موت وفقدان، وكثير منها شفاء بإذن الله، لذا فقد كان الإذن الطبي حماية لذلك الطبيب من خطأ غير مقصود وتشخيص مردود، ولكن كيف يكون هذا الإذن ساريا؟ والمريض إما أن يكون قادراً على العطاء مفكراً في المآل أو يكون غير قادر على الحديث ولا إعطاء الاليل، وهذا الإذن الذي نحن بصدده هل يحتاج إلى توثيق ونوع من التثبت والحماية؛ حتى لا يدع مريض بعدم الإعطاء أو طبيب عند مجاوزة الحد بأخذه ذلك الإذن ووضعه في الملف الطبي للمريض...لذا فقد استخرت الله واستشترت قبل الكتابة في موضوع توثيق الإذن الطبي لما رأيته من الأهمية بمكان، وبخاصة أني لم أعثر على كتب في التوثيق، وإنما وجدت بعض المعاصرين قد كتب في الإذن الطبي للقيام بالعمليات الجراحية، أو الإذن في الأمور المستعجلة وقد آثرت الاقتصار في هذا الموضوع على توثيق الإذن الطبي لما يحدث من إفراط وتقريط من كلا الجانبين. 
تكمن مشكلة البحث في الأمور الآتية:

- ضياع الحقوق لعدم الحرص على أخذ الإذن في المعالجات الطبية المختلفة، أو إساءة استخدامه.

- النزاع بين المريض والطبيب وتحمل المسؤولية عند وجود خطأ في

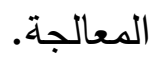
- التعدي على الأطباء والهيئة الصحية عند عدم إمكانية المعالجة أو التقصير فيها.

- إنكار الحقوق المترتبة على العمل الطبي؛ كجدد الأجر أو المماطلة فيه أو تقسيم العمل الطبي على مراحل لم يبينها الطبيب للمريض كي يحصل على أجور متعددة لعمل طبي واحد.

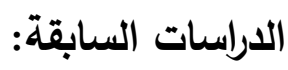

من خلال بحثي وجدت مشايخ وعلماء أجلاء كان لهم السبق في تناول ودراسة الإذن الطبي ومن ذلك:

| - الإذن الطبي في إجراء العمليات الطبية أحكامه وأثره. الثيخ / الثمات هاني بن عبد الله محمد الجبير الطبي منشور على موقع صيد الفوائد. ץ- الإذن الطبي في الحالات الطارئة دراسة فقهية مقارنة د. محمد بن مطر السهلي، أستاذ الفقه المشارك بجامعة أم القرى منشور بالعدد الحادي والثلاثين، الجزء الرابع بمجلة كلية الثريعة والقانون بطنطا جامعة الأزهر 17 . r م. 


\section{توثيق الإذن الطبي دراسة فقهية مقارنة}

r- الإذن الطبي في الحالات الجراحية المستعجلة د. عصام محمد

سليمان موسى بحث منشور بالدورة التاسعة عشرة بإمارة الثارقة دولة الإمارات العربية المتحدة - منظمة المؤتمر الإسلامي مجمع الفقه الإسلامي

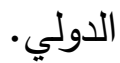

أما عن توثيق الإذن الطبي فبعد البحث على الثبكة العنكبوتية والاستشارة والسؤال لم أعثر على دراسة تناولته إلى الآن، وأسأل الله أن يكون

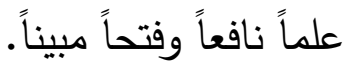

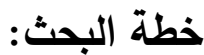

وقد قسمت البحث إلى: مقدمة، وسبعة مباحث، وخاتمة:

المبحث الأول: ماهية توثيق الإذن الطبي، ويشتمل على أربعة

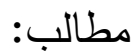

المطلب الأول: ماهية التوثيق.

المطلب الثاني: ماهية الإذن الطبي.

المطلب الثالث: العلاقة بين الإذن الطبي والإقرار الطبي والملف

المطلب الرابع: تعريف توثيق الإذن الطبي.

المبحث الثاني: أنواع ووسائل توثيق الإذن الطبي.

ويشتمل على ثلاثة مطالب:

المطلب الأول: أنواع الإذن الطبي.

المطلب الثاني: أنواع توثيق الإذن الطبي. 
المطلب الثالث: وسائل توثيق الإذن الطبي.

المبحث الثالث: حكم كتابة الوثائق وأهميتها. ويشتمل على مطلبين:

المطلب الأول: حكم كتابة الوثائق.

المطلب الثاني: أهمية توثيق الإذن الطبي.

المبحث الرابع: شروط الموثق والإذن الطبي، ويشتمل على خمسة

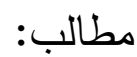

المطلب الأول: إسلام الموثق.

المطلب الثاني: البلوغ والعقل.

المطلب الثالث:عدالة الموثق.

المطلب الرابع: العلم بفقه الوثيقة.

المطلب الخامس: شروط الإذن الطبي.

المبحث الخامس: حكم توثيق الإذن الطبي.

ويشتمل على مطلبين:

المطلب الأول: حكم الإذن الطبي.

المطلب الثاني: حكم توثيق الإذن الطبي.

المبحث السادس: انتهاء الإذن الطبي.

المبحث السابع: حوكمة توثيق الإذن الطبي.

المطلب الأول: المقصود بالحوكمة. 


\section{توثيق الإذن الطبي دراسة فقهية مقارنة}

المطلب الثاني: حوكمة توثيق الإذن الطبي.

$$
\text { ملاحق: نموذج للإقرار الطبي. }
$$

الخاتمة: اشتملت الخاتمة على أهم النتائج والتوصيات التي توصلت إليها

$$
\text { من خلال البحث. }
$$

واللة أسأنُ أن يجعله خالصا لوجهه الكريم، وأن يتقبله بقبول حسن

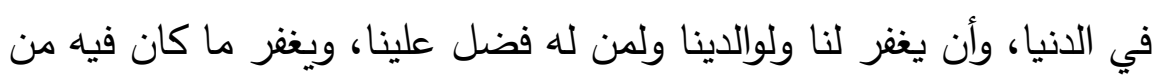
خطأ وأن ينفع به، ويجعلني وإياكم من أهل القرآن الذين هم أهل الله وخاصته، ويكرمنا في الدنيا بالستر والمعافاة والنجاة من الفتن، ويرزقنا في

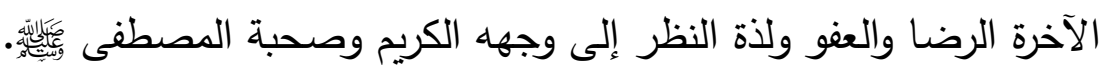

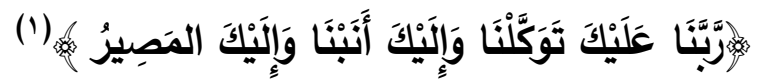

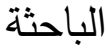

* * $\quad * \quad * \quad * \quad *$

(1) سورة الممتحنة جزء من آية (؟). 


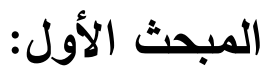

\section{ماهية توثيق الإذن الطبي}

المطلب الأول: - - (الم

ماهية التوثيق

التوثيق لغة: يأتي بمعاني متعددة منها:

- الثد، والإحكام والعهد والأمر والائتمان.

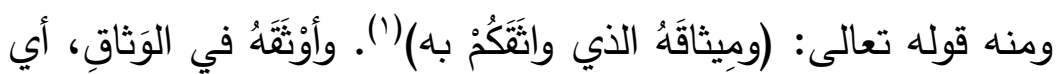

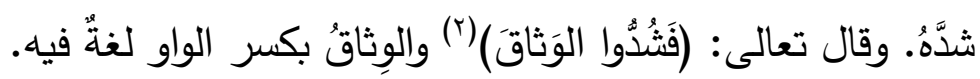

وهو مصدر وثق الثيء إذا أحكمه وثبته، وثلاثيه: وثق. يقال: وثق

الثيء وثاقة: قوي وثبت وصار محكما، والوثيقة: ما يحكم به الأمر، والوثيقة: الصك بالدين أو البراءة منه، والمستند، وما جرى هذا المجرى وله والجمع وثائق. والموثق من يوثق العقود، ويقال: أخذ بالوثيقة في أمره أي بالثنقة(ץ).

والوثيقة هي: "الورقة التي يكتب فيها الموثق، وسميت هذه الورقة وثيقة؛ لأن مادة "وثق" تتبئ عن الربط، فهي شريط كل من المتعاقدين بما

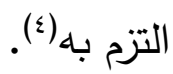

$$
\begin{aligned}
& \text { (Y) (Yورة المائدة جزء من آية (V) (Y). }
\end{aligned}
$$

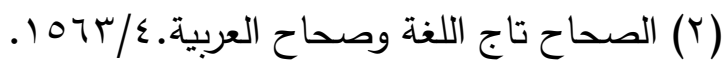

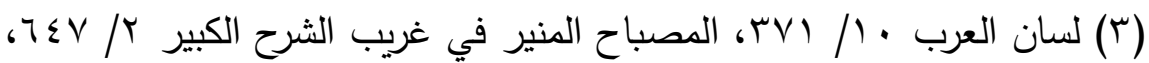

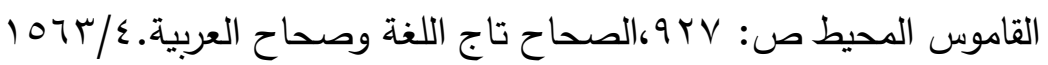

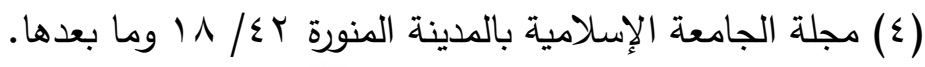


والوثيقة الثرعية هي: "الورقة التي يدون فيها ما يصدر من شخص أو أكثر من التصرفات أو الالتزامات أو الإسقاطات أو نحو ذلك، على وجه التهات يجعله منطبقًا على القواعد الثرعية، ومستوفيًا لجميع الثروط التي اشترطها

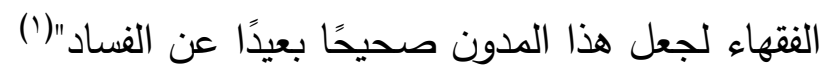
ويسمى الفقهاء علم التوثيق بعلم الشروط والمحاضر والسجلات، وفيه كتب كثيرة مؤلفة عند كل المذاهب الإسلامية قديمًا وحديثًا(؟). التوثيق اصطلاحًا: لقد عرف العلماء علم التوثيق بتعريفات متعددة أهمها ما يلي:

( ) عرفه صاحب الفتوحات الإلهية بقوله: الأمر الذي يحصل به التقوي على الوصول للحق(r).

وهذا التعريف غير جامع ولا مانع؛ حيث دخل فيه ما لا يعد توثيقا كالدعوى، فإنها من الأشياء التي يتقوى بها للوصول إلى الحق ومع ذلك لا تعتبر من التوثيق في شيء(๕)، ولأنه عرف التوثيق بالوسائل التي يقصد بهاء حفظ الحقوق واستيفائها، والفرق شاسع بين حفظ الحقوق واستيفاء الحقوق، فقد ثبتت الحقوق بما لا يمكن أن تحفظ به، وما تحفظ به، تثبت به،

ويستغنى به عند الطلب(0).

$$
\text { (Y) (Y) المرجع السابق نفسه. }
$$

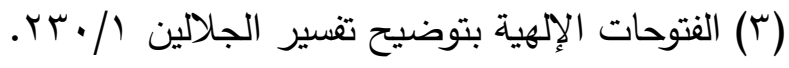

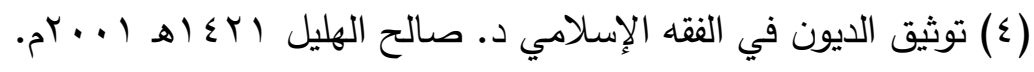

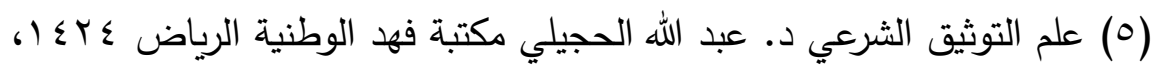

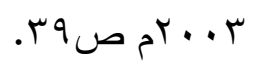


r) عرفه الأستاذ الفاضلي بقوله: "التوثيق في الاصطلاح هو: علم يبحث فيه عن كيفية إثبات العقود والالتزامات والتصرفات وغيرها، على وجه يصح الاحتجاج والتمسك به"(')، وهذا تعريف للتوثيق كعلم وليس تعريفا للوثيقة الشرعية والفرق بينهما واضح وجلي (؟). r) وعرفه الدكتور نزيه كامل حماد بأنه: عبارة عن مجموعة من الوسائل التي تؤدي إلى استيفاء الحق عند تعذره من المدين، أو إثباته في زمنه عند الإنكار (r) (بل)

وهذا التعريف أفضل من سابقه إلا أنه يؤخذ عليه حصر وسائل التوثيق، في نوع من أنواع وسائل التوثيق الثرعي، وهي الكتابة لحفظ الدين

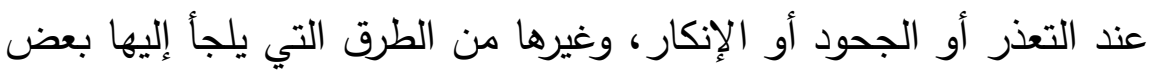
الناس لأكل أموال الناس بالباطل...أما التوثيق فشرعه الثارع الحكيم لحفظ الحقوق الشرعية كلها، من ديون وعقارات، وغيرها، ومما هو قديم أو حادث، وليس محصورا في نوع واحد فقط من أنواع الحقوق الشرعية كالديون مثلان(๕)...

0) جعل المعاملات محكمة، بأن تكون صحيحة، مشتملة على الوثيقة

(1) مذكرات في علم التوثيق صعء، علم التوثيق الثرعي د. عبد الله الحجيلي

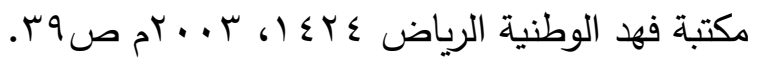

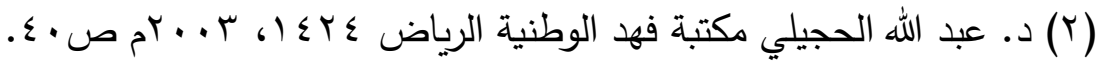
(r) مجلة البحث العلمي والتراث الإسلامي - الصادرة عن كلية الثريعة

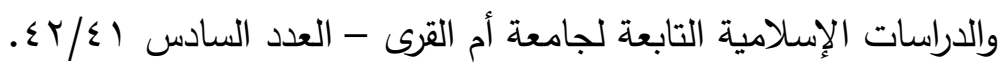

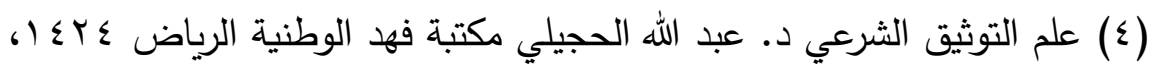

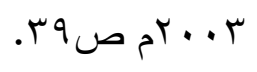




\section{توثيق الإذن الطبي دراسة فقهية مقارنة}

التي تصونها من التلاعب، وتكفل إنجازها على الوجه المشروع المتقق

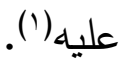

واستدل المعرف بقوله: والفقهاء إن لم يلتزموا ضابطا معينا فالمستوعب لكلامهم يجد اصطلاحهم على هذا الضابط شاخصا أمام العين عند تعريفهم للرهن، أو الضمان، والوقف والوصية، ففي سياق الحديث عن كل أمر من هذه الأمور يقولون إنه للتوثيق، أو لضمان الحقوق، أو لمنع

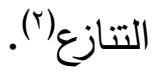

ع) عرفه رئيس اتحاد موثقي مصر: بكونه علما يبحث في كيفية إثبات العقود والتصرفات والالتزامات على وجه يحتج بهاه(؟). وعرفه عبد الله المشعل بقوله: مجموعة من الوسائل التي تؤدي إلى

استيفاء الحق عند تعذره من المدين أو إثباته في ذمته عند الإنكار (๕). وقيل التوثيق بمعناه العام الثامل لكل طرقه هو: الوسيلة التي تضمن تحصيل الحق وصيانته عن الجحد والضياع(ه).

(1) بين الشريعة والقانون نظرات في توثيق المعاملات المالية، عبد اللطيف

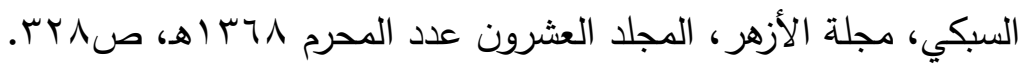

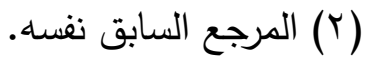
(r) ماهية علم التوثيق بقلم أ. وليد فهمي على موقع اتحاد موثقي مصر بتاريخ

$$
\cdot r \cdot r \cdot r / r
$$

(ع) التوثيق بالكتابة في الفقه الإسلامي عبد الله حمد إبراهيم المشعل، المجلد

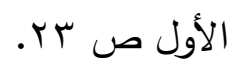

(0) المرشد إلى الصكوك الحقوقية، د.محمد أحمد العمر، مطبعة بغداد، ط:Y، 
والراجح هو ما عرفه الدكتور الحجيلي: هو مجموعة من العقود الشرعية المحكمة، لتأكيد الحق واستقراره في يد صاحبه، أو في ذمة غيره، أو إثباته عند التنازع أمام القضاء (').

وهذا التعريف جامع لجميع الوسائل وما يستجد من كل شيء تحفظ به الحقوق ويؤدي الغرض الثرعي المقصود من الوسيلة، وما يصلح أن يكون وسيلة شرعية في عصرنا لحفظ الحقوق بالكتابة، أو بالكمبيوتر أو بالبطاقة أو بأجهزة الجوال أو الصورة أو الفيديو وغير ذلك مما يستجد مع الأيام

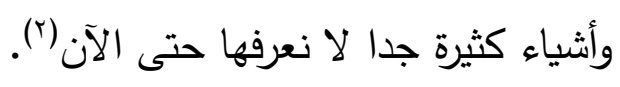
* $* \quad * \quad * \quad * \quad *$

(1) مذكرات في علم التوثيق صع، علم التوثيق الشرعي د. عبد الله الحجيلي

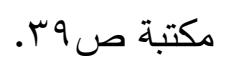

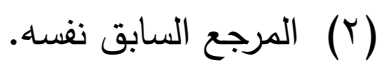




\section{توثيق الإذن الطبي دراسة فقهية مقارنة}

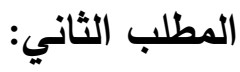

ماهية الإذن الطبي

\section{تعريف الإذن الطبي:}

مركب إضافي يتكون من لفظين الإذن والطبي.

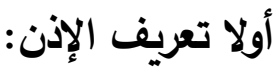

الإذن في اللغة: يأتي بمعان متعددة؛ منها: الإباحة والرخصة والإعلام

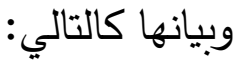

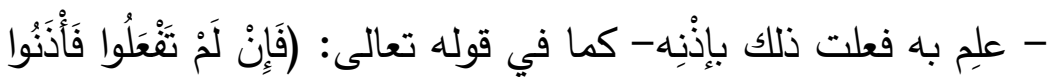

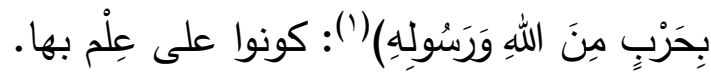

- أمر وقضى به ؛ منه قوله تعالى: (فِي بُيُوتٍ أَذِنَ اللهُ أَنْ تُرْفَحَ)(؟).

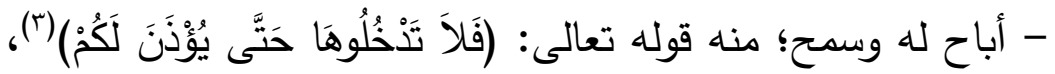

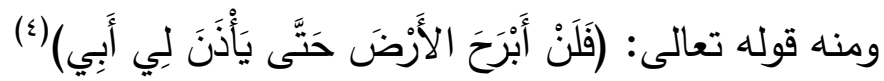

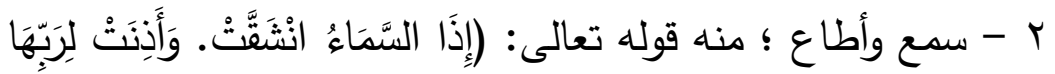
وَحُقََّتْْ)(م)

وفي الشرع: فلك الحَجْر وإطلاق التصرف لمن كان ممنوعًا شرعًا

(1) سورة البقرة جزء من آية رقم (YVq).

(Y) سورة النور جزء من الآية رقم (דr).

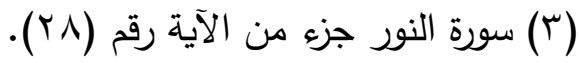

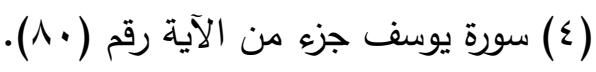

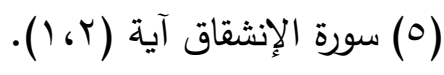




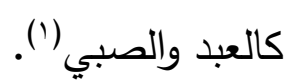

وقال ابن الكمال: فك الحجر وإطلاق التصرف لمن كان ممنوعا شرعا وقال الراغب: الإذن في الثيء الإعلام بإجازته والرخصة فيه(؟). وقد جمع السهلي بين التعريفين بقوله: الإذن هو إباحة التصرف

$$
\begin{aligned}
& \text { والرخصة في أمر كان ممنوعا(). } \\
& \text { ثانيًا تعربف الطبي: }
\end{aligned}
$$

لغة: من (طَبَّ) الطاء والباء، أصلان صحيحان، أحدهما يدل على علم بالثيء ومهارة فيه. والآخر على امتداد في الشيء واستطالة فالأول: الطب، وهو العلم بالثيء. يقال: رجل طب وطبيب، أي عالم حاذق(ء). والطِّبّ اصطلاحًا: علم يتعرف مِنْهُ أَحْوَال بدن الْإِنْسَان من جِهَة مَا يَصح وَيَزُول عَن الصِحَّة ليحفظ الصِحَّة حَاصِلَة ويستردها زائلة (ه) ، وقيل هو: علم بقوانين تعرف منها أحوال البدن من جهة الصحة وعدمها، وصاحبُ هذا العلم طبيب(ا)وقوقيل هو : رضى الثخص وقبوله بأن يجرى له له -أو لمن هو ولي عليه- جملة الأعمال التي يراد منها حفظ الصحّة أو هولئ

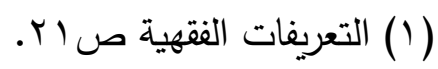

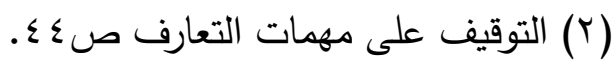

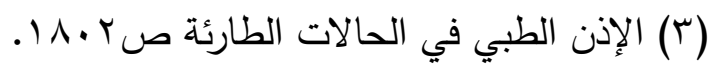

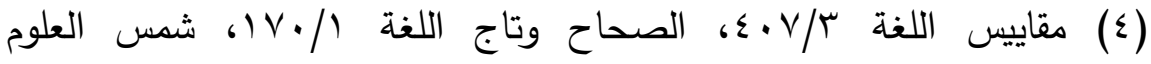

$$
\text { . } \varepsilon \cdot \varepsilon) / V
$$

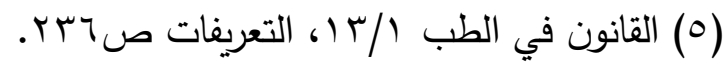

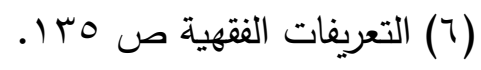




\section{توثيق الإذن الطبي دراسة فقهية مقارنة}

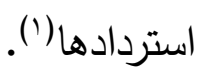

والذي أرجحه: هو علم بأحوال بدن الإنسان ونفسيته من جهة الصحة وعدمها وكيفية علاجه ليحافظ على صحته ويسترد زائلها (r).. لأنه جمع بين الإنه الصحة النفسية والبدنية.

ويمكن أن يعرف الإذن الطبي بأنه: موافقة المريض ذي الأهلية الكاملة أو وليه على جميع الإجراءات والفحوصات اللازمة لتشخيص الداء واتخاذ ما يلزم للوصول للشفاء بالأدوية أو بالتخخل الجراحي أو الأ

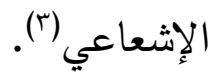

وكما يقول صاحب الموسوعة الطبية الفقهية إن الإذن الطبي: هو إقرار المريض بالموافقة على إجراء ما يراه الطبيب مناسبا لله من كثف سريري وتحاليل مخبرية ووصف دواء وغيره من الإجراءات الطبية التي تلزم لتشخيص المرض وعلاجه (؛). $* * \quad * * \quad * *$

(1) الإذن في إجراء العمليات الطبية أحكامه وأثره د هاني الجبير ص عـ. منشور

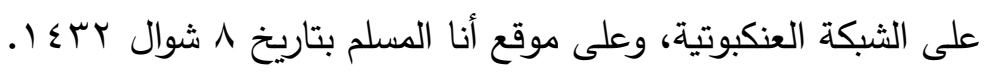

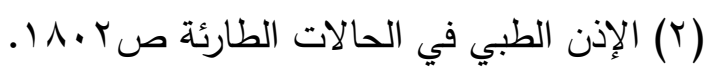

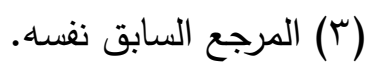

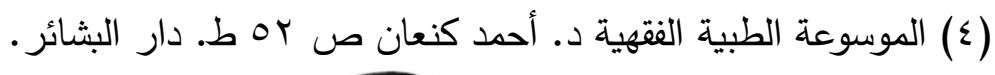




\section{المطلب الثالث:}

العلاقة بين الإنن الطبي والإقرار الطبي والملف الطبي

وإذا كـان الإذن الطبي عقد بين الطبيب والمـريض، يتعهد الطبيـب

بموجبه أن يعالج المريض وفق الأصسول المتعارف عليها عند أهل الطب، لإنبي، وبعض القوانين الطبية في العالم تعتبر مجيء المريض إلى العيادة بإرادته، أو موافقته على دخول المستشفى، إذنا منـه يحق للطبيب بموجبه أن يجري أنياء عليه مـا يـراه مناسبا مـن أنـواع التشـخيص والعـلاج حسب الأعراف الطبيـة المتفق عليها(')، وهو ما يعرف بالقرار الطبي.

وأما الملف الطبي: هو سجل طبي للمريض، يشتمل على المعلومات الأساسية للتعريف بالمريض، كالاسم والعمر والجنس (ذكر أم أنثى) والعنوان

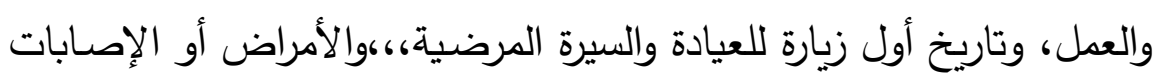

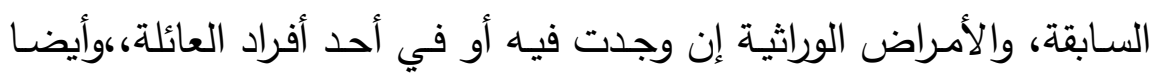
تدون نتائج الفحوصات المخبرية أو الإشعاعية والمعالجات الدوائية والجراحية

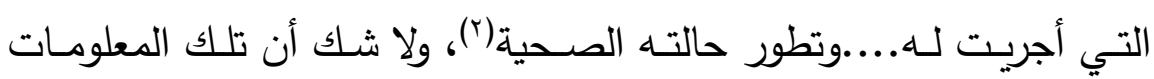
تكـون مهمـة على المستوى الثخصـي ومستوى الـدول في الإحصـاءات المختلفة مع التطور في طرق استخدام التكنولوجيا، وظهور أمراض جديدة. أحكام الملف الطبي:

- يلزم الطبيب فتح ملف طبـي للمريض للرجوع إليـه عند الحاجـة؛ لأسـباب مهنيـة أو قانونيـة أو علميـة، وهذا عـام في كل طبيـب سـواء كان

(1) الموسوعة الطبية الفقهية د. أحمد كنعان ص ro ط. دار البشائر.

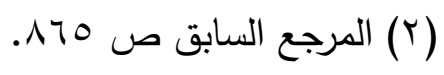




\section{توثيق الإذن الطبي دراسة فقهية مقارنة}

حكوميا أو خاصا.

- الملف الطبـي وثثيقة رسمية يرجـع إليهـا في كثيـر مـن القضـايا،

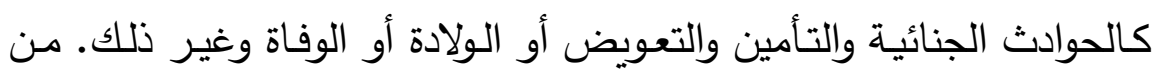

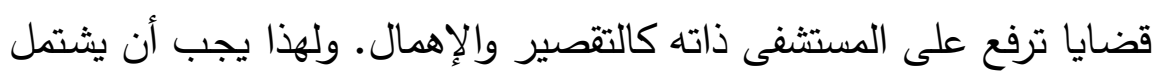
الملف الطبي على معلومات دقيقة مطابقة؛ صيانة للحقوق وحماية للطبيب من المساءلة.

-يعد مـا يحتويـه الملف من المعلومـات الشخصية للمريض سـرا ولا

يجوز إفثاؤه إلا بشروط(')

إذا الإذن الطبي هو جزء من الملف الطبي للمريض ويعد الملف وما يحتويها وثائق للمريض داخل المؤسسة الطبية يمكن الرجوع إليها في كل ما يخص المريض. والله أعلم

* * $\quad * \quad * \quad *$

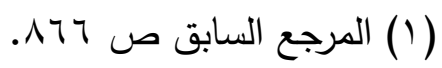




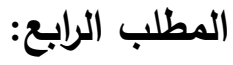 \\ تعريف توثيق الإذن الطبي}

إن المراد بتوثيق الإذن الطبي: هي تلك العملية التي يقوم بها الممارس الصحي أو المنشأة الصحية، بضبط إجراءات ومحتوى الإذن الطبي من خلال الكتابة في ملف المريض أو التسجيل أو التصوير ، وقيدها ليرجع إليها عند الحاجة (').

وأيضًا قيل: هو العملية القانونية الموثقة والتي تتظم طبيًا العلاقة بين المريض والممارس الصحي أو المنشأة العلاجية، وتكون طبقًا للأنظمة واللوائح والاشتراطات الطبية، وتوثيق الإذن الطبي يهدف إلى بيان عناصر الاتفاقية العلاجية المعقودة بين المريض والممارس الصحي أو المنشأة الصحية، ويضمن التوثيق للإذن الطبي الالتزام من الطرفين بالمتقق عليه ضمن العملية الطبية العلاجية غير الطارئة، وبه تحسم مادة النزاع بين الأطراف المتعاقدة موضحا لكل من العاقد والمعقود له ما له وما عليه من واجبات تجاه الإجراء الطبي المتخذ والمحدد مسبقًا، مبينا طريقة التذخل الطبي وآليته ومآلاته ومضاعفاته المحتملة، وتسمى هذه الوثيقة التي تكتب من قبل الممارس الصحي أو المنشأة الصحية في ملف الممريض ب " وثيقة الإذن الطبي " موضحا فيها عنوان الإذن الطبي ().

وعليه فيمكن تعريف توثيق الإذن الطبي بأنه: "الأخذ بجميع الوسائل والإجراءات التي تضبط إذن المريض، وتضمن الحقوق، وتتظم العلاقة بين (1) الدليل الطبي السعودي للإذن الطبي وزارة الصحة السعودية،ط: الأولى

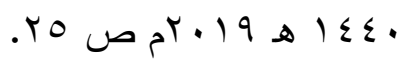

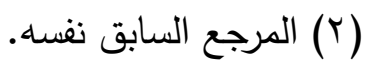




\section{توثيق الإذن الطبي دراسة فقهية مقارنة}

المريض من مقدمي الخدمة الطبية وتوضع في ملف المريض سواء كان

ورقيا أو إلكترونيا ويتم الرجوع إليه عند الحاجة".

شرح التعريف: الأخذ بجميع الوسائل: أي أن يكون لدى جميع

الهيئات الطبية؛ من عيادات ومستشفيات ومختبرات ومعامل وغيرها،

منظومةً كتابية أو إلكترونية لحفظ رضى المريض أو وليه باتخاذ جميع الإجراءات الطبية أو بعضها التي تعمل على علاج المريض.

والإجراءات التي تضبط إذن المريض: تشمل جميع الإجراءات سواء

كان تسجيلا بالكتابة أو التصوير أو التسجيل لإذن المريض أو وليه بالتدخل العلاجي للمريض.

وتضمن الحقوق: المقصود بها حق المريض في المعالجة وحق الطبيب، أو الممارس الصحي والهيئات الطبية في المقابل المتفق عليه. وتنظم العلاقة بين المريض ومقدمي الخدمة الطبية، وتوضع في ملف المريض سواء كان ورقيا أو إلكترونيا ويتم الرجوع إليه عند الحاجة. والله أعلم 


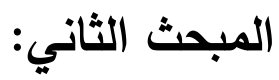 \\ طرق توثيق الإذن الطبي

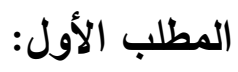 \\ أنواع الإذن الطبي}

للإذن الطبي أنواع متعددة باعتبارات مختلفة، فهو من حيث دلالته ينقسم إلى صريح وغير صريح، وباعتبار طرق التعبير عنه إلى إذن لفظي وإذن بالإشارة، وباعتبار كتابته إلى كتابي وشفهي، ويتتوع باعتبار موضوعه إلى إذن مطلق لأي عمل جراحي يحتاجه المريض (في حالة الخوف من وجود أمراض جراحية قد يفاجأ بها الجراح بعد مباشرته العمل الجراحي) وإذن مقيد لتدخل جراحي محدد('). فإذا كان المقصود من الإذن وجود الرضا والموافقة من المريض على الإجراء الطبي فكل ما يدل على الرضا والموافقة فهو كاف في حصول الإذن.ومعلوم أن التعبير عن الإرادة يكون بعدة طرق الإجراء

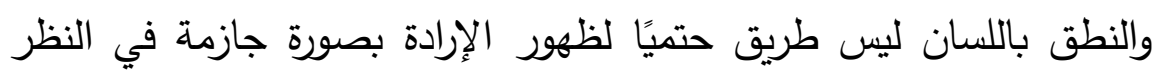
الفقهي، بل النطق هو الأصل في البيان ولكن قد تقوم مقامه وسيلة أخرى مما يمكن أن تعبر عن الإرادة الجازمة تعبيرا كافيا مفيدا(ب). وقد قال شيخ الإسلام ابن تيمية: إن الإذن العرفي في الإباحة أو التمليك أو التصرف بطريق الوكالة كالإذن اللفظي، فكل واحد من الوكالة والإباحة ينعقد بما يدل عليها من قول وفعل، والعلم برضى المستحق يقوم

(1) الإذن في الجراحات المستعجلة د. عصام موسى صه مجلة مجمع الفقه الإسلامي الدورة التاسعة عشرة إمارة الثارقة.

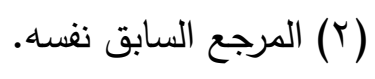




\section{توثيق الإذن الطبي دراسة ققهية مقارنة}

مقام إظهاره للرضىى('). وعليه فلا مانع من اعتبار الأنواع السابقة دالة على الإذن دلالة واضحة(؟). ويدل على اعتبار الدلالة طريقا من طرق التعبير عن الإذن الطبي ما جاء عن عائشة رضي الله عنها أنها قالت: لَدَذنَاهُ(ب)ـ

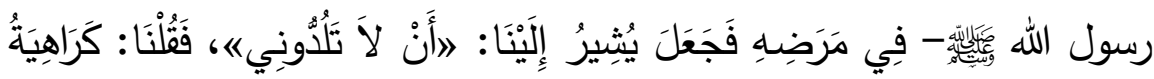

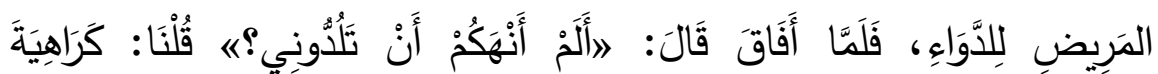

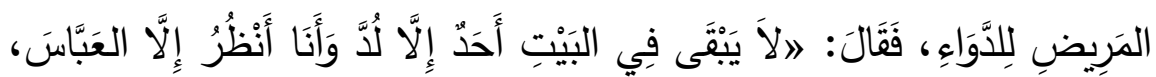

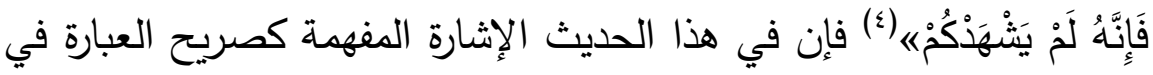
هذه المسألة. وأما السكوت فالأصل أنه لا يعتبر إذنًا، وذلك لقاعدة لا ينسب لساكت قول(0).

\section{المطلب الثاني}

$$
\begin{aligned}
& \text { أنواع توثيق الإذن الطبي. } \\
& \text { التوثيق الطبي نوعان: قانوني رسمي، وعرفي. }
\end{aligned}
$$

التوثيق القانوني: هو أهم أنواع توثيق الإذن الطبي، ويعتبر وثيقة قانونية رسمية، ويجمع في الوقت نفسه بين أحكام الثهادة وأحكام الكتابة.

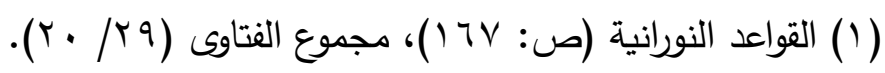

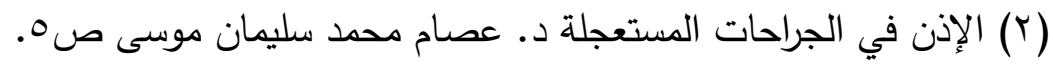

(ץ) (لددناه): جعلنا في جانب فمه دواء بغير اختباره فهذا هو اللاد. صحيح

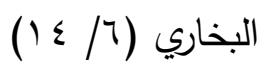

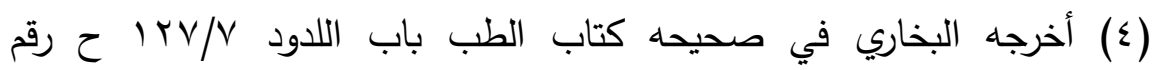

$$
\begin{aligned}
& \text {.(OV, Y) }
\end{aligned}
$$

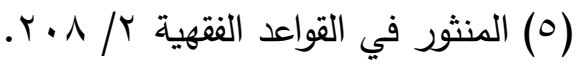


وهذا النظام يخضع لمراقبة المؤسسات الطبية ونظيرتها التشريعية

وإشرافها.

ثانيا التوثيق العرفي أو الشفهي: وهو ما تقوم به الكوادر الطبية أو مؤسساتهم من أعمال شفهية لتوثيق إجراء طبي روتيني يتحتم فعله بمجرد دخول المريض لمرافق المؤسسة الطبية، ويندرج تحت هذا عمل الفحوصات المخبرية، وتلقي بعض التطعيمات.. إلخ، أو غير ذلك من أعمال توثيقية دون أن يتطلب ذلك تدوين من له صلاحية التوثيق وفقا للسياسات

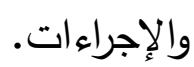

أما الأوراق العرفية: فهي النموذج المعتمد والتي يحررها من لهح صلاحية التوثيق الطبي بصفة رسمية، وتكون مرفقة في صفحات الملف

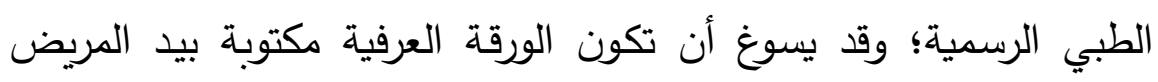
وموقعة منه على أن تكون زائدة وموضحة على نموذج الإذن الطبي الرسمي، ومكتوبة ضمن مذكرات متابعة التقدم المرضي (').

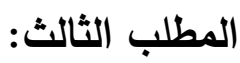
وسائل توثيق الإذن الطبي

$$
\begin{aligned}
& \text { إن طرق التوثيق الثرعية عند الفقهاء أربعة هي: } \\
& \text { 1. التوثيق بالكتابة (البينة الخطية). } \\
& \text { r. التوثيق بالثهادة (البينة الثخصية). }
\end{aligned}
$$

(1) الدليل الطبي السعودي للإذذن الطبي الصادر عن وزارة الصحة السعودية -

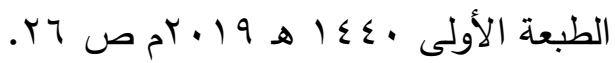




\section{توثيق الإذن الطبي دراسة فقهية مقارنة}

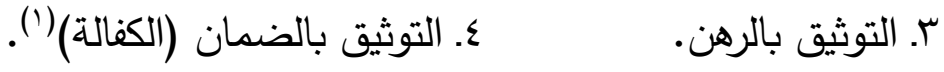

وعليه فإن وسائل التوثيق تنقسم إلى قسمين(r):

1- وسائل يقصد منها الاستيفاء وهي الرهن، والضمان، والكفالة.

r- وسائل يقصد منها إثبات الحق وهي الثهادة، والكتابة.

ومن هذا القسم تتشأ العلاقة بين التوثيق والإثبات(ז)، وتتمثل في

أولا: أن التوثيق مقدم على الإثبات في الوجود، فالتوثيق يكون عند التعامل المقتضي انشغال الذمة بالحق، والإثبات لا يكون بعد إنكار ذلك

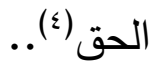

ثانيًا: التوثيق يمثل أحيانا بعض وسائل الإثبات، إلا أن الإثبات

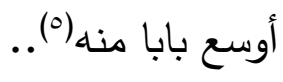

(1) تزوير المحررات دراسة فقهية تطبيقية لعلي الزهراني رسالة دكتوراه بجامعة أم

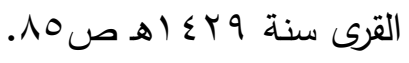

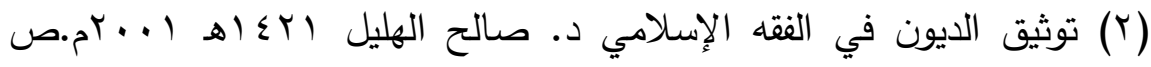

(r) الإثبات: لغة مصدر أثبت بمعنى اعتبر الثيء دائما مستقرا، ويقال: ثبت

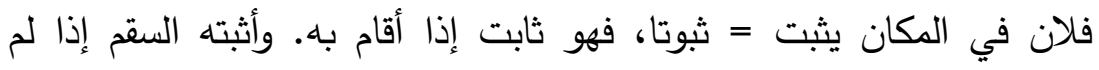

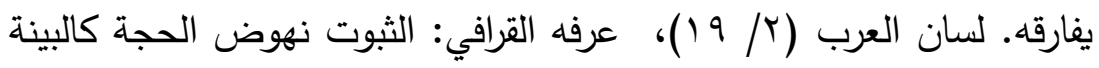

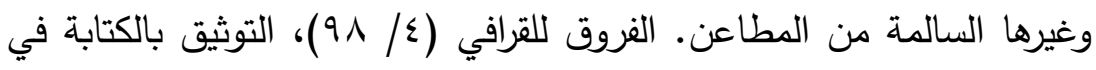

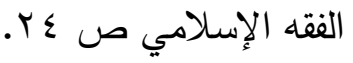

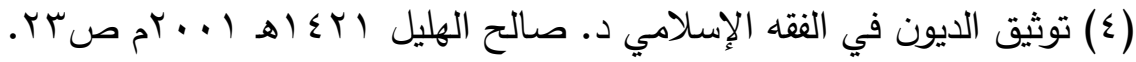

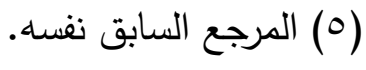


وهذا ما أورده ابن القيم(') في الطرق الحكمية: وهو سبحانه لم يذكر ما يحكم به الحاكم، وإنَّما أرشَّ إلى ما يحفظ به الحق، وطرق الحكم أوسع من الطرق التي تحفظ بها الحقوق(؟). الفرق بين التوثيق والإثبات في أمور :

أولا: من خلال المعنى اللغوي يظهر أن التوثيق أقوى من الإثبات؛ لأن في التوثيق معنى الإحكام والربط والتعاهد والائتمان(汭 بخلا ف الإثبات الذي يعني إقامة المدعي الاليل على ثبوت ما يدعيه قبل المدعى عليه(أ)..

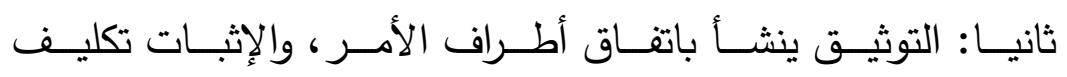

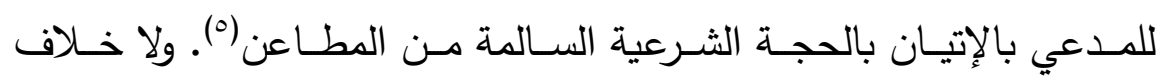
$(v)_{a}$

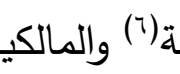

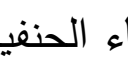
فقه

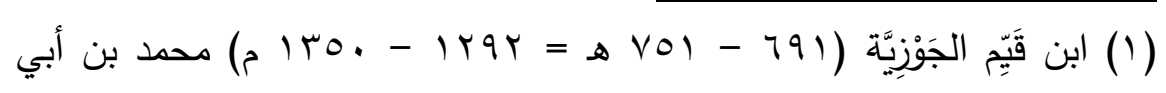
بكر بن أيوب بن سعد الزُّزعي الدمشقيّ، أبو عبد الله، شمس الدين: من أركان

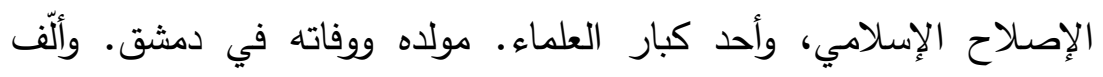

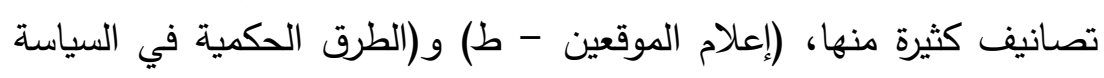

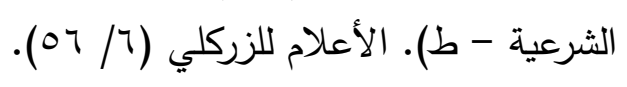

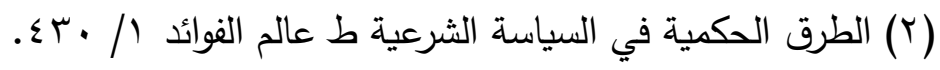

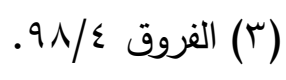

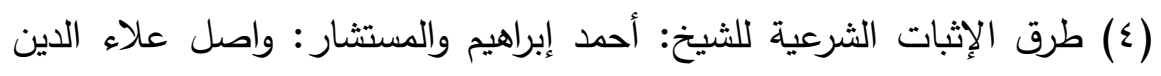

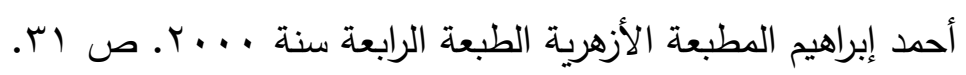

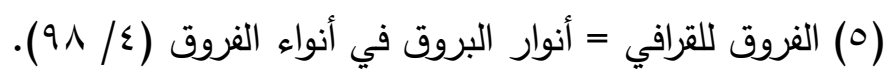

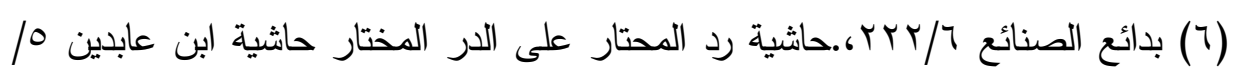
ro 0 . وما بعدها.

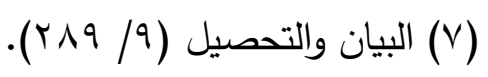




\section{توثيق الإذن الطبي دراسة فقهية مقارنة}

والثـافعية(') والحنابلـة(؟)، في أن الإثبـات يطلـب مـن المـدعي، لمـا رواه

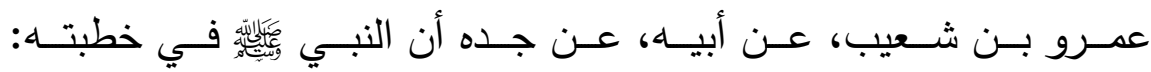

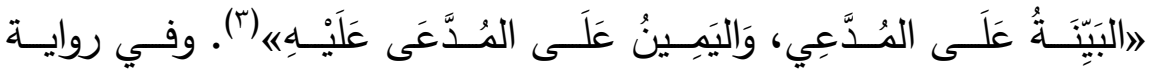

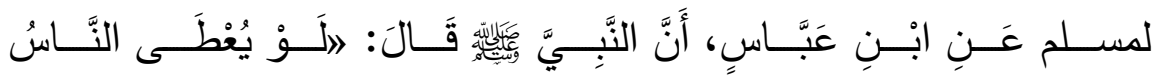

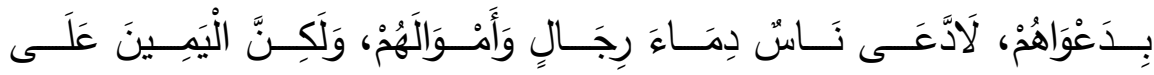

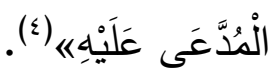
ثالثا: الإثبات يكون بمناسبة تداع أمام القاضي بينما يكون التوثيق في كل حالة يرى ذوو الثأن إحكام الأمر فيها(ن). رابعا: التوثيق والإثبات متغايران في معظم الطرق المؤدية لكل منهما فالتوثيق قد يستمد من طرق أساسها العقد وهو ما يسمى بعقود التوثيقات مثل الرهن والكفالة وتكون بغير العقد كالكتابة والإشهاد...أما الإثبات فلـه طــرق تغـاير أغلبهـا التوثيـق مثـل الإقـرار والثــهادة واليمـين والقـــامة

$$
\begin{aligned}
& \text { (1) نهاية المحتاج ^/ ع اب. }
\end{aligned}
$$

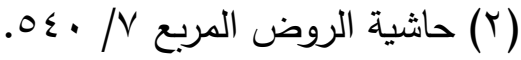

(r) أخرجه الترمذي في السنن كتاب الأحكام، باب ما جاء في أن البينة على المدعي،

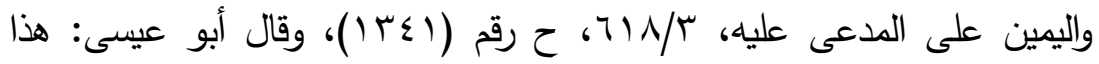
حديث في إسناده مقال ومحمد بن عبيد الله العرزمي يضعف في الحديث من قبل حفظه، ضعفه ابن المبارك، وغيره. وصححه الألباني.

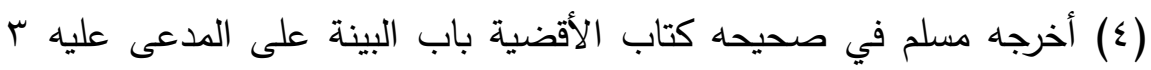

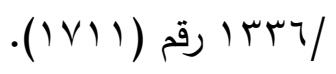

(0) مجلة الأحكام العدلية (ص: ع بr). 
وغيرها..باتفاق بين الفقهاء في الجملة واختلاف في التفاصيل('). وعليه فإن وسائل التوثيق والتسجيل الطبي إما الكتابة أو الثهادة سواء تقليدية خطية ورقية أو إلكترونية تصويرية تسجيلية أو عن طريق الفيديو كونغرانس أو ما يستجد من وسائل حديثة تساير التطور التكنولوجي في كل • عصر

\section{* * $\quad *$ * $\quad *$}

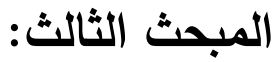

حكم كتابة الوثائق وأهميتها

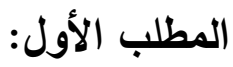 \\ حكم كتابة الوثائق الابق}

يلزم من عرف الوثائق والثروط بيانها لسائلها على حسب ما يلزمه بيان سائر علوم الدين والثريعة وهذا فرض لازم للناس على الكفاية إذا قام به بعضهم سقط عن الباقين، فإن كتابة الوثائق وتعليم الناس إياها من

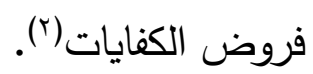

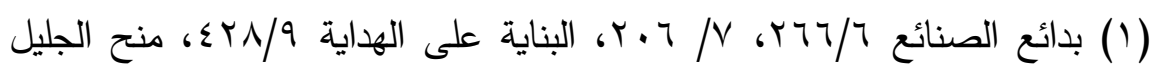


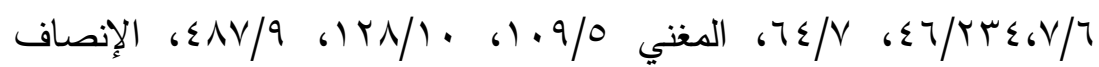
r

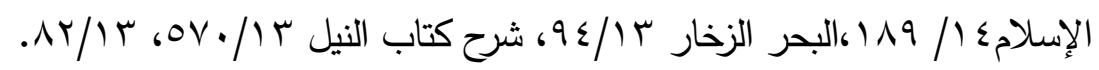

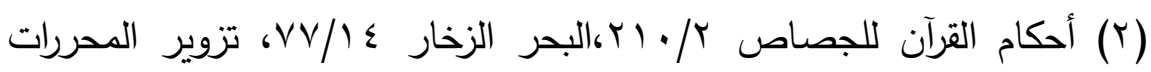




\section{توثيق الإذن الطبي دراسة فقهية مقارنة}

فإن الشريعة جاءت بحفظ حقوق أرباب الحقوق بكل طريق، وسدِّ

الطرق المفضية إلى إضاعتها(')، وتعتبر كتابة الوثائق طريقة من طرق حفظ الحقوق. والوثائق مأمور بها في القرآن(؟)، وحفظ النفس والمال من مقاصد الثريعة الإسلامية التي حرمت الاعتداء عليها ووجوب صيانتها، كما أن وضع القوانين التي تحفظ حقوق الناس وتمنع التظالم من واجبات الحكام، وأول ما يتم النظر فيه هو ديوان الحكم كما قال الماوردي(ّ): "وديوان الحكم هو حجج الخصوم من المحاضر والسجلات وكتب الوقوف؛ لأن الحكام يستظهرون في حفظ الحقوق على أربابها بحفظ حججهم ووثائقهم"(؛).. ونظراً لفساد الذمم وخراب الضمائر وكثرة الفساد في كل المجالات أوجب المشرع القانوني توثيق المعاملات المختلفة، ولذا فقد وضعت وزارة الصحية المصرية في جميع التعاملات الطبية إقرارات بموافقة المريض أو وليه للتذخل العلاجي أو الجراحي؛ مثال ذلك ما صدر عن وزارة الصحة والسكان في شهر يناير الماضي بنشر صورة لإقرار أخذ التطعيم لفيروس ماوس كورونا المستجد، وهو الملحق الأول.

(1) (1) إعلام الموقعين عن رب العالمين 0/ ع ــ ـ.

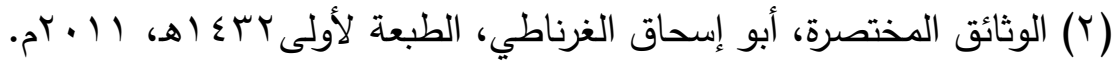

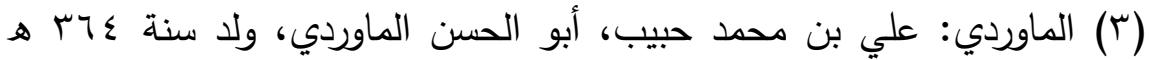
ع Y ₹ م: أقضى قضاة عصره. من العلماء ولد في البصرة، وانتقل إلى بغداد.

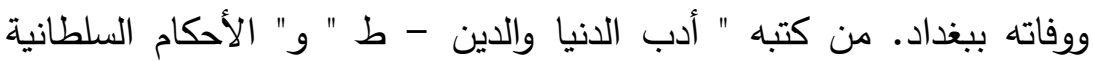

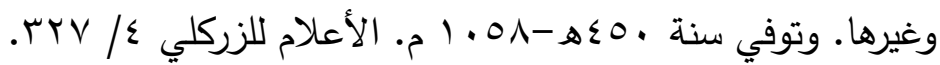

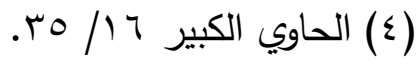




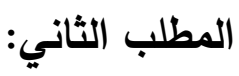

أهمية توثيق الإذن الطبي

تتمثل أهمية توثيق الإذن الطبي فيما يلي:

أولاً: إن الحفاظ على النفس من مقاصد الشريعة الإسلامية، ففي توثيق الإذن الطبي حفاظٌ على النفس، حيث يؤدي الطبيب عمله دون الوقوع الأن تحت أي ضغط نفسي، والآيات التي تدل على المحافظة على النفس كثيرة

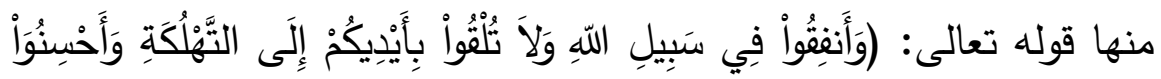

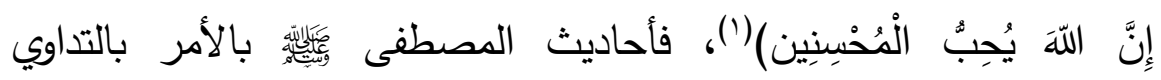
للمحافظة على النفس.

ثانيا: المحافظة على المال وهو ما يستحقه الطبيب من أجرة، حيث إن الإنسان مجبول على حب المال والثح -إلا ما رحم ربي - فإذا قضى إنى مصلحته أنكر إذنه للطبيب، وماطل في سداد الحق مع قدرته عليه، لذا كان توثيق الإذن الطبي هو الفيصل بين الطرفين والإثبات لصاحب الحق منهما.

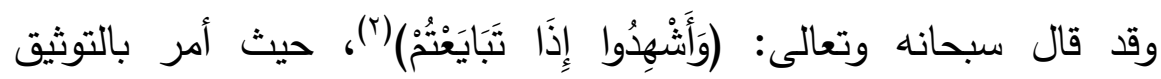
والثهادة على الحقوق فكان ذلك دليلا على مراعاة المال وحفظه، ويعتضد

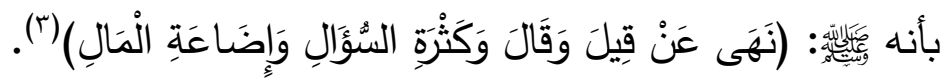
ثالثا: الإنسان مجبول على النسيان والخطأ، وتوثيق الإذن ما هو إلا

$$
\begin{aligned}
& \text { (1) سورة البقرة جزء من آية(190). }
\end{aligned}
$$

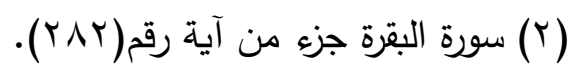

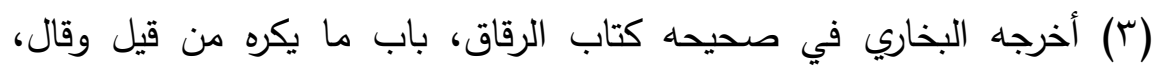

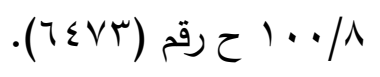




\section{توثيق الإذن الطبي دراسة فقهية مقارنة}

تذكير عند النسيان، وبيان عند الإنكار، وإثبات عند الجحود والنكران. رابعا: المحافظة على الحقوق وأدائها بين الناس والوفاء بالعقود؛ وقد

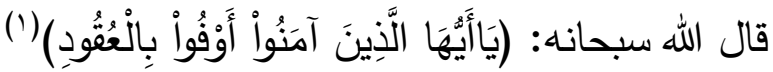

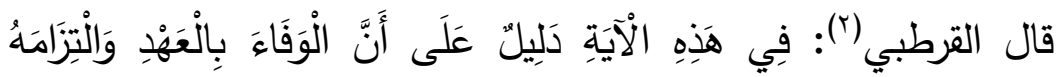

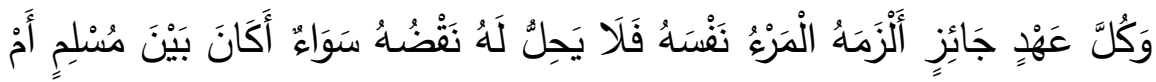

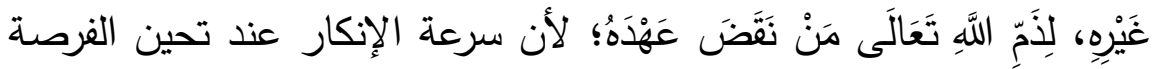

وضعف الضمير لهو طريق الضعفاء (r).

وفي التوثيق بالتسجيل، شهادة أو كتابة(؛) منافع كثيرة من وجوه:

أحدها: صيانة الأموال وقد أمرنا بصيانتها ونهينا عن إضاعتها.

والثاني: قطع المنازعة فإن الوثيقة تصير حكما بين المتعاملين ويرجعان إليها عند المنازعة فتكون سببا لتسكين الفتتة ولا يجحد أحدهما حق صاحبه مخافة أن تخرج الوثيقة وتشهد الثهود عليه بذلك فينفضح أمره بين

(1) سورة المائدة جزء من آية رقم(1).

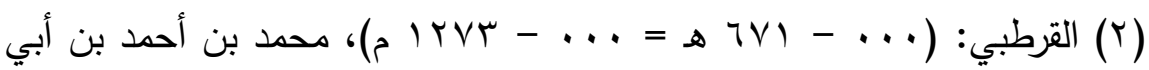
بكر بن فَرُح الأنصاري الخزرجي الأندلسي، أبو عبد الله، القرطبي: من كبار

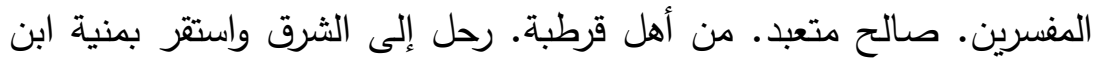
خصيب (في شمالي أسيوط، بمصر) وتوفي فيها. من كتبه " الجامع لأحكام

$$
\begin{aligned}
& \text { القرآن - ط " الأعلام للزركلي (0/ ب r بr). }
\end{aligned}
$$

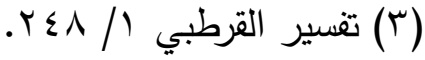

(ع) وفي الموسوعة الفقهية الكويتية (ع ا// هب ):(توثيق بالرهن والكفالة لحفظ الحق). 
والثالث: التحرز عن العقود الفاسدة؛ لأن المتعاملين ربما لا يهتديان إلى الأسباب المفسدة للعقد ليتحرزا عنها فيحملهما الكاتب على ذلك إذا رجعا إليه ليكتب.

والرابع: رفع الارتياب فقد يشتبه على المتعاملين إذا تطاول الزمان مقدار البدل ومقدار الأجل فإذا رجعا إلى الوثيقة لا يبقى لواحد منهما ريبة.وقد ذكر الرازي(') رحمه الله في تفسيره لقوله تعالى: (وَلْيَكْتُب بَّنْنَكُ

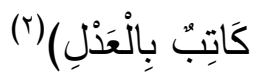
أما قوله بالعدل ففيه وجوه الأول: أن يكتب بحيث لا يزيد في الدين ولا ينقص منه، ويكتبه بحيث يصلح أن يكون حجة لله عند الحاجة إليه. الثاني: إذا كان فقيها وجب أن يكتب بحيث لا يخص أحدهما بالاحتياط دون

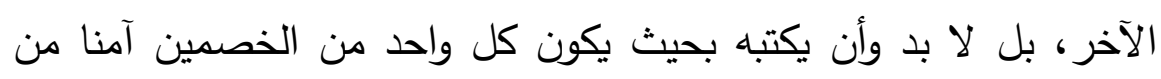
تمكن الآخر من إبطال حقه لآن. $* * \quad * * *$

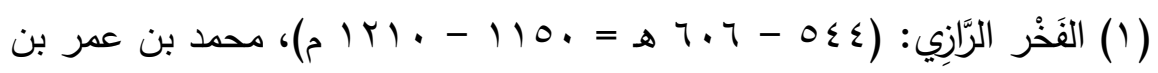
الحسن بن الحسين التيمي البكري، أبو عبد الله، فخر الدين الرازيّ: الإمام المفسر • أصله من طبرستان، ومولده في الري وإليها نسبته، ، وتوفي في هراة. وكان يحسن الفارسية. من تصانيفه (مفاتيح الغيب - ط) ثماني مجلدات في في ولئي

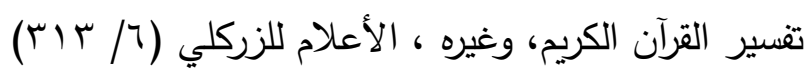

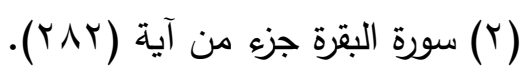

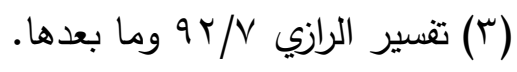




\section{توثيق الإذن الطبي دراسة فقهية مقارنة}

\section{المبحث الرابع:}

\section{شروط الموثق والإذن الطبي}

الوثائق لها شأن عظيم، فبها تحفظ الحقوق ويقطع التنازع، ونظراً لأهميتها فقد وضع الفقهاء رحمه الله شروطًا لمحرر الوثيقة؛ حتى تكون تلك الوثيقة معتبرة والقائم بها قادر على القيام بمهامها، وسأذكر هذه الشروط في المطالب الآتية وهي كما يلي:

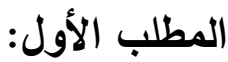

\section{إسلام الموثق}

اختلف الفقهاء في إسلام محرر الوثيقة إلى قولين: القول الأول:

ذهب جمهور الفقهاء من الحنفية(') والمالكية(r) والشافعية في المشهور (r)،

والحنابلة(؛)، ووافقهم الثيعة الإمامية(0)، والإباضية(†) إلى أن الكاتب لابد أن يكون مسلما ولا يجوز كونه غير مسلم.

القول الثاني: ذهب المالكية(`) والثافعية في أحد الوجهين(^) إلى أنه

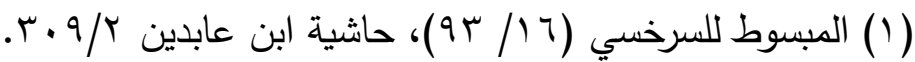

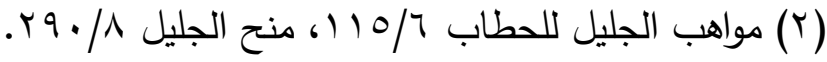

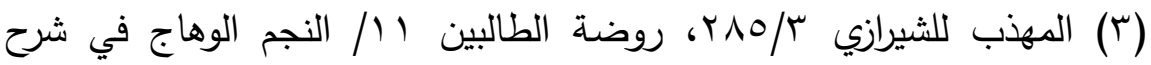

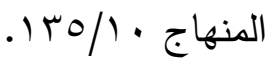

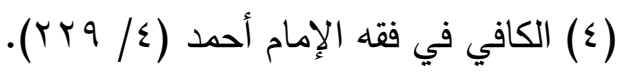

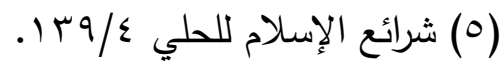

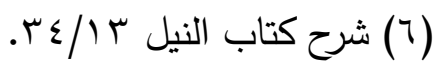

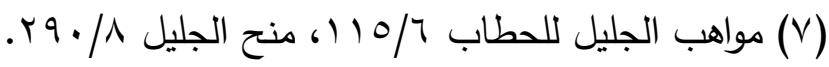

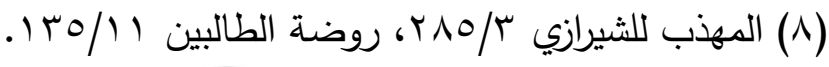


يستحب أن يكون الموثق مسلما.

\section{الأدلة: أدلة أصحاب القول الأول:}

استذل الجمهور على اشتراط إسلام محرر الوثيقة بما يلي:

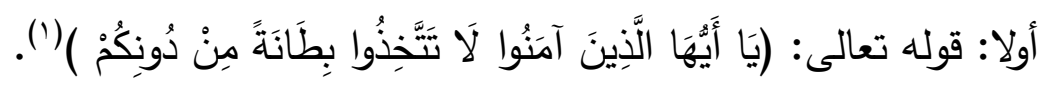

وجه الدلالة: تدل الآية الكريمة دلالة واضحة على أنه لا يجوز

استكتاب أهل الذمة، ولا غير ذلك من تصرفاتهم في البيع والثراء والاستتابة إليهم(r)، فقد نهى تعالى عباده المؤمنين أن يتخذوا بطانة من المنافقين من أهل الكتاب وغيرهم يظهرونهم على سرائرهم أو يولونهم بعض الأعمال

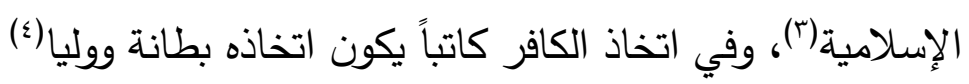

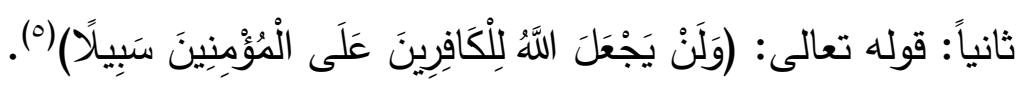

وجه الدلالة: إن الكافر ليس من أهل الولاية على المسلم، وقد قطع الثرع ولاية الكافر على المسلمين، كما أن إثبات الولاية للكافر على المسلم

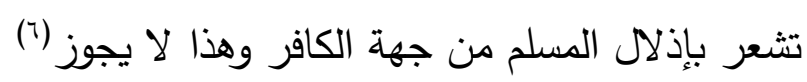

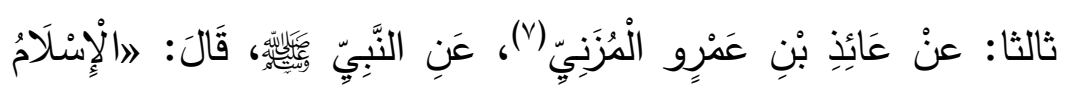

$$
\begin{aligned}
& \text { (1) سورة آل عمران آية رقم (1) (1). }
\end{aligned}
$$

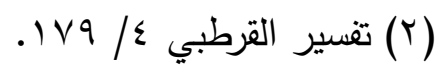

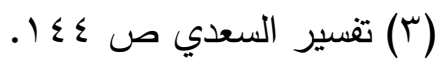

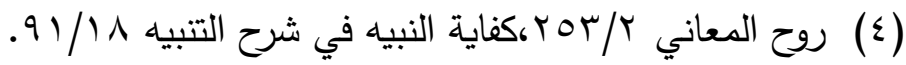

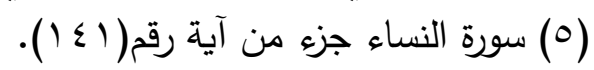

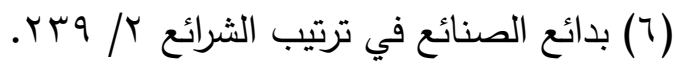

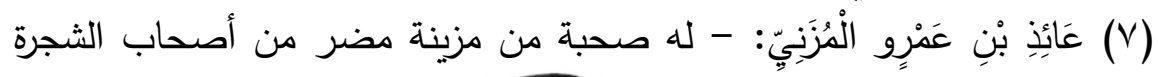


(1) يَعْلُو وَلَا يُعْلَى

وجه الدلالة: يدل هذا الحديث دلالة صريحة على عدم تولي الكافر ولاية على المسلم؛ وفي التوثيق علو على المسلمين وهذا لا يكون. قال السرخسي(؟): لعلو حال الإسلام لا تثبت هذه الولاية للكافر، ويقصد بها ولاية

الإرث ولا مانع من حمل التوثيق عليها ().

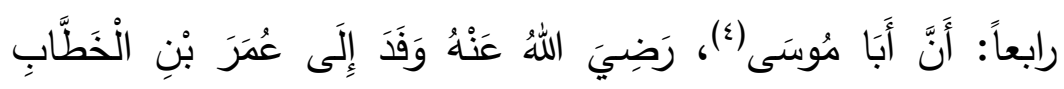

يقال له الأشج العبدي مات في إمارة يزيد بن معاوية بالبصرة وصلى عليه أبو

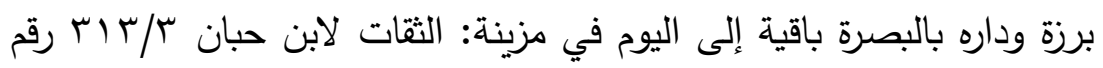
(1.11)

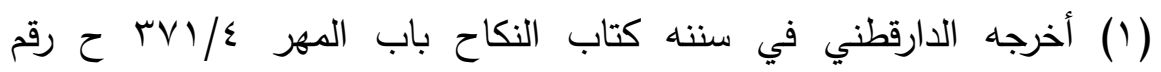

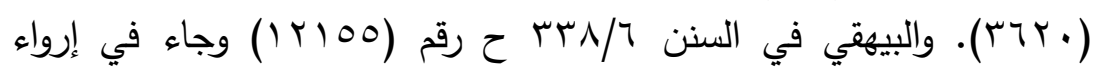

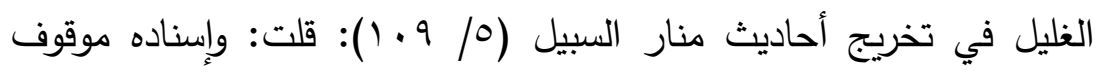
صحيح، وعلقه البخارى حسن مرفوعا بمجموع طريقى عائذ ومعاذ، وصحيح موقوفا والله أعلم

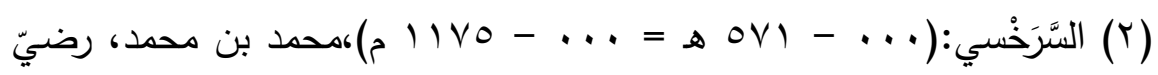

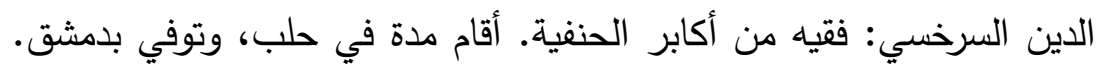

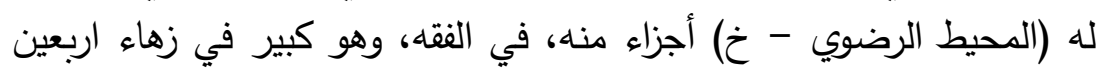

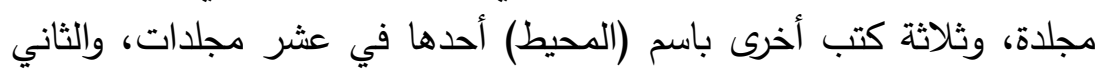

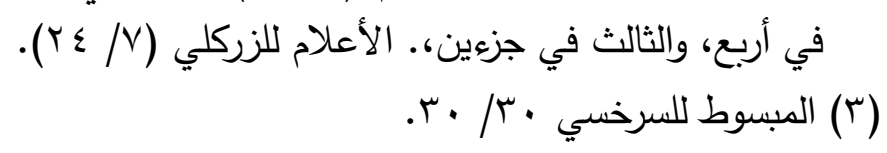

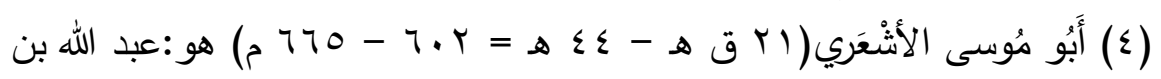

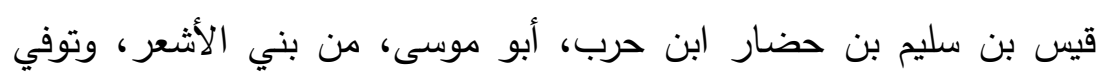

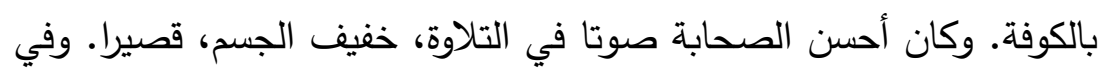

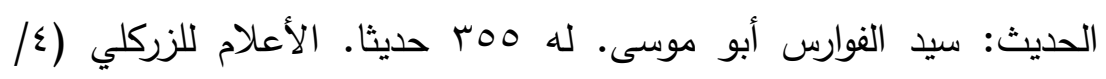




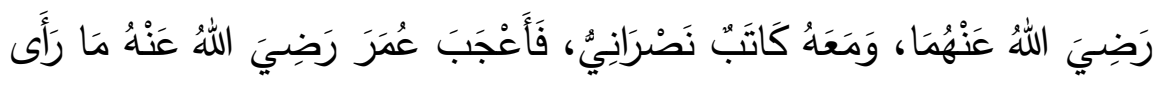

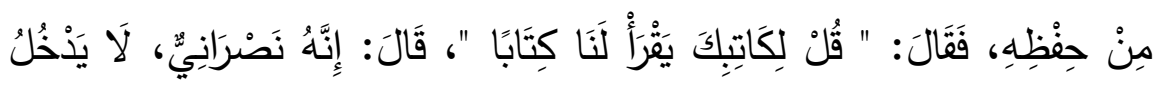

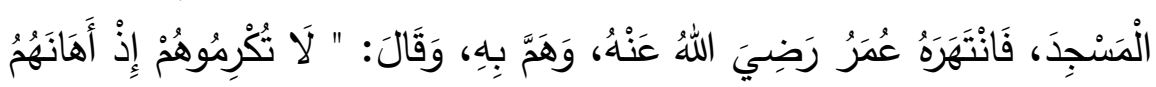

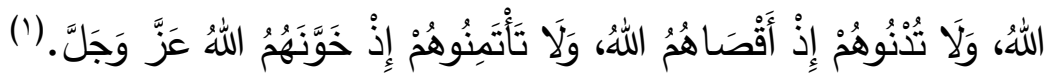
وجه الدلالة: أنَّ نهُرَ أميرِ المؤمنين عمرَ ابن الخطاب رضي الله عنه

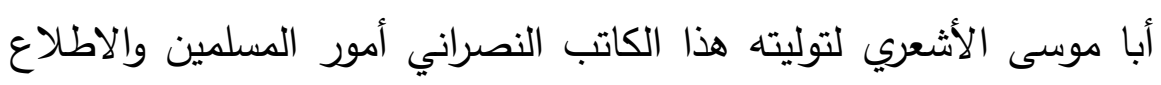
عليها يدل على وجوب اشتراط إسلام من يتولى كتابة أمور المسلمين.

خامسًا: أن الإسلام من شروط العدالة، والعدالة شرط في الكاتب(؟) سادسًا: لا يجوز أن يستكتب ذمياً؛ لأنهم خرجوا بفسقه في الدين عن

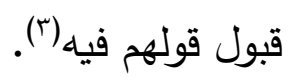
سابعًا: ولقول الثافعي - رحمه الله تعالى -: وما ينبغي عندي لقاض، ولا لوال من ولاة المسلمين أن يتخذ كاتبا ذميا، ولا يضع الذمي في موضع يتفضل به مسلما. وينبغي أن نعرف المسلمين بأن لا يكون لهم

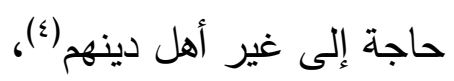
ثامنًا: ولأنه لا تجوز شهادة أهل الذمة على المسلمين في قليل أو (1) السنن الكبرى للبيهقي، كتاب أدب القاضي، باب لا ينبغي للقاضي ولا للوالي

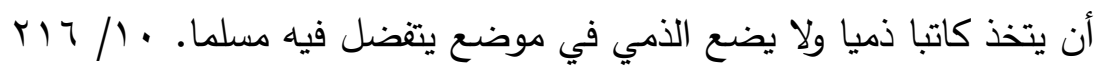

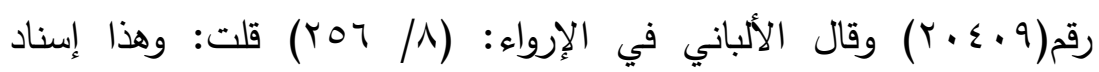

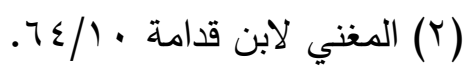

$$
\begin{aligned}
& \text { (r) الحاوي الكبير } 79 \text { 19/1. } \\
& \text { (ع) الأم للشافعي TrV/T. }
\end{aligned}
$$




\section{توثيق الإذن الطبي دراسة فقهية مقارنة}

كثير (') فكذا لا يكن منهم ولاية التوثيق.

تاسعًا: ولأن كاتب القاضي يعظم في الناس، وقد نهينا عن

تعظيمهم(r)؛ لأن الكاتب ينوب عن القاضي فيما هو من أهم أعماله فلا يختار لذلك إلا من يصلح للقضاء وربما يحتاج القاضي إلى الاعتماد على شهادته في بعض الأمور، أو يحتاج بعض الخصوم إلى شهادته فلا يختار

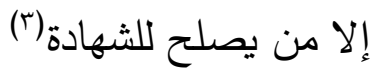

عاشرا: أجمع كل من يحفظ عنه من أهل العلم أن الكافر لا ولاية له على مسلم بحال.()؛ولأن الكافر عدو للمسلمين فلا يؤمن أن يكتب ما يبطل باه حقوقهم (ن) أدلة أصحاب القول الثاني: استدل أصحاب القول الثاني القائلون باستحباب إسلام محرر الوثيقة بما يلي: الدليل الأول: أن ذلك يستحب لأن ما يكتبه لا بد أن يقف عليه

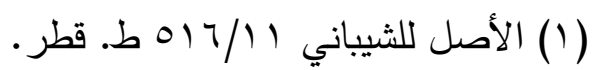

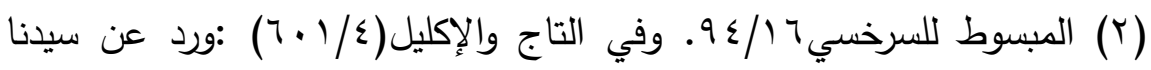
عمر - رضي الله عنه -: (أذلوهم ولا تظلموهم) .مجموعة الرسائل والمسائل

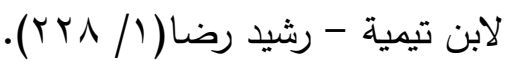

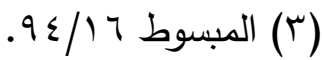

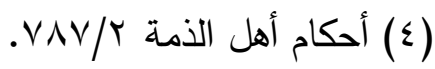

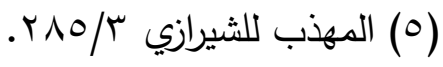


القاضي ثم يمضيه فيؤمن فيه من الخيانة(').

نوقش ذلك: بأنه قد يغفل القاضي عن قراءة ما يكتبه أو يقرؤه(؟). الدليل الثاني: لأن الكاتب يستشار وغير المسلم ليس من أهل المشورة قال مالك: لا يستكتب النصراني لأن الكاتب يستشار والنصراني لا يستشار في المسلمين. قال: ولا يستكتب القاضي إلا عدلا مسلما مرضيا؟َ". نوقش ذلك: بأن التوثيق في زماننا هيئة مستقلة عن القضاء، فلا يتحقق استثارة القاضي للموثق في ذلك ولكن وثيقته يعتمد عليها في الدلالة

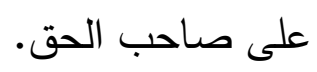

الدليل الثالث: إن احتمال التزوير من غير المسلم قائم؛ لاطلاعه على

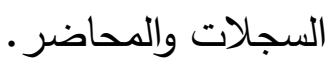

يمكن أن يجاب عليه: بأن هذا راجع لفساد الذمم والأخلاق في المسلمين وغيرهم.

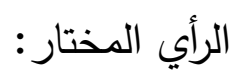

بعد عرض أقوال الفقهاء وأدلتهم والمناقشة، يتبين لي - والله أعلم أن الرأي المختار ما ذهب إليه أصحاب القول الأول؛ وهو عدم جواز تولي غير المسلمين مهنة الكتابة والتوثيق إلا عند الاضطرار وذلك لما يلي: أولاً: لقوة أدلتهم وسلامتها من المعارضة.

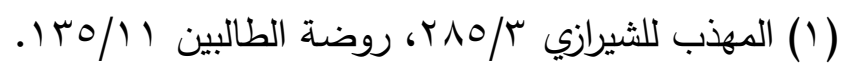

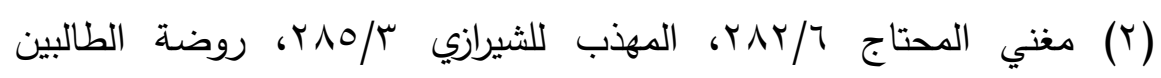
$.110 / 11$

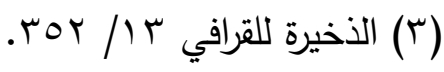




\section{توثيق الإذن الطبي دراسة فقهية مقارنة}

$$
\text { والجواز عند الإضطرار لما يلي: }
$$

أولاً: أن تلك المهنة منضبطة بضوابط وأنظمة تحكمها القوانين في

$$
\text { الحكومة المصرية وغيرها. }
$$

ثانيًا: أن النظام الإكتروني والتحول الرقمي في سائر المعاملات يضبط كثيرا من الغش والتلاعب والتزوير في الوثائق العامة. ثالثًا: أن الدستور المصري الذي يحكم العلاقات بين الدولة وأفرادها يحقق مبدأ المساواة بين الجميع.

\section{* * $\quad * \quad * \quad *$ \\ المطلب الثاني : - المبان \\ البلوغ والعقل}

اتفق الفقهاء(') على أن الموثق لابد أن يكون مكلفاً أي بالغا عاقلا في جميع المعاملات ، ونظرا للمسؤولية الملقاة على عاتق الموثق فهل يحتاج إلى العقل الذي يكلف به الإنسان وهذا لا شك في اشتراطه أم أنه يحتاج إلى ذكاء عقل، وسرعة بديهة وإدراك لما وراء الأشياء وحسن استدلال ووصول. لذا نجد الفقهاء رحمهم الله قد اختلفوا في اشتراط وفرة العقل في الموثق إلى

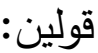

$(r)$ (r)

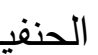

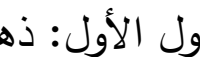

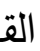

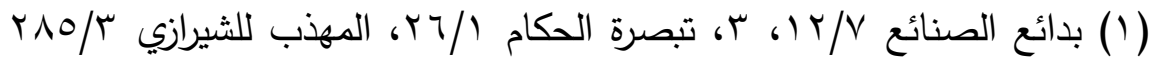

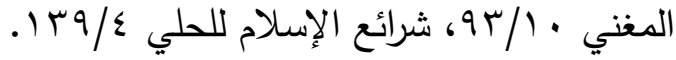

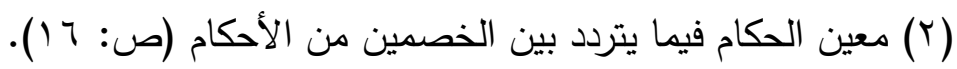

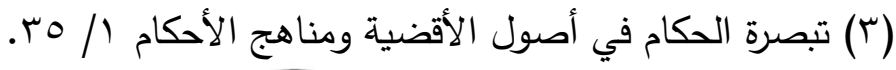


والثـافعية (') والحنابـــة(r)، ووافقهـم الثــيعة الإماميـة(r) إلـى اشـترط العقـل

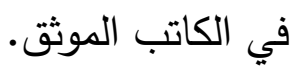

القول الثاني: ذهب بعض المالكية(£) والثافعية(0) إلى اشتراط وفورة العقل في الكاتب الموثق.

وجاء في عجالة المحتاج إلى توجيه المنهاج في شروط الكاتب:

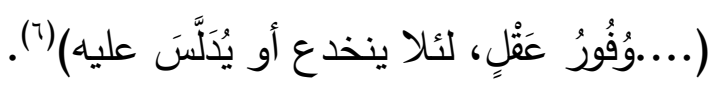
الأدلة:

أدلة القول الأول: استدل أصحاب القول الأول على اشتراط أن يكون

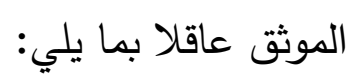

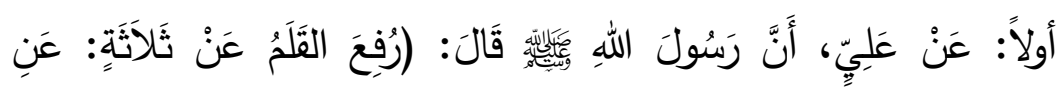

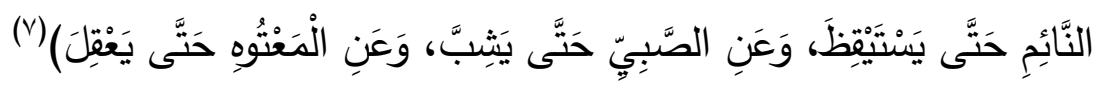

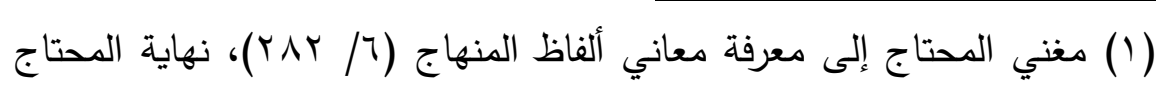
.ror/A

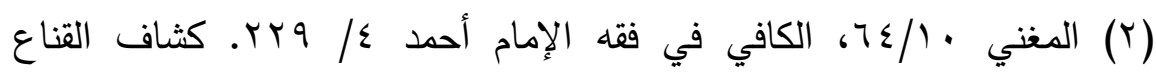

$$
\begin{aligned}
& \text { ( / / }
\end{aligned}
$$

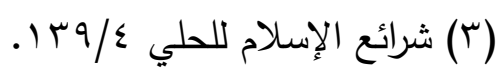

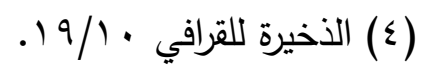

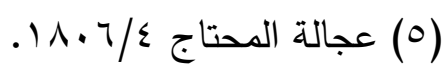

$$
\begin{aligned}
& .11 .7 / \varepsilon(7)
\end{aligned}
$$

أخرجه الترمذي في سننه كتاب الحدود باب ما جاء فيما يجب عليه الحد (V)

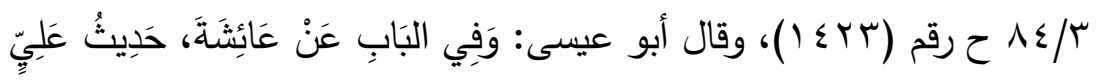
حَدِيثٌ حَسَنْ غَرِيْبٌ مِنْ هَذَا الوجهاه. 


\section{توثيق الإذن الطبي دراسة فقهية مقارنة}

وجه الدلالة: أن العقل شرط التكليف والموثق موضوع للخدمة العامة، فكيف للموثق أن يكون غير عاقل وليس له مصلحة في نفسه بل يحتاج إلى غيره!

الدليل الثاني: التوثيق ولاية ولا يلي أمر المسلمين إلا صاحب عقل ورأي، فإن كان بغير فكيف يلي أمر المسلمين!

أدلة القول الثاني: استدل أصحاب القول الثاني على أن المراد بالعقل

$$
\text { في الموثق وفرته وحسن فطنته بما يلي: }
$$

الدليل الأول: أن الموثق لابد أن يكون سريع البديهة وقوي الملاحظة يستطيع فهم ما وراء الأمور ؛ ليستطيع تمييز صحة وخطأ ما يسجله. الاليل الثاني: وقوع كثير من المشكلات في كثير من العقود الموثقة؛

$$
\text { بسبب الغفلة وعدم الدارية وسرعة الانخداع (') }
$$

بعد عرض آراء الفقهاء وأدلتهم يظهر لي أن القول المختار ما ذهب إليه جمهور الفقهاء وهو أن الموثق لابد أن يكون له صفات خاصة؛ ومنها وفرة العقل وسرعة إدراكه، وليس العقل فقط الذي هو مناط التكليف؛ وذلك لما يلي:

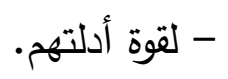

- ولأن القوي العقل سريع البديهة يصل إلى ما لا يصل إليه غيره فيستطيع التمييز بين الصواب والخطأ عند كتابة الوثائق.

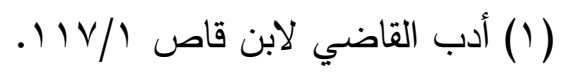


- يستطيع صاحب وفورة العقل أن يحسن التصرف فيما يعرض له

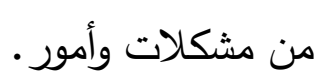

- يستطيع التمييز بين صاحب الحق وغيره في توثيق البيانات

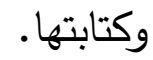

\section{المطاب الثالث \\ عدالة(1) الموثق}

اختلف الفقهاء في عدالة الموثق إلى قولين:

القول الأول: ذهب الحنفية(r) والمالكية(r) والثافعية())، ووافقهم الثيعة

$$
\text { الإمامية(ه) والإباضية(؟) إلى أن العدالة شرط في الموثق. }
$$

القول الثاني: ذهب بعض المالكية(V)، والثافعية في وجه(^)(الحنابلة(9)

(1) العدالة في اللغة: الاستقامة، وفي الثريعة: عبارة عن الاستقامة على طريق

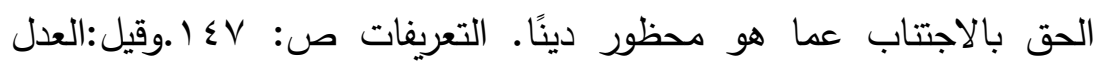
مصدر بمعنى العدالة وهي الاعتدال والثبات على الحق. الحدود الأنيقة

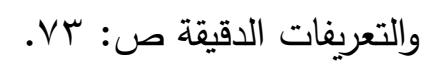

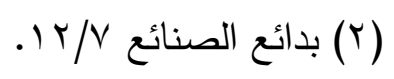

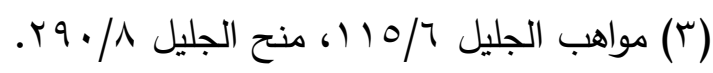

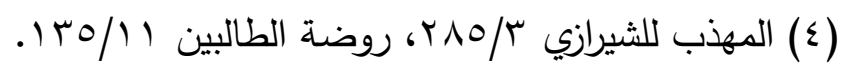

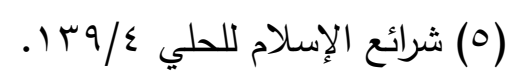

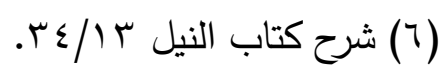

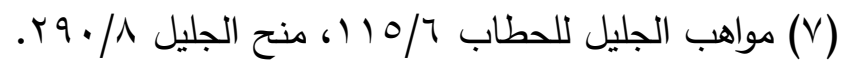

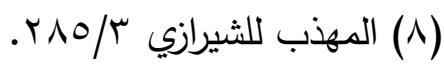

$$
\begin{aligned}
& \text { (9) المغني • (9/1) }
\end{aligned}
$$




\section{توثيق الإذن الطبي دراسة فقهية مقارنة}

إلى أن العدالة مستحبة في الموثق.أدلة القول الأول:

استدل أصحاب القول الأول على اشتراط العدالة في الموثق بما يلي:

الدليل الأول: قوله تعالى : (وَلْيَكْتُبْ بَيْنَكُمْ كَاتِبْ بِالْعَدْلِ)( (')

وجه الدلالة: تتص الآية الكريمة على أن كاتب الوثائق لابد أن يكون

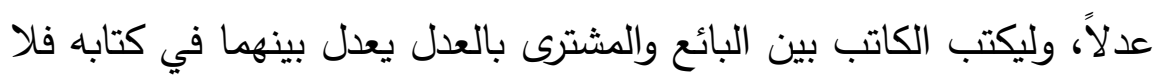

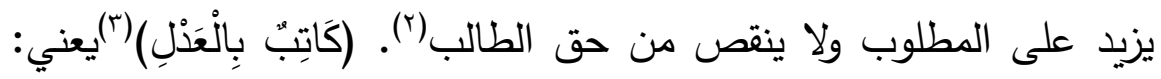
بالحق والإنصاف في الكتاب الذي يكتبه بينهما، بما لا يحيف ذا الحق حقه، ولا يبخسه، ولا يوجب لله حجة على من عليه دينه فيه بباطل، ولا يلزمه ما

ليس عليه(£)

وقال القرطبي (0): الباء في قوله تعالى" بالعدل" متعلقة بقوله:" وليكتب"

وليست متعلقة ب" كاتب" لأنه كان يلزم ألا يكتب وثيقة إلا العدل في

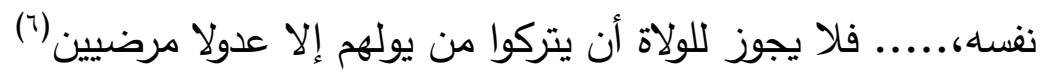

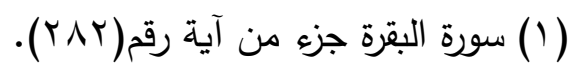

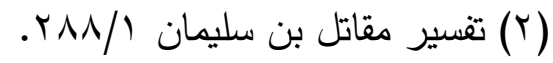

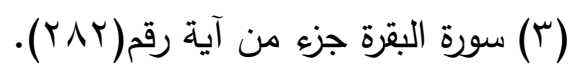

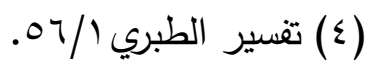

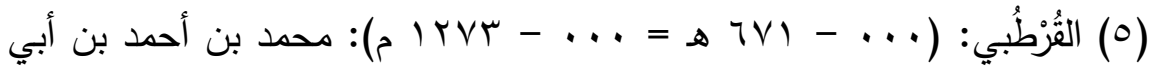

بكر بن فَرُح الأنصاري الخزرجي الأندلسي، أبو عبد الله، القرطبي: من كبار

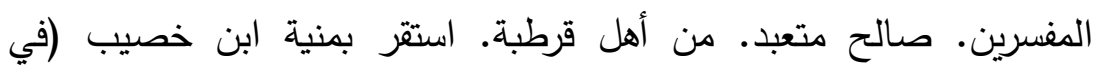

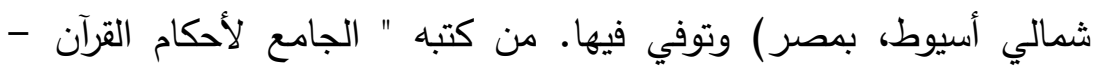

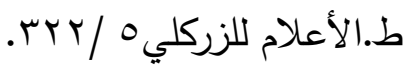

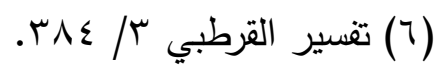


وفي الآية أمر لمن تولى كتابة الوثائق بين الناس أن يكتبها بالعدل

بينهم، والكتاب وإن لم يكن حتما فإن سبيله إذا كتب أن يكتب على حد العدل والاحتياط والتوثق من الأمور التي من أجلها يكتب الكتاب بأن يكون شرطا صحيحا جائزا على ما توجبه الثريعة (1)

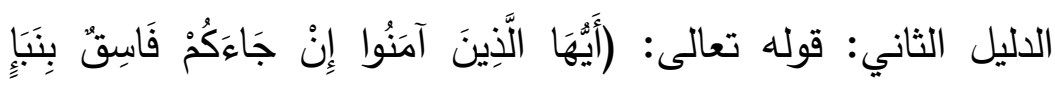

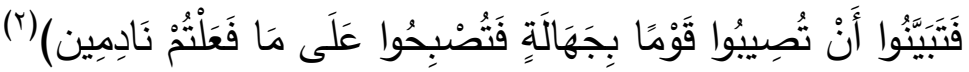

وجه الدلالة: تدل الآية الكريمة على أن الفاسق لا يقبل خبره، ولا النبأ

الذي يأتي به، والمقصود هنا الإشارة إلىى قوله تعالى: (إِنْ جَاءَكُمْ فَاسِقُّ بِنَبَاٍ

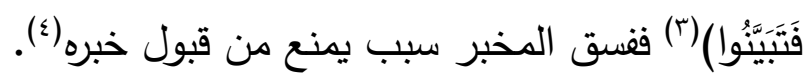

الاليل الثالث: ولا يجوز أن يكون فاسقا لأنه لا يؤمن أن يخون (०). وقد قال الإمام مالك -رحمه الله تعالى -: لا يكتب الوثائق بين الناس إلا عارف

$$
\begin{aligned}
& \text { بها عدل في نفسه مأمون(؟). } \\
& \text { أدلة القول الثاني: }
\end{aligned}
$$

استدل القائلون باستحباب عدالة الموثق بما سبق أن استدل به

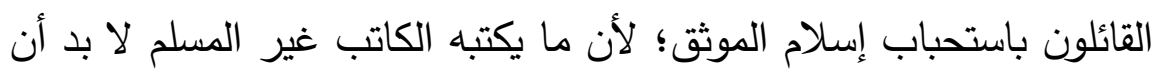

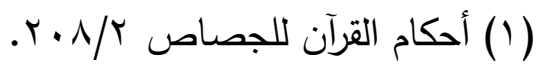

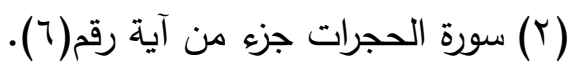

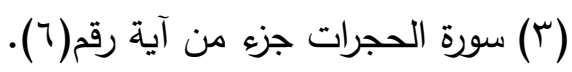

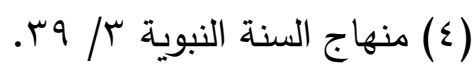

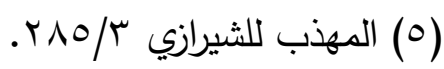

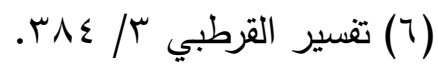




\section{توثيق الإذن الطبي دراسة فقهية مقارنة}

يقف عليه القاضى ثم يمضيه فيؤمن فيه من الخيانة('). وقد سبقت مناقشته هناك فلا داعي للتكرار • - من

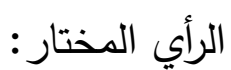

بعد عرض أقوال الفقهاء وأدلتهم يتبين لي أن الرأي المختار ما ذهب إليه أصحاب القول الأول وهو اشتراط العدالة في الموثق وذلك لما يلي: أولاً: لقوة أدلتهم وسلامتها.

ثانياً: تولية الفاسق شبهة وفساد بين حقوق الرعية مما يؤدي إلى المنازعات.

ثالثاً: في تولية الفاسق فتح لباب الرشاوي والمحسوبية على مصراعيه بسبب خراب الذمم وفساد الأخلاق.

وتكون حسب الإمكان وقال القرافي: إذا لم نجد في جهة إلا غير العدول أقمنا أصلحهم وأقلهم فجورا للشهادة عليهم ويلزم مثل ذلك في القضاة وغيرهم فلا نضيع المصالح. قال وما أظن أحدا يخالفه في هذا، فإن التكليف شرط في الإمكان وهذا كله للضرورة، لئلا تنهر الدماء وتضيع الحقوق وتتعطل الحدود (r).

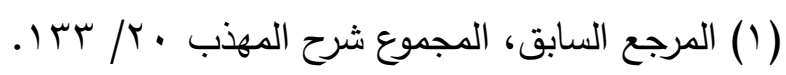

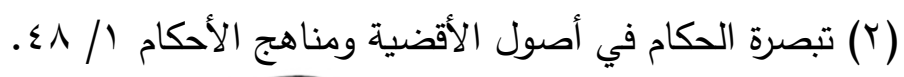




\section{المطلب الرابع: - (ابع}

\section{العلم بفقه الوثيقة}

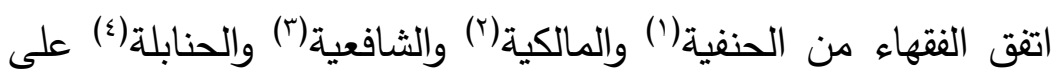
أنه لا يكتب الوثائق إلا العارف هن

فقد قال الجصاص عند تفسيره لآية المداينة: " ولأن الكاتب بذلك إذا إلا كان جاهلا بالحكم لا يأمن أن يكتب ما يفسد عليهما ما قصداه ويبطل ما تعاقداه"() وقد قال مالك رضي الله عنه: " لا يكتب الوثائق بين الناس إلا

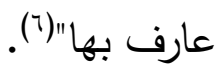

قال الثافعي: " ولا ينبغي أن يتخذ كاتبا حتى يجمع أن يكون عدلا

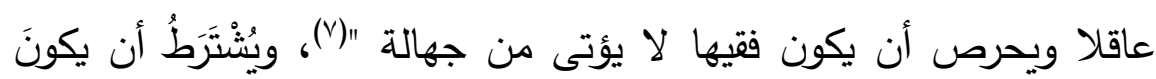

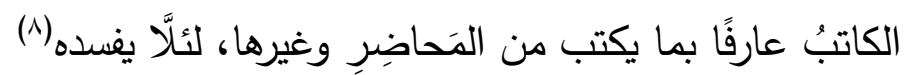
ويستحب أن يكون فقيها؛ ليعرف مواقع الألفاظ، ويفرق بين الجائز

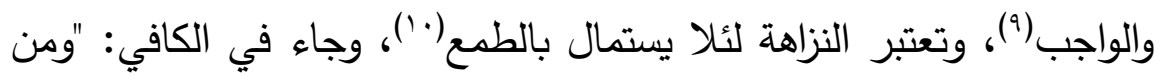

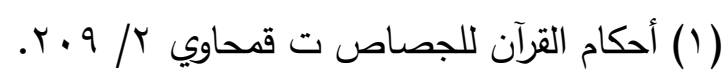

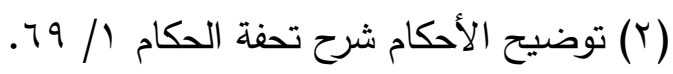

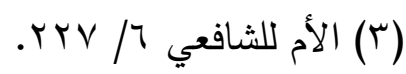

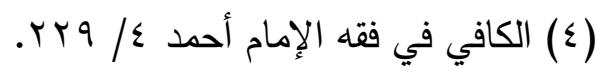

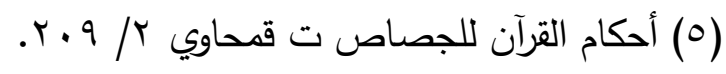
(7) توضيح الأحكام شرح تحفة الحكام / / (79)

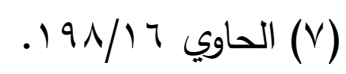

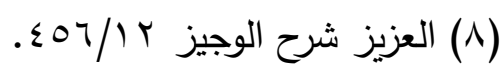

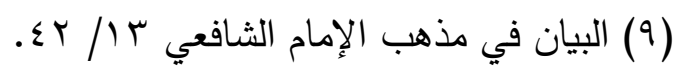

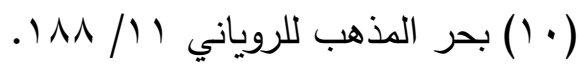




\section{توثيق الإذن الطبي دراسة فقهية مقارنة}

شرط الكاتب أن يكون عارفًا بما يكاتب به القضاة من الأحكام. وما يكتبه

من المحاضر ، والسجلات؛ لأنه إذا لم يعرفه، أفسد ما يكتبه بجهله"( (1).

$$
\begin{aligned}
& \text { * } \quad * \quad * \quad * * \\
& \text { المطلب الخامس: } \\
& \text { شروط الإذن الطبي } \\
& \text { يشترط في الإذن الطبي عدة شروط: }
\end{aligned}
$$

أولا: أن يكون الإذن صادرا ممن له الحق في الإذن وكان أهلا(؟)

لإصداره بأن يكون المريض بالغا عاقلا (مكلفا) قائما على أمر نفسه' وإلا فوليه، فإذا صدر الإذن من غير أهله بأن كان المريض غير بالغ أو غير عاقل فلا يعتد به عليه(ז)، أو كان فاقدا للأهلية بأن كان مجنونا أو صغيرا

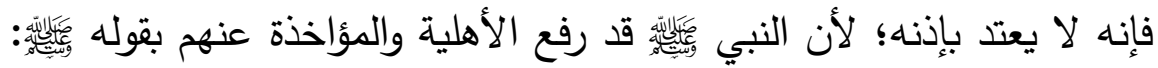
(رفع القلم عن ثلاث....)(؛) وانتقل الإذن إلى وليهما. وقد قال ابن القيم:

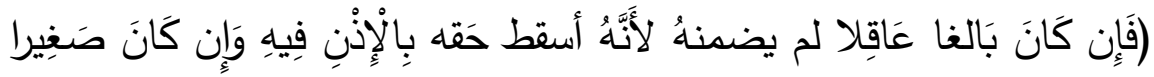

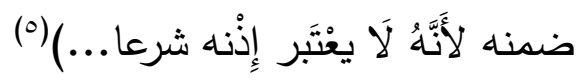

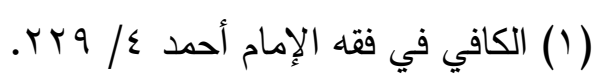

(r) الأهلية: عبارة عن صلاحية لوجوب الحقوق المشروعة له وعليه. التعريفات

$$
\text { الفقهية (ص: و بr). }
$$

(r) المدخل الفقهي العام د. مصطفى الزرقاء. ط. دار القلم دمشق - الثانية

$$
\text { . } \wedge \leqslant q / 1, r . . \varepsilon-1 \leqslant r 0
$$

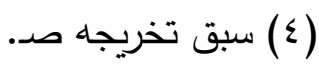

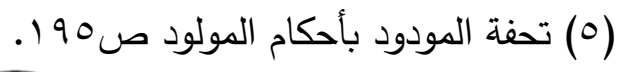


فأشار رحمه الله إلى أن الإذن لابد أن يصدر من بالغ عاقل، فإذا صدر من الصغير والمجنون فلا يعتد به. وقد جاء في قرار هيئة كبار

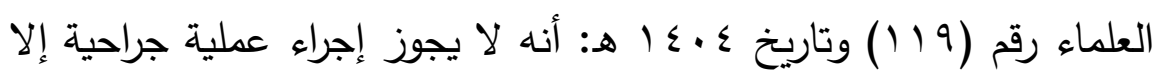
بإذن المريض البالغ العاقل سواء كان رجلا أم امرأة، فإن لم يكن بالغا عاقلا

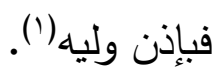

فلابد في الثخص الذي يأذن بالإجراء الطبي أن تتوفر فيه أهلية الإذن به، حتى يحكم باعتبار إذنه، ويستوي في ذلك المريض نفسه أو لإنراء

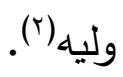

ثانيا: أن يكون المأذون به مشروعا: بأن يكون الإجراء الطبي الذي

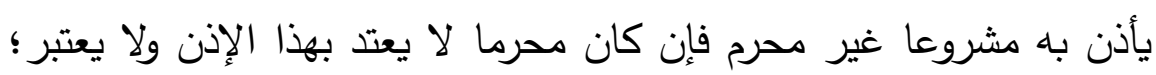
وذلك لأن إباحة المباشرة لجسم المريض من الطبيب إنما تكون لمعالجته وجلب مصلحته لا للإضرار به أو إجراء ما هو محرم شرعا له (). ثالثا: أن يكون الإذن محددا: كأن يقول المريض للطبيب أذنت لك بفعل ما شئت لعلاجي فقد ذهب بعض الباحثين المعاصرين إلى أنه إذن إند معتبر شرعا، لأنه لا فرق في الإذن على وجه الإطلاق أو على وجه التقييد

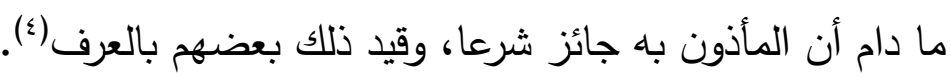

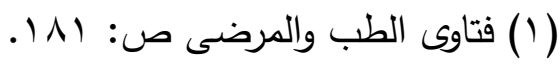

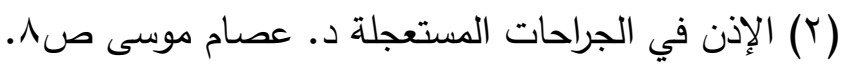

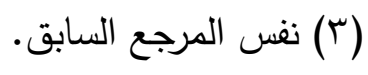
(ع) نفس المرجع السابق المعابق 


\section{توثيق الإذن الطبي دراسة فقهية مقارنة}

$$
\text { رابعا: أن يكون الإذن بلفظ صريح أو شبهه: }
$$

فالإذن الصريح: كأن يقول المريض للطبيب أذنت لك بالفحص أو

$$
\text { إجراء الجراحة كذا. }
$$

والإذن غير الصريح: بأن يصرح المريض للطبيب تصريحا ضمنيا

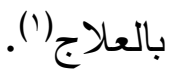

ويشترط أن يستمر الإذن حتى ينتهي الإجراء الطبي: فلو رجع

المريض في إذنه فإنه لا يسوغ إجباره وإكراهه بدعوى إذنه السابق (). 


\section{المبحث الخامس: \\ حمم توثيق الإذن الطبي

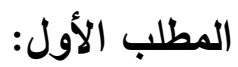 \\ مشروعية الإنن الطبي}

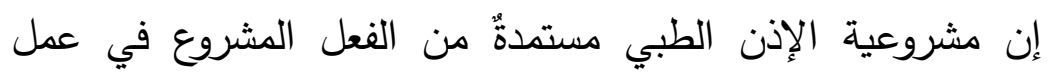
الطبيب؛ فإذا كان الإجراء الطبي مباحًا فإن الإذن مباحٌ، وإن كان الإجراء محرما فالإذن به محرم(') فيأخذ حكم التداوي، وقد اختلف الفقهاء في حكم التداوي إلى خمسة أقوال:

القول الأول: إباحة التداوي وذهب إليه جمهور الحنفية(r) والمالكية

$$
\text { في المذهب(r) وبعض الحنابلة(£). }
$$

القول الثاني: إباحة التداوي وتركه أفضل وذهب إليه بعض الثافعية(0)، ونص عليه الإمام أحمد ووافقه بعض الحنابلة(؟) والزيدية(').

(1) الإذن في إجراء العمليات الطبية أحكامه وآثاره لفضيلة القاضي هاني الجبير ص r. بحث منشور على مواقع التواصل.من دون طبعة.

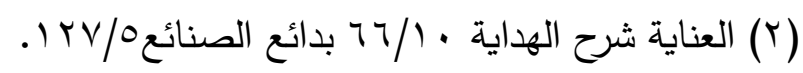

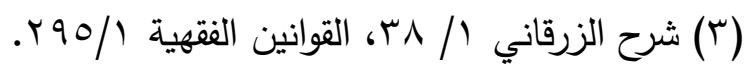

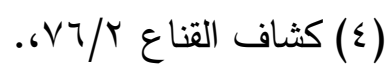

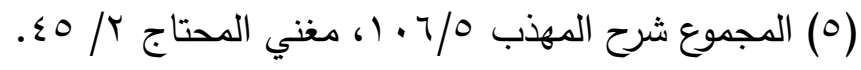

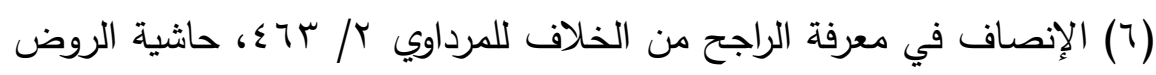

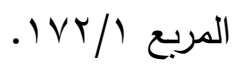

$$
\begin{aligned}
& \text { (V) نيل الأوطار ^/ اسبع. (V) }
\end{aligned}
$$




\section{توثيق الإذن الطبي دراسة فقهية مقارنة}

القول الثالث: يستحب التداوي ذهب إلى ذلك الثافعية(')، وبعض

أصحاب الإمام أحمد من الحنابلة (؟).

القول الرابع: يجب التداوي ذهب إلى ذلك الحنفية() وابن حزم(๕)..

القول الخامس: يكره التداوي وذهب إلى ذلك بعض العلماء(0)، بل

وذهب غلاة الصوفية إلى إنكاره(؟).

سبب الاختلاف: يرجع سبب اختلاف الفقهاء في حكم التداوي إلى

التعارض الظاهري بين النصوص الواردة في هذا الثأن وسيظهر ذلك من خلال عرض الأدلة.

الأدلة:

أدلة القول الأول: استدل أصحاب القول الأول على إباحة التداوي بما

يلي:

الاليل الأول: عن أسامة بن شريك، قال: قالت الأعراب: (يَا رَسُولَ

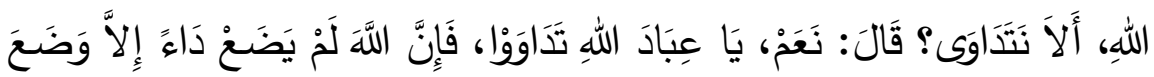

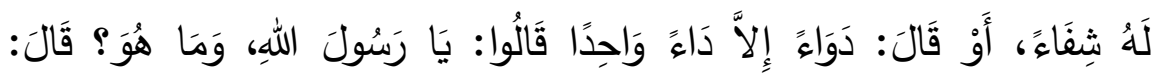

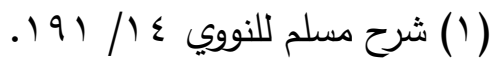

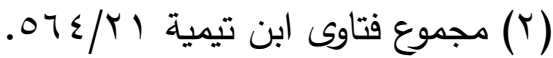

( ) ( البحر الرائق

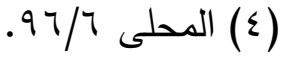

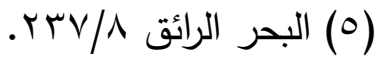

(7) شرح النووي على مسلم ع // 191. 


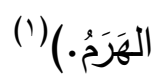

وجه الدلالة: في الحديث إثبات الطب والعلاج وأن التداوي مباح غير

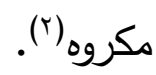

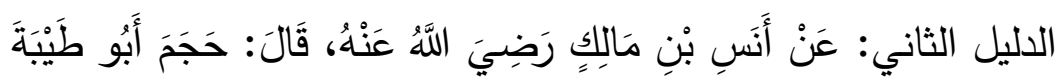

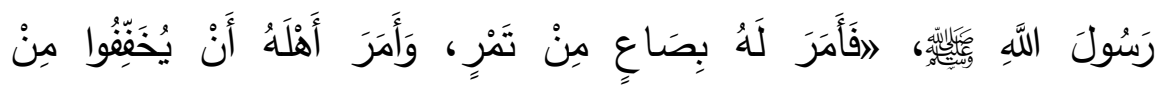

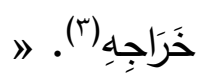

وجه الدلالة: يدل هذا الحديث على إباحة التداوي وقد قال ابن عبد

هذا حديث لا خلاف في صحته، وقد أفصح بأن أجرة الحجام تطيب

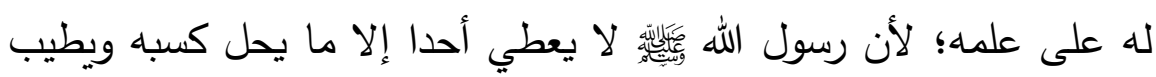
أكله سواء كان عوضا من علمه أو غير عوض، ولا يجوز في أخلاقه وسنته وشريعته أن يعطي عوضا على شيء من الباطل(ء).

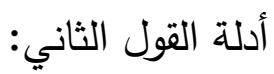

استدل أصحاب القول الثاني على أنه يباح التداوي بما استدل به

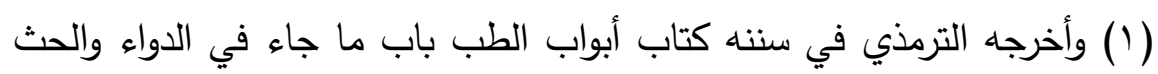

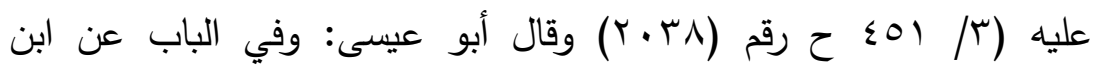
مسعود، وأبي هريرة، وهذا حديث حسن صحيح.

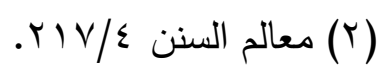
(r) أخرجه البخاري في صحيحه كتاب البيوع باب ذكر الحجام س/r (r/ ح رقم

$$
\begin{aligned}
& \text { (r) r.) } \\
& \text { (ع) الاستذكار (10/1). }
\end{aligned}
$$


أصحاب القول الأول من أدلة من السنة؛ وأما الاستدلال على أن تركه

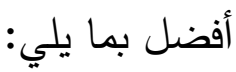

الدليل الأول: حَدَّنَيْي عَطَاءُ بْنُ أَبِي رَبَاحِ، قَالَ: قَالَ لِي ابْنُ عَبَّاسِ:

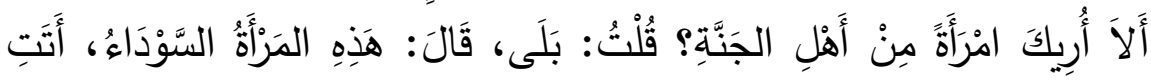

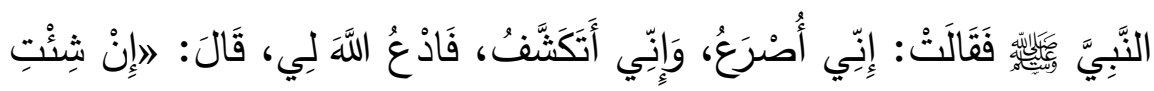

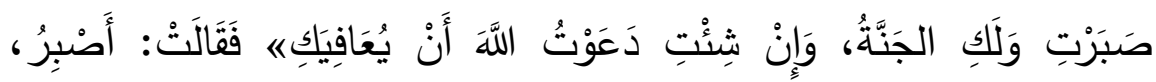

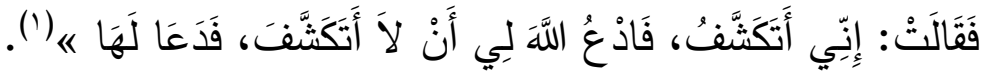
وجه الدلالة: يدل الحديث على أن الصبر على بلايا الدنيا يورث الجنة، وأن الأخذ بالثدة أفضل من الأخذ بالرخصة لمن وجد في نفسه الطاقة ولم يضعف عن التزام الثدة، وفيه دليل على جواز ترك التداوي، وفيه أن علاج الأمراض كلها بالاعاء والالتجاء إلى الله أنجْعُ وأنفع من العلاج بالعقاقير، وأن تأثير ذلك وانفعال البدن منه أعظم من تأثير الأدوية البدنية، ولكن إنما ينجع بأمرين أحدهما: من جهة العليل وهو صدق القصد والير والآخر من جهة المداوي: وهو قوة توجهه وقوة قلبه بالتقوى والتوكل والله

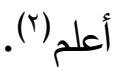

الاليل الثاني: عن سَعِيدِ بْنِ جُبَيْرِ، قَالَ: عَنْ ابْنِ عَبَّاسٍ: أَنَّ رَسُولَ اللَّهِ

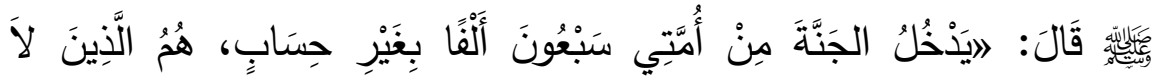

(1) أخرجه البخاري في صحيحه كتاب المرضى، باب فضل من يصرع من الريح

$$
\begin{aligned}
& \text { (11/ }
\end{aligned}
$$

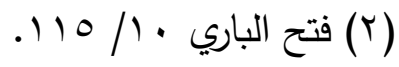




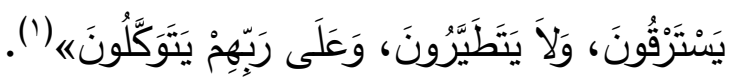
وجـه الدلالـة: يـدل هذا الحديث دلالــة واضـحة على مـدح مـن ترك التداوي متوكلا على الله، ...فلم يتسببوا فى دفع ما أوقعـه بهم، ولا شك فى ولى فضيلة هذه الحالة ورجحان صاحبها.

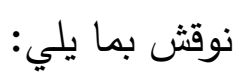
أولاً: أن المراد بالحديث الذين يجتنبون فعل ذلك في الصحة خشية

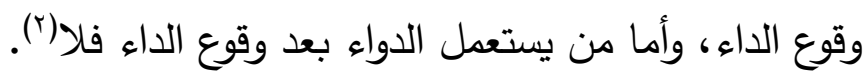
ورد ذلك: بأنـه قد ثبت في الأحاديث الصـيحة استعمال ذلك قبل

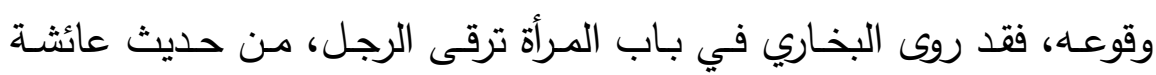

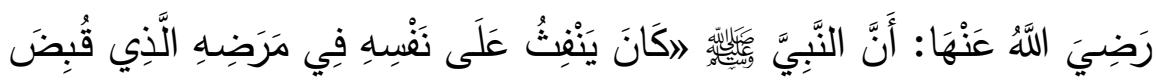

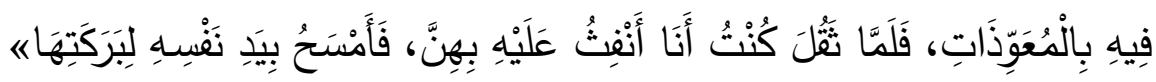

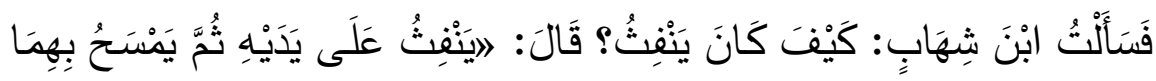

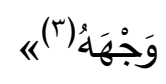

الثاني: أن هذا الحديث ليس فيه مدح لمن ترك التداوي وقد قال ابن

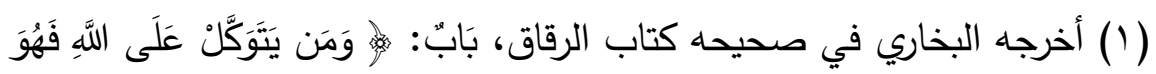

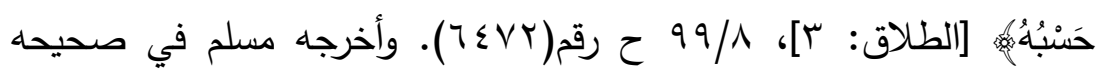

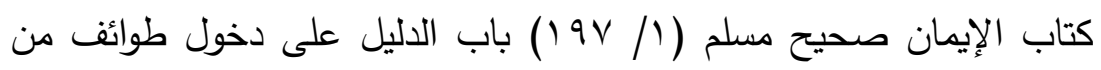

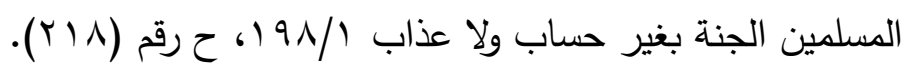

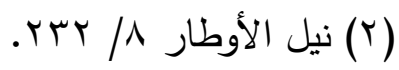

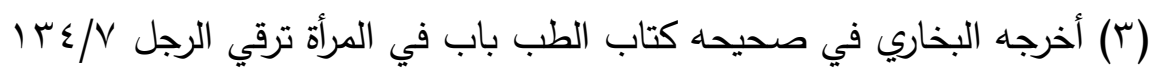

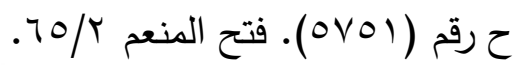




\section{توثيق الإذن الطبي دراسة فقهية مقارنة}

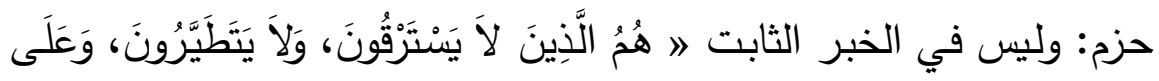

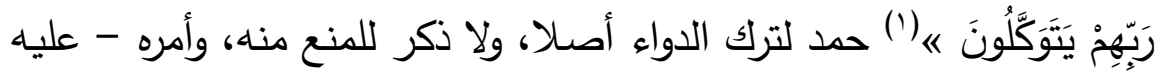

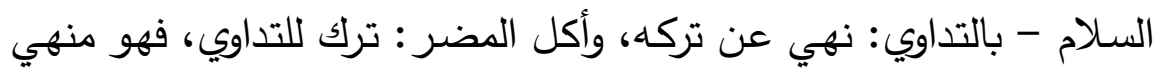

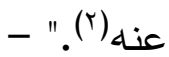

ثالثاً: الأمر بالتوكل محمول على التوكل عند اكتساب الأسباب، ثم

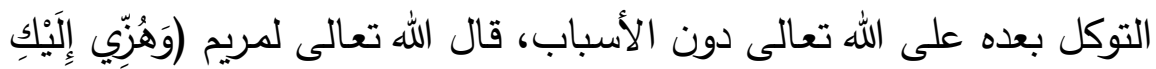

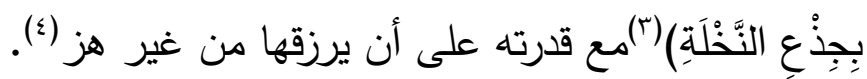

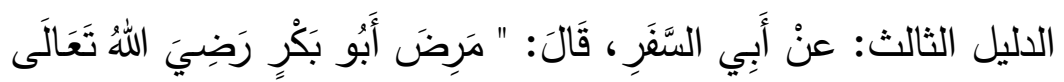

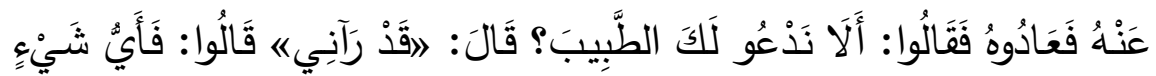

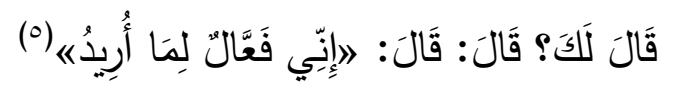
وجه الدلالة: تدل هذه الآثار دلالة واضحة على ترك التداوي وأنه لا

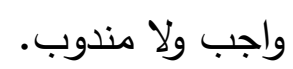

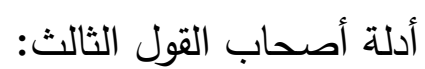
استدل أصحاب القول الثالث على استحباب التداوي بما يلي:

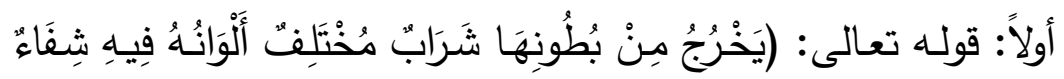

$$
\begin{aligned}
& \text { (1) سبق تخريجه ص آ" } \\
& \text { (r) المحلى بالأثار } 97 / 7 \text { (T) }
\end{aligned}
$$

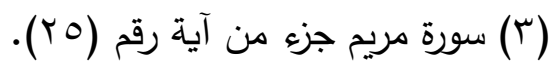

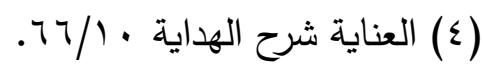

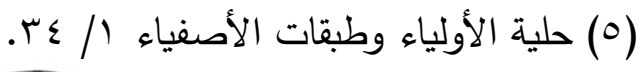


(ل) لِنَّاسِ) (1)

قال القصاب: هو دليل على إباحة التداوي مع ما جاء عن رسول الله،

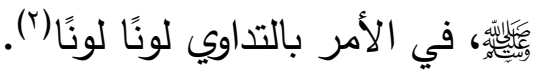

ثانيا: جملة من أحاديث رسول الله

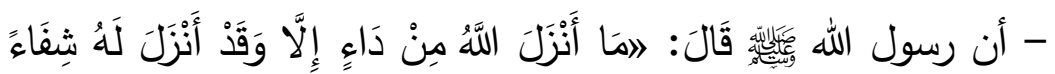

وَفِي أَلْبَانِ الَْبَََرِ شِفَاءُ مِنْ كُلِّ دَاعِه(َ)

وجه الدلالة: فى هذا الحديث إثارة إلى استحباب الدواء.... وهذه الأحاديث

جمل من علوم الدين والدنيا، وصحة علم الطب وجواز التطبيب في الجملة

واستحبابه بالأمور المذكورة(ء).

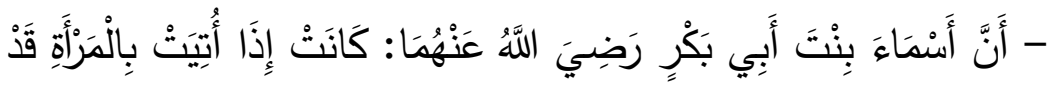

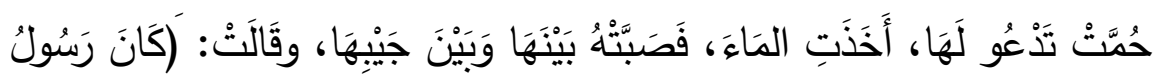

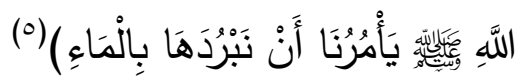

(1) سورة النحل جزء من آية رقم(9 7).

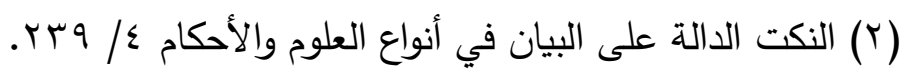

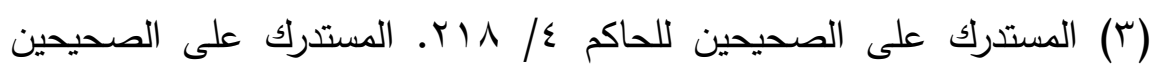

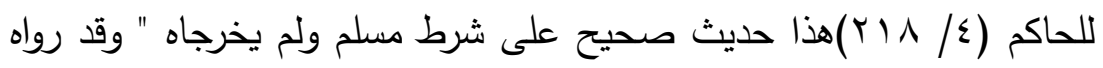
أبو عبد الرحمن السلمي، وطارق بن شهاب، عن عبد الله بن مسعود [التعليق

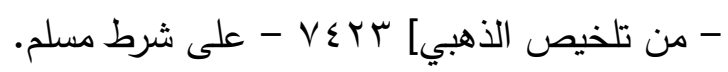

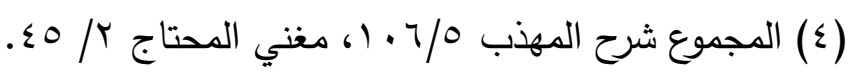

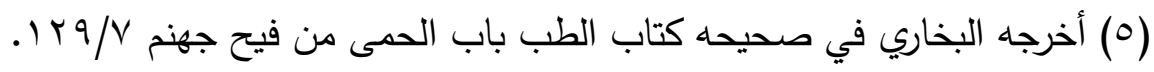

$$
\text { ح رقم (OVY). }
$$




\section{توثيق الإذن الطبي دراسة فقهية مقارنة}

وجه الدلالة: يدل هذا الحديث دلالة واضحة على استحباب

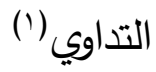

نوقش الاستدلال بهذه الأحاديث من عدة أوجه:

أولا: ليس كل المرضى يبرؤون بتعاطي الدواء وهذا مشاهد ملموس.

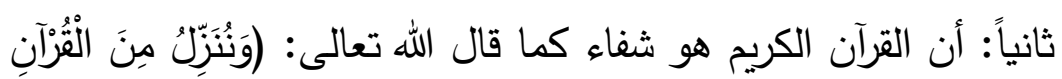

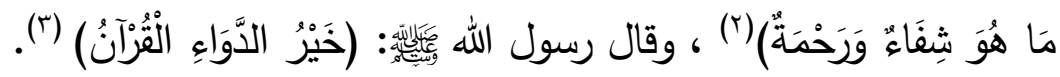

$$
\text { أجيب عن ذلك بما يلي: }
$$

الأول: أنه اختلف العلماء في (من) هل هي للتبعيض أم للجنس. وقد

قال ابن القيم: 》انه ها هنا لبيان الجنس لا للتبعيض هذا أصح القولين. الثاني: أن الحديث ضعيف فقد جاء في مصباح الزجاجة(؛). " هذا إسناد فيه الحارث بن عبد الله الأعور وهو ضعيف وله شاهد من حديث ابن مسعود رواه الحاكم مرفوعا وموقوفا".

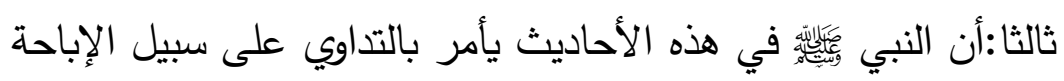
وليس الاستحباب.

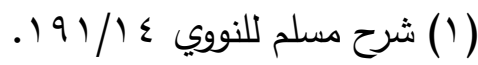

$$
\begin{aligned}
& \text { (Y) سورة الإسراء جزء من آية (Y) (Y). }
\end{aligned}
$$

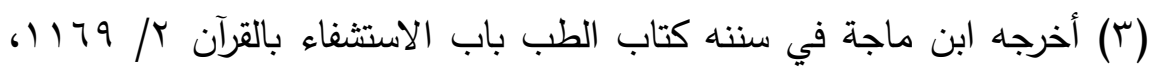

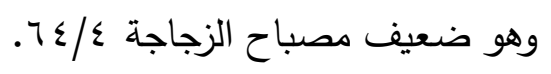




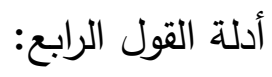

استدل أصحاب القول الرابع على وجوب التداوي بما يلي:

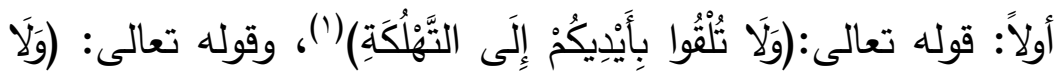

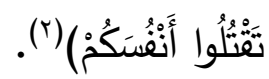

وجه الدلالة: تدل الآية دلالة واضحة على وجوب التداوي؛ لأن في

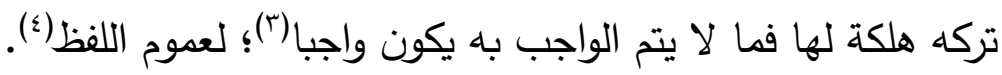

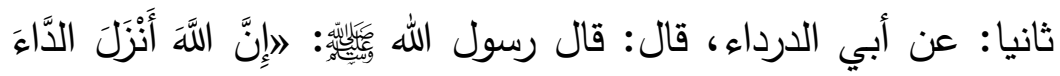

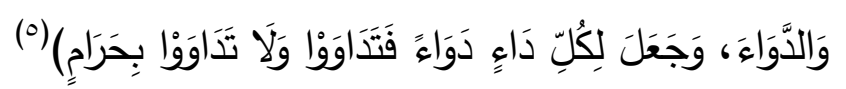

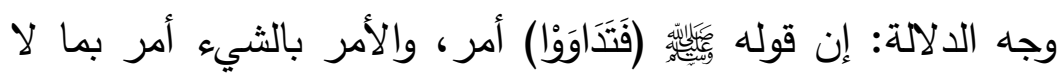
يتم الواجب إلا به(؟)، فهو واجب.

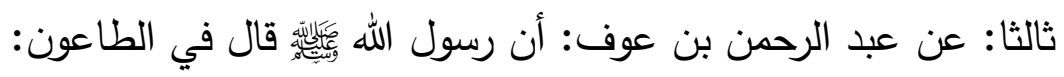

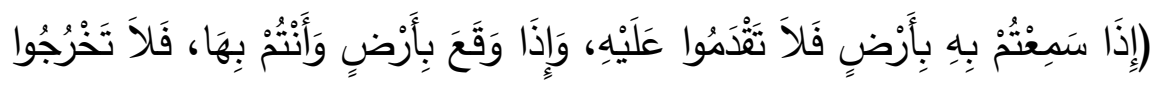

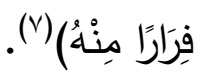

(1) سورة البقرة جزء من آية رقم (190 (1).

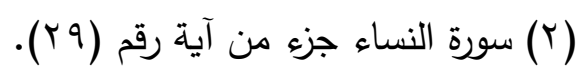

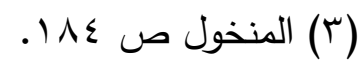

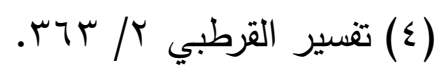
(0) أخرجه أبو داود في سننه كتاب الطب باب في الأدوية المكروهة ح رقم (r^v乏)، وضعغه الألباني.

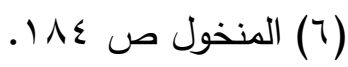
أخرجه البخاري في صحيحه كتاب الطب باب ما يذكر في الطاعون V) (V)

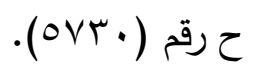


وجه الدلالة: ينبغي على المسلم أن يتخذ الأسباب الموجبة لنجاته

$$
\text { والتداوي والإذن به منها ('). }
$$

نوقش ذلك: بأن هذا الحديث خاص بالطاعون ولم يأمر باتخاذ الأسباب التي قد تفضي إلى المرض، وحديثنا عمن وقع في المرض فلا يشمله الحديث، بل وأبلغ من ذلك أن آخر الحديث ينهى عن الفرار من إنى الطاعون، ولو صح استدلالهم لأمرهم بالخروج من هذه الأرض ولم يأمرهم

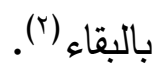

رابعا: قياس وجوب التداوي على وجوب أكل الميتة للمضطر وإساغة اللقمة (ז) بالخمر لبقاء النفس وصيانة لها عن الهلاك. نوقش ذلك: بأنه قياس مع الفارق لأن أكل الميتة للمضطر وإساغة اللقمة لا نقطع بإفادته بخلاف غيره فهو عند الضرورة(؛).

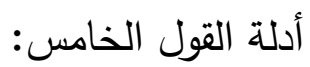
استدل أصحاب القول الخامس على كراهية التداوي؛ بما يلي: الاليل الأول: ما سبق أن استدل به أصحاب القول الثاني وهو

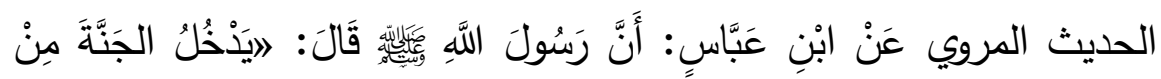

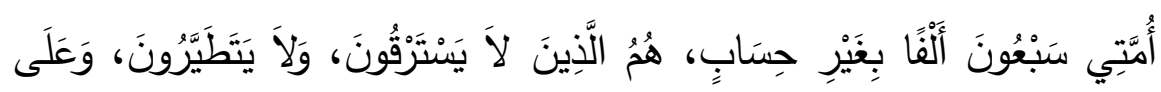

$$
\begin{aligned}
& \text { (1) الإذن في الحالات المستعجلة والحرجة ص • (1. }
\end{aligned}
$$

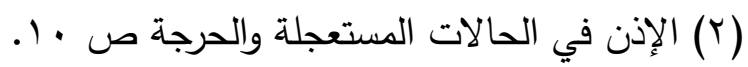

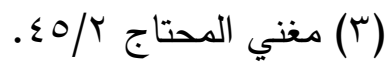

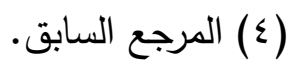




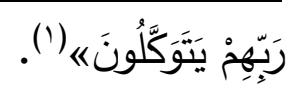

وجه الدلالة: يدل هذا الحديث على الحث على ترك التداوي فيكون

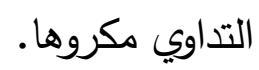

الدليل الثاني: كل شيء بقضاء وقدر فلاحاجة إلى التداوي(؟).

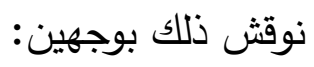

الأول: أن الله تعالى هو الفاعل، وأن التداوي هو أيضا من قدر الله، وهذا كالأمر بالدعاء، وكالأمر بقتال الكفار، وبالتحصن وتجنب الإلقاء باليد إلى التهلكة مع أن الأجل لايتغير والمقادير لاتتأخر ولا تتقدم عن أوقاتها ولابد من وقوع المقدرات(r).

الثاني: هذه الأدوية والرقى والتقى هي من قدر الله، فما خرج شيء عن قدره، بل يرد قدره بقدره، وهذا الرد من قدره، فلا سبيل إلى الخروج عن قدره بوجه ما، وهذا كرد قدر الجوع، والعطش والحر، والبرد بأضدادها، وكرد

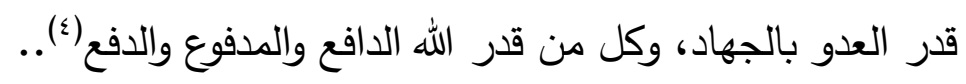

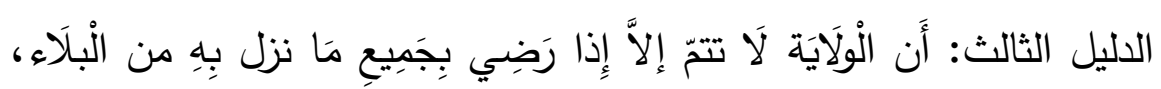

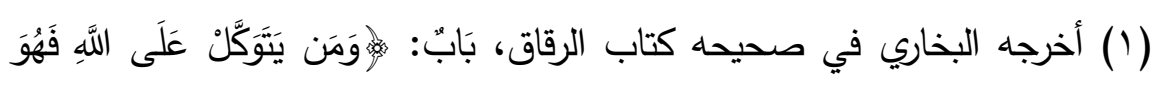

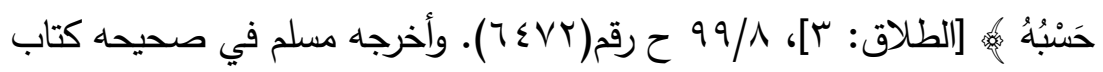

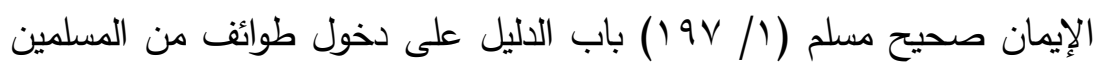

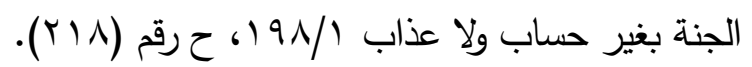

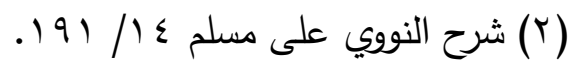

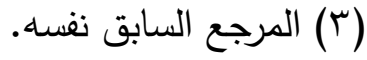

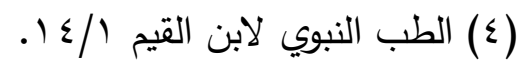




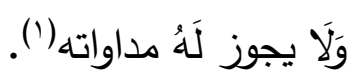

الرأي المختار : بعد عرض آراء الفقهاء وأدلتهم والمناقثة فإن القول المختار هو الجمع بين الأقوال فيما صدر عن فتوى مجمع الفقه الإسلامي؛ بأن التداوي يختلف حكمه باختلاف الأحوال والأشخاص(؟). فإنه تعتريه الأحكام الخمسة، بحسب الضرر المترتب على تركه، ونسبة نجاحه، ففي الحالات التي يكون أثر الدواء أخذه كعدمه فهذا يبقى على الجواز ، لكن إذا لإل ترجح أن نفعه محقق فهو على الاستحباب، وإذا ظهر أن ضره أكبر من

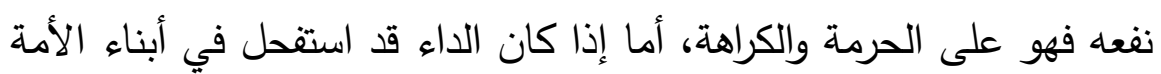

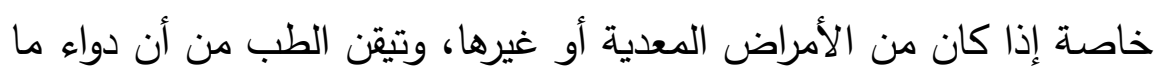

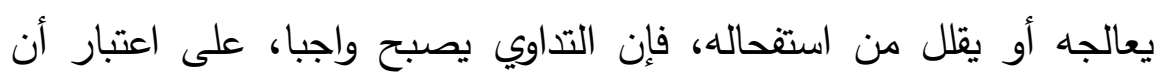
التداوي أو التطبيب إنما جعل لتخفيف الألم ودفع الضرر، ورفع الحرج عن المرضى وتحقيق المصالح لهم(ץ). وعليه فإن الإذن يأخذ نفس الحكم.

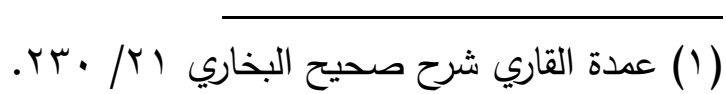

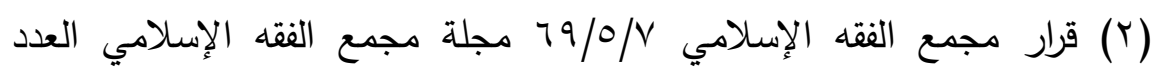

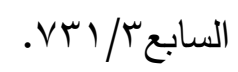

(r) الموازنة بين المصالح والمفاسد في التداوي بنقل الأعضاء البشرية عبد الغني يحياوي ص: الV، منشورات مؤسسة الفرقان للتراث الإسلامي، الطبعة الأولى:

$$
\text { . }
$$




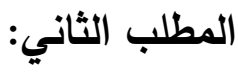 \\ حكم توثيق الإذن الطبي}

إن الله سبحانه وتعالى أرشد عباده المؤمنين إلى التوثيق ، وكما سبق فالإذن الطبي معاملة بين الطبيب والمريض لأنه يتعلق به حقوق وضمانات لذا سيكون الحديث في حكم توثيق الإذن الطبي في طرق توثيق المعاملات، والذي يظهر لي من كلام الفقهاء رحمه الله أن طرق التوثيق الثابتة هي الكتابة والثهادة، والتي تطورت الآن فصارت الكتابة الإكترونية، والتوثيق الإكتروني بالصورة والتسجيل، وعرضه مسجلا أو مباشرا لذا سأعرض آراء الفقهاء رحمه الله في التوثيق بالكتابة والثهادة في المعاملات.

وقد اختلف الفقهاء في حكم التوثيق بالكتابة والإشهاد على ثلاثة

القول الأول: أن التوثيق بالكتابة والإشهاد إنما هو للندب

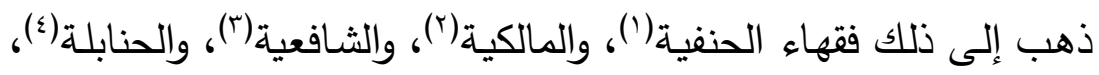

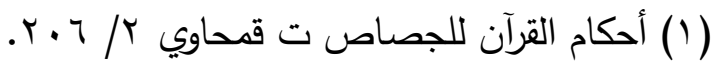

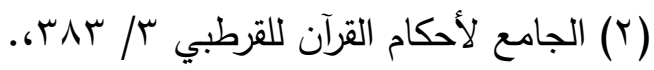

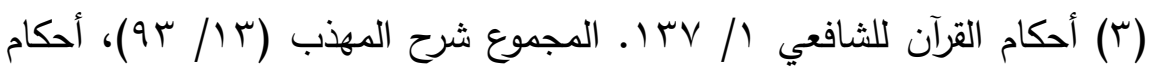
القرآن للكيا الهراسي / / • ب ب، تفسير البيضاوي = أنوار التنزيل وأسرار

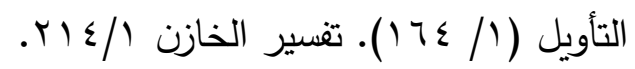

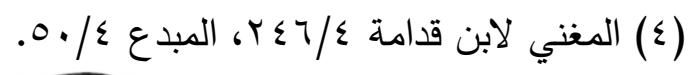




\section{توثيق الإذن الطبي دراسة فقهية مقارنة}

وذهب إليه أيضـا، أبو أيوب الأنصـاري(')، وغيره(r) من جمهور الأمـة من

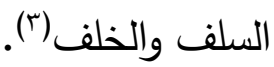

القول الثاني: أن الأمر بالكتابة والإشهاد حق واجب وفرض لازم. قال

بذلك الضحاك، وعطاء، وجابر بن زيد، والنخعي، وابن جرير الطبري(اء)

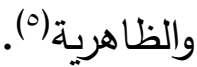

القول الثالث: أن الأمر بالكتابة كان واجبا فنسخ فصار مباحا وهو

قول أبي سعيد الخدري والحسن والثعبي (־).

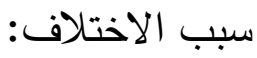

يرجع سبب اختلاف الفقهاء في حكم التوثيق بالكتابة والإشهاد إلى أن الإشهاد في آية المداينة منسوخ أم لا؟ فمن قال بنسخه قال بالوجوب. ومن

(1) أبو أيوب الأنصاري: هو خالد بن زيد بن كليب بن ثعلبة، أَبو أَيْوبَ الأنَصاري،

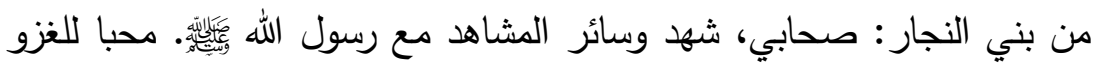
والجهاد. فلما توفي دفن في أصل حصن القسطنطينية. له 100 حديثا (جلاء

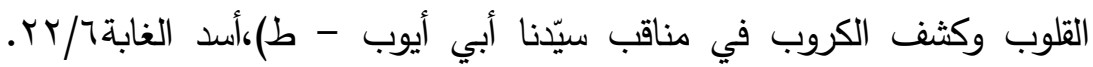

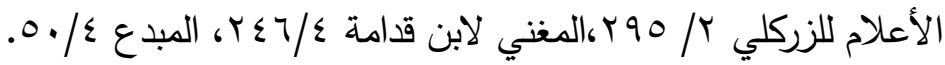

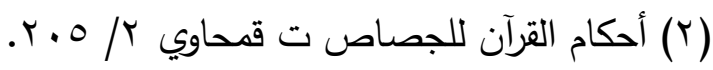

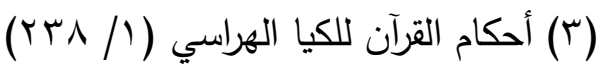

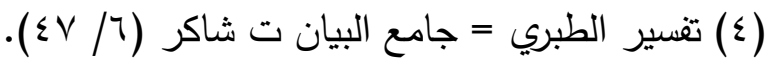

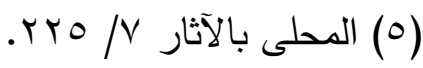
(T) الإيضاح لناسخ القرآن ومنسوخه لمعرفة أصوله واختلاف الناس فيه لأبي محمد القيسي تحقيق د/ أحمد حسن فرحات دار المنارة جدة ط.

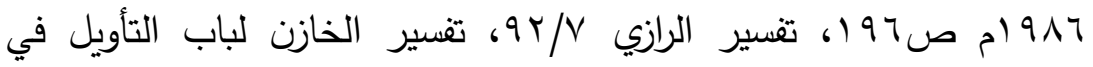

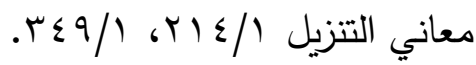


وقال القيسي: (هذا مذهب من رأى أن الآية محكمة وهي عند آخرين

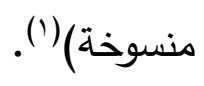

الأدلة:

أدلة القول الأول: استدل أصحاب القول الأول على أن التوثيق والأمر بالكتابة والإشهاد في المعاملات للندب بما يلي:

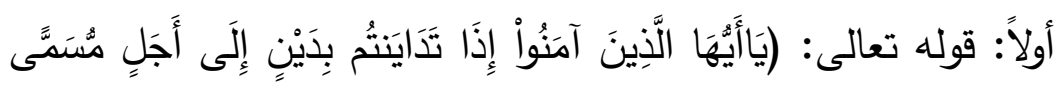

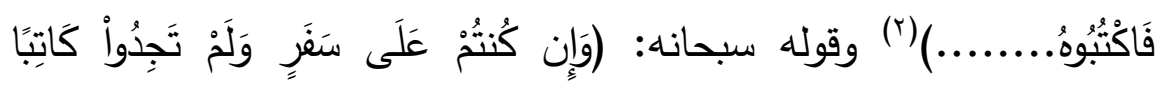

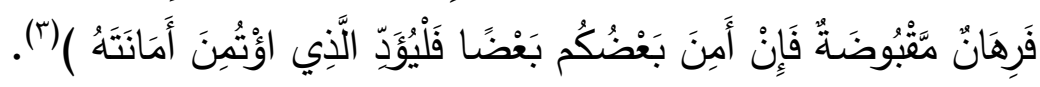

وجه الدلالة: تدل الآية الكريمة على أن الأمر بكتابة الدين واجبة،

ولكن وجدت قرينة صارفة لهذا الحكم من الوجوب إلى الندب وهي قوله

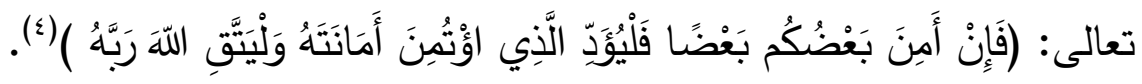

وبين ابن قدامة - رحمه الله- أن أقل أحوال الأمر الاستحباب. ولأنه

أقطع للنزاع، وأبعد من التجاحد، فكان أولى، ويختص ذلك بما له خطر، فأما

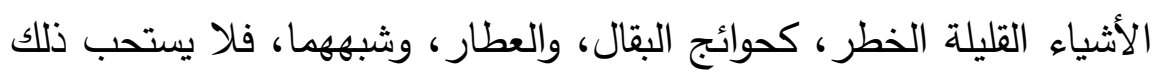
فيها؛ لأن العقود فيها تكثر، فيثق الإشهاد عليها، وتقبح إقامة البينة عليها، والترافع إلى الحاكم من أجلها، بخلاف الكثير · وليس الإشهاد بواجب في

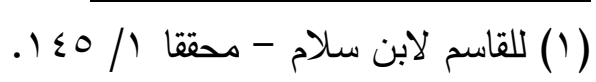

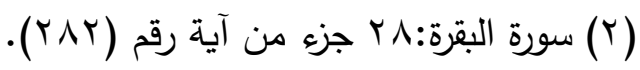

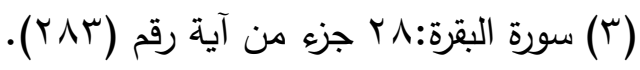

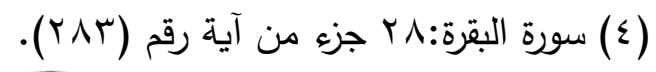




\section{توثيق الإذن الطبي دراسة فقهية مقارنة}

واحد منهما، ولا شرطا له (1).

نوقش ذلك بما يلي: بأنه قد تتابعت الأوامر في الآية وتأكدت حتى في حال السفه والضعف والعجز ، فقد أمر ولي من عليه الحق من هؤلاء بأن

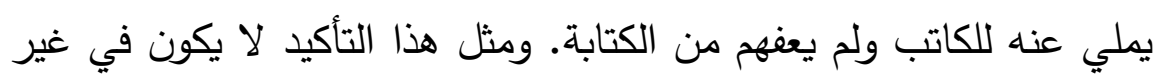

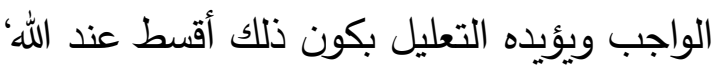

وأن الآية في الأمانة على الإطلاق، فإذا دخل في عمومها ما ذكر

من الائتمان على الثمن عند فقد الكاتب فلا يجعل دليلا على ترك الواجب -

$$
\text { وهو الكتابة - في كل حال(r). }
$$

أجيب عن ذلك: بأنه هناك من القرائن ما حملت الأمر من الوجوب

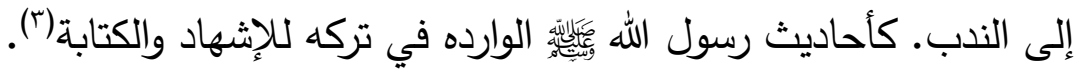

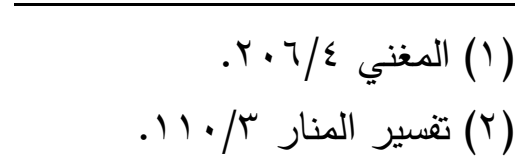

(r) ويمكن الرجوع إلى الحديث المطول " حديث الظعينة" الذي أخرجه ابن حبان في صحيحه صحيح ابن حبان - مخرجا ـ (، كتاب التاريخ باب كتب النبي

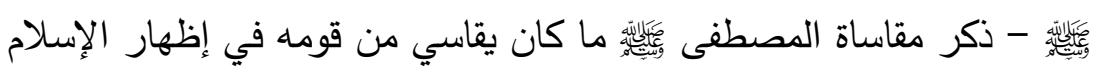

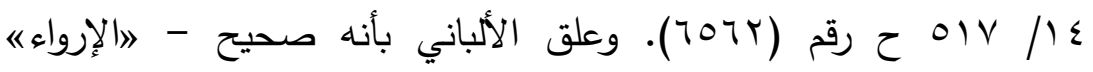

( 
الدليل الثاني: الأحاديث الواردة عن رسول الله

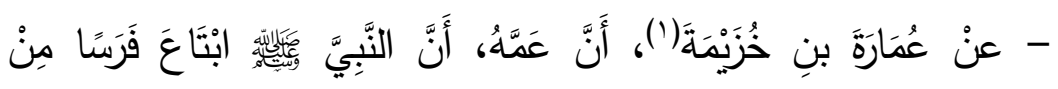

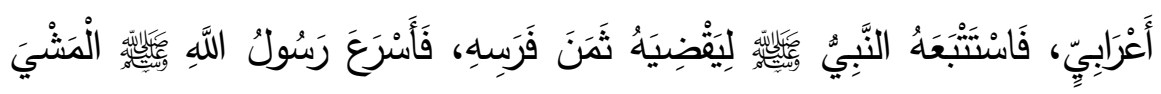

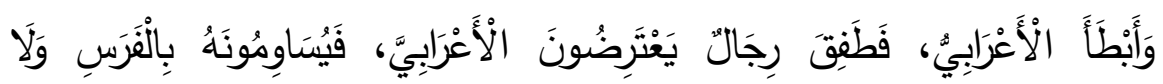

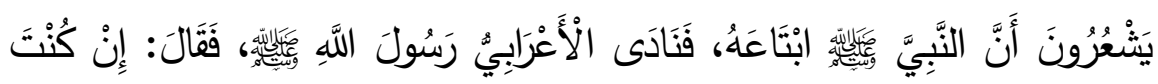

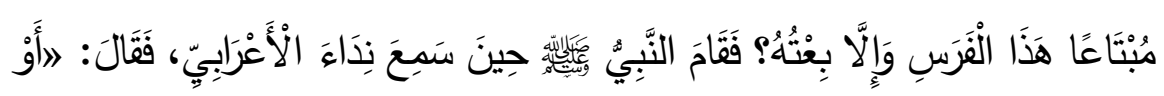

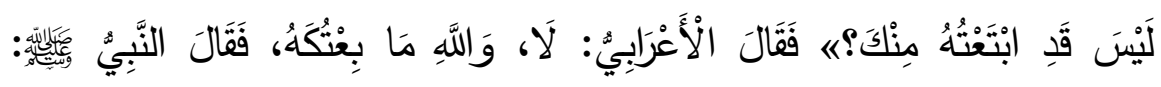

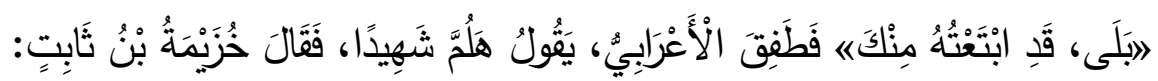

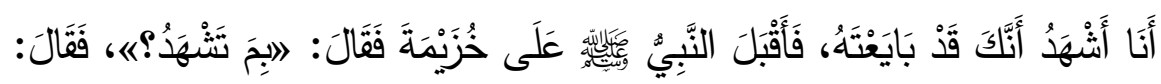

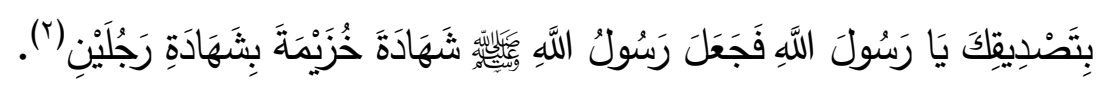
وجه الدلالة: يدل الحديث صراحة على ترك الإشهاد في البيع ولو

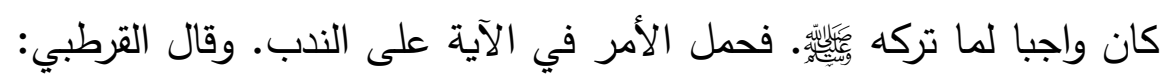

(1) عمارة بن خزيمة: بن ثابت الأنصاري الأوسي أبو عبد الله ويقال أبو محمد

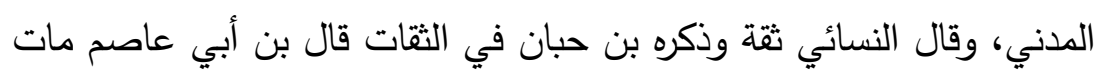

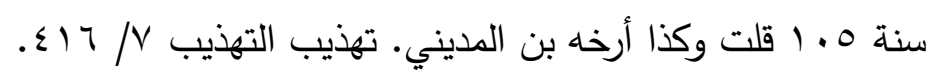
(Y) أخرجه أبو داود في سننه كتاب الأقضية باب إذا علم الحاكم صدق الثاهد

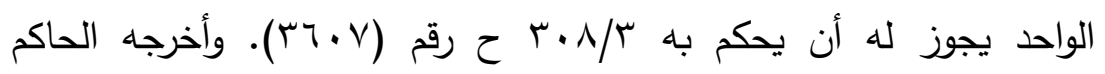

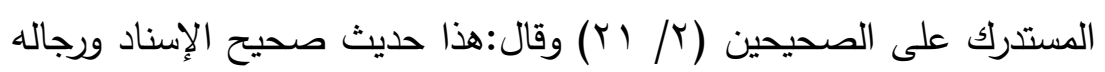
باتفاق الثيخين ثقات ولم يخرجاه اوعمارة بن خزيمة سمع هذا الحديث من الإسنا

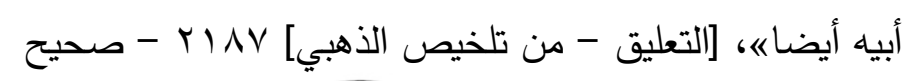




\section{توثيق الإذن الطبي دراسة فقهية مقارنة}

ما جاء من صريح السنة في ترك الإشهاد('). ناقش أصحاب القول الثاني هذا الحديث من وجوه: أولها: أنه خبر لا يصح لأنه راجع إلى عمارة بن خزيمة - وهو

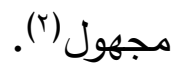

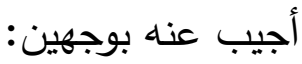

الأول: بما قاله الحاكم في المستدرك: هذا حديث صحيح الإسناد ورجاله باتفاق الثيخين ثقات ولم يخرجاه اوعمارة بن خزيمة سمع هذا

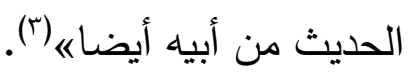
الثاني: جاء في تهذيب التهذيب: " قال ابن سعد: وكان ثقة قليل الحديث وغفل بن حزم في المحلي قال إنه مجهول لا يدري من هو (๕).

والثاني: أنه لو صح لما كانت لهم فيه حجة؛ لأنه ليس فيه: أن الأمر تأخر مقدار مدة يمكن فيها الإثهاد، فلم يثهد - عليه السلام -، وإنما فيه:

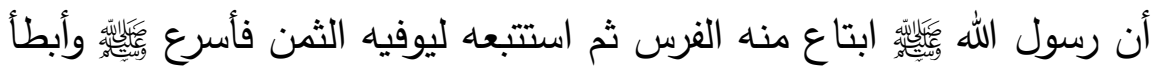

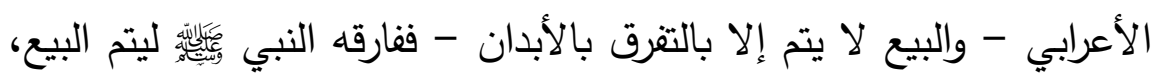
وإلا فلم يكن تم بعد، وإنما يجب الإشهاد بعد تمام البيع وصحته، لا قبل أن

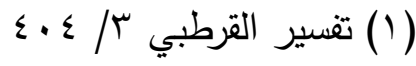

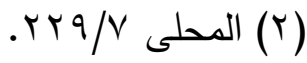

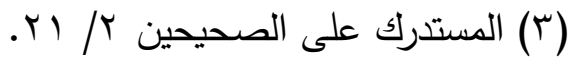

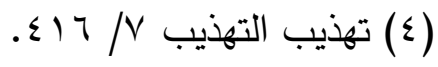




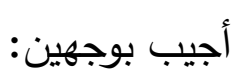

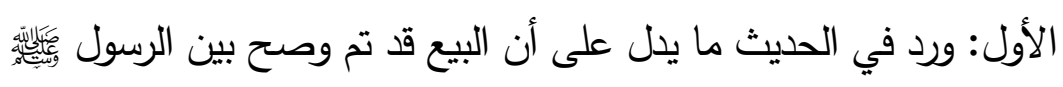

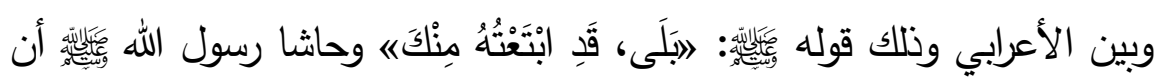
يدعي شينًا لم يتم بعد (广).

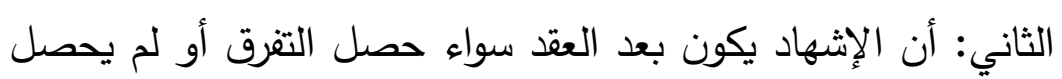

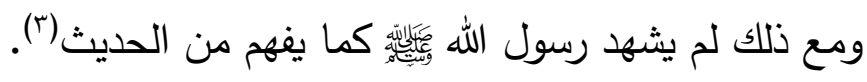
الثالث: أنه حتى لو صح لهم الخبر - وهو لا يصح - ثم صح فيه:

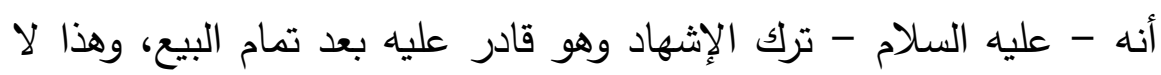

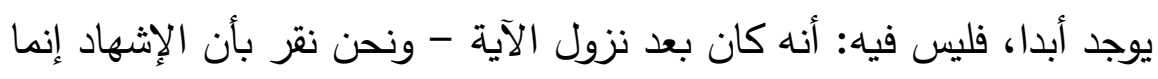

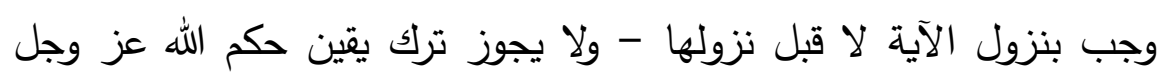
بظن كاذب لا يحل القطع به - فبطل تعلقه بهذا الخبر جملة (5). أجيب على ذلك بوجهين:

الأول: بأنه يمكن ألا نوافق على أن معرفة التاريخ شرط لصحة القول

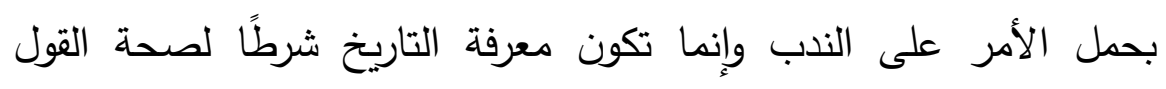

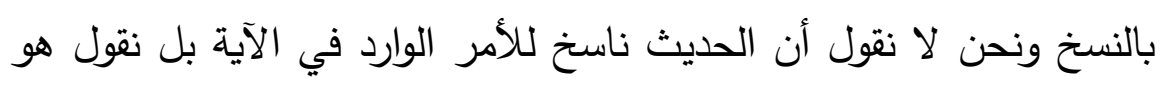

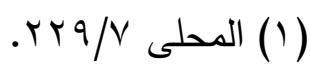

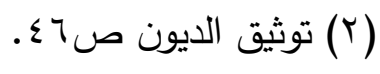

$$
\begin{aligned}
& \text { (Y) المرجع السابق. }
\end{aligned}
$$

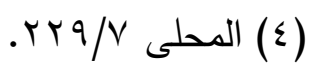


صارف له إلى الندب فقط (').

الثاني: عن الثَعبي: (أَنَّ الْمِقْدَادَ اسْتَنْلَفَ مِنْ عُشْمَانَ سَبْعَةَ آلَأَفِ

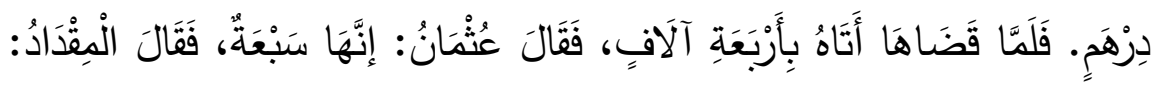

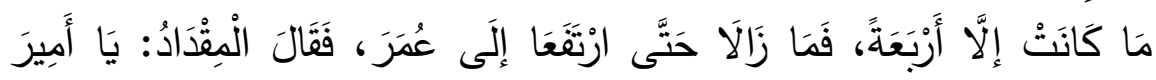

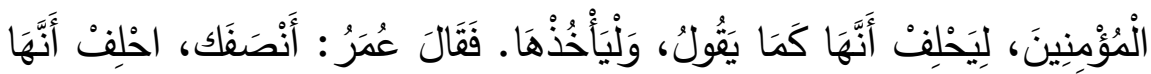

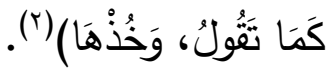
.وهذا يدل على أن المقداد وعثمان لم يوثقا الدين بالكتابة فدل على

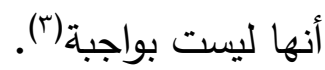

الرابع: قولكم: إن الحديث ليس فيه ذكر للإشهاد، وهذا دليل على ترك

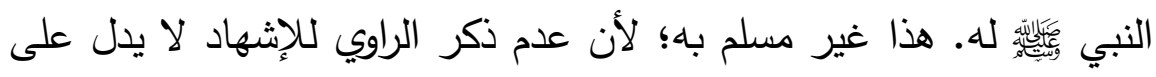

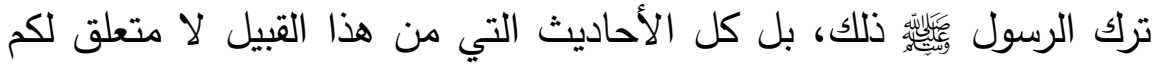
فيها، لأنها جميعا لم تتعرض لإثبات الإشهاد أو نفيه(؛).

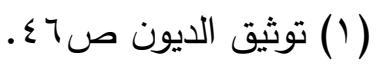

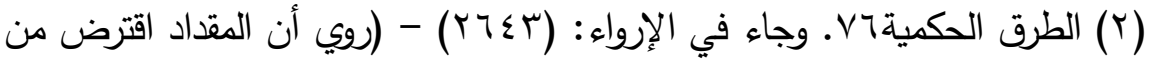

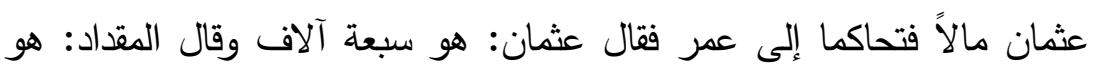
أربعة آلاف، فقال المقداد لعثمان: احلف أنه سبعة آلاف، فقال عمر : أنصفك. احلف أنها كما تقول وخذها" رواه أبو عبيد)* ضعيف، أخرجه البيهقي

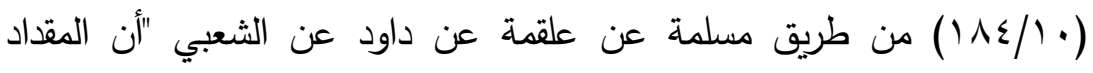
استقرض من عثمان... "، وقال: "هذا إسناد صحيح إلا أنه منقطع"، يعني أن أن

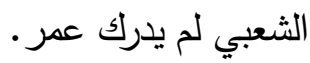

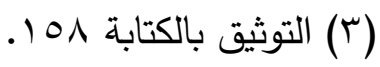

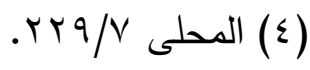


وقد أجاب عليه صاحب توثيق الدين بجوابين:

الأول: إن هذه الأحاديث لم يصرح الرواة فيها بأنه أثهد على بيعه،

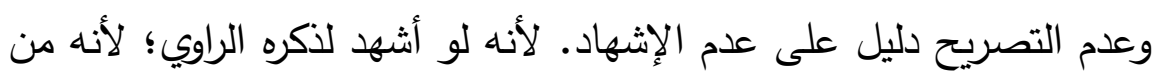
جملة الحديث المروي، فلما لم يذكره دل على عدم حصوله. الثاني: سلمنا جدلا بما قلتم: من أن هذه الأحاديث ليس فيها تصريح

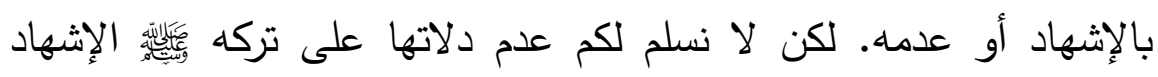

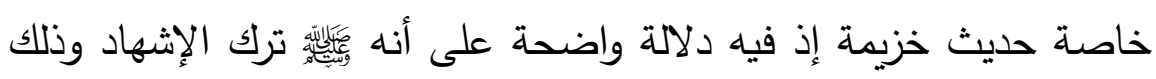
في مساق الحديث بينه وبين الأعرابي حيث ناداه الأعرابي قائلا إن كنت

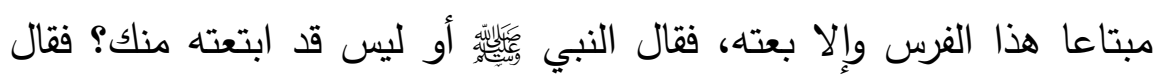

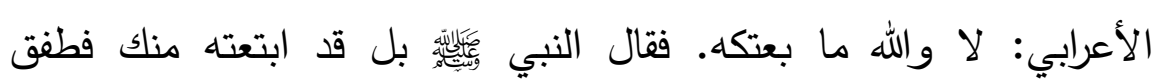

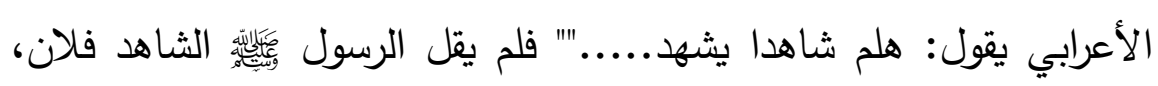

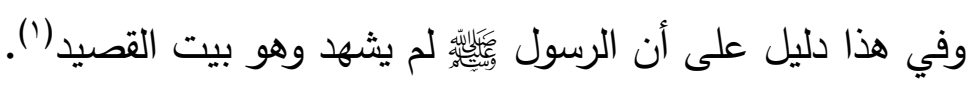
الدليل الثالث: كان الصحابة يتبايعون في عصره في الأسواق، فلم

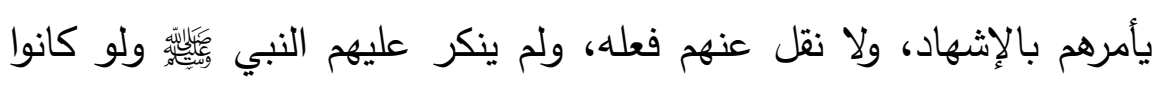
يشهدون في كل بيعاتهم لما أخل بنقله(ז). كما أننا نرى جمهور المسلمين في جميع ديار الإسلام يبيعون بالأثمان المؤجلة من غير كتابة ولا إشهاد، وذلك

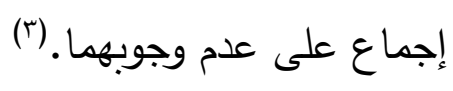

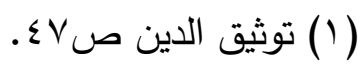

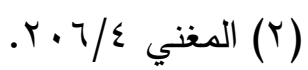

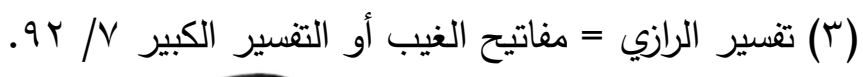




\section{توثيق الإذن الطبي دراسة فقهية مقارنة}

قال آخرون: هذا الأمر محمول على الندب، وعلى هذا جمهور

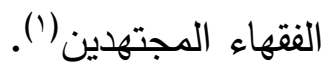

نوقش ذلك: وأما دعوى تعامل أهل الصدر الأول وغيرهم من

المسلمين بغير كتابة ولا إثهاد فهي على إطلاقها باطلة. فإنه لم يؤثر عن الصحابة الذين يحتج بمعاملاتهم، ولا عن التابعين شيء صحيح يؤيد هذه الدعوى، وإنما اغتر هؤلاء القائلون من الفقهاء بعدم وجوب الكتابة والإشهاد بمعاملات أهل عصرهم، فجعلوا ذلك عاما ولم يرووا عن الصحابة فيه شيئا

صحيحا واقعا بالفعل(ז) (ب).

الدليل الرابع: إن في إيجاب الكتابة والإشهاد أعظم التشديد على

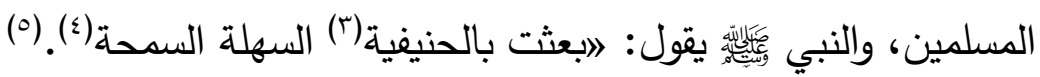

$$
\begin{aligned}
& \text { (1) نفسير الرازي }
\end{aligned}
$$

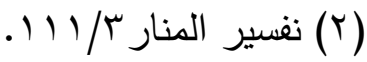

(r) الحنيفية: المائل إلى الإسلام الثابت عليه. النهاية في غريب الحديث والأثر

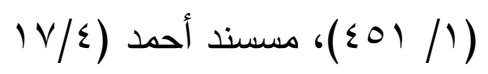

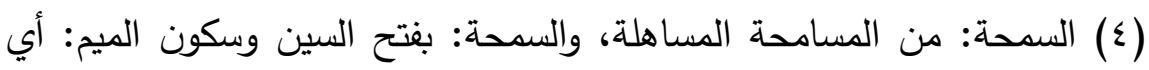

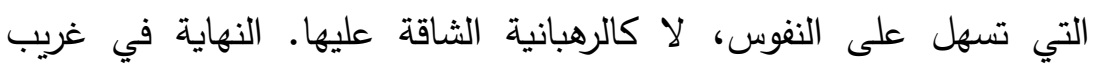

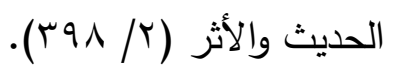

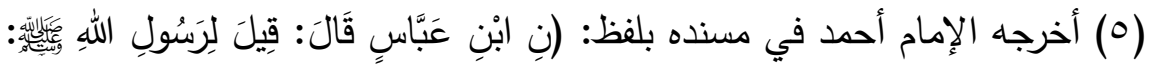

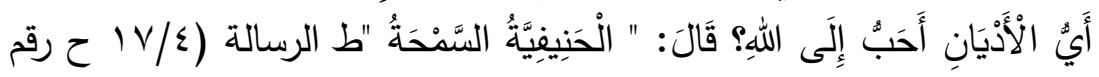

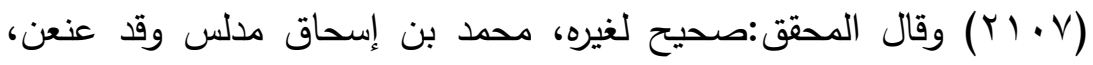
وداود بن الحصين ثقة مشهور لكن له غرائب تُستنكر • وذكره البخاري تعليقا

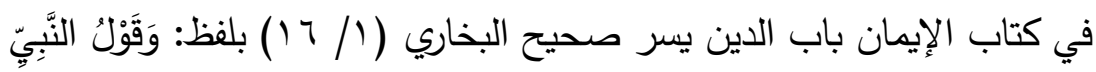

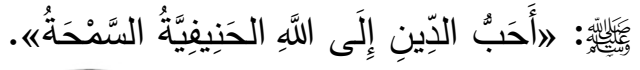


ولأن المبايعة تكثر بين الناس في أسواقهم وغيرها، فلو وجب الإشهاد في كل ما يتبايعونه، أفضى إلى الحرج المحطوط عنا بقوله تعالى: (وَجَاهِدُوا

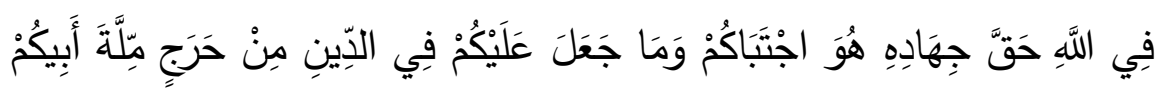

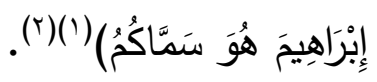
أدلة أصحاب القول الثاني: استدلوا على وجوب التوثيق بالكتابة بما يلي:

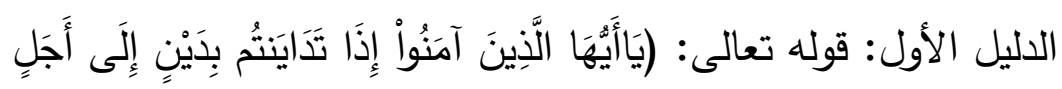

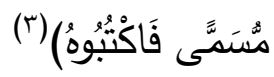

وجه الدلالة: أن الله عز وجل أمر المتداينين إلى أجل مسمى باكتتاب كتب الدين بينهم، وأمر الكاتب أن يكتب ذلك بينهم بالعدل، وأمر الله فرض باله لازم، إلا أن تقوم حجة بأنه إرشاد وندب. ولا دلالة تدل على أن أمره جل

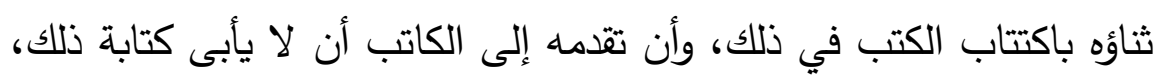
ندب وإرشاد، فذلك فرض عليهح لا يسعهم تضييعه، ومن ضيعه منهم كان حرجا بتضييعه (๕).

وعن ابن عباس - رضي الله عنه- أنه قال لما قيل له إن آية الدين

منسوخة فقال: (لا والله بل آية الدين محكمة ما فيها نسخ)(ْ).

$$
\begin{aligned}
& \text { (1) سورة الحج جزء من آية V^. } \\
& \text { ( T) }
\end{aligned}
$$

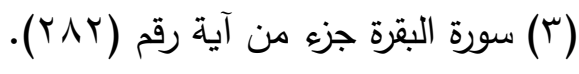

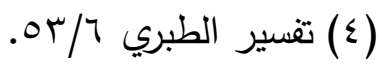

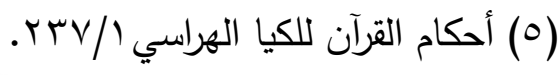




\section{توثيق الإذن الطبي دراسة فقهية مقارنة}

نوقش ذلك: سلمنا الأمر أنه للوجوب، ولكن وجدت القرينة التي تصرف الأمر من الوجوب إلى الندب منها الأحاديث التي جاء فيها ترك

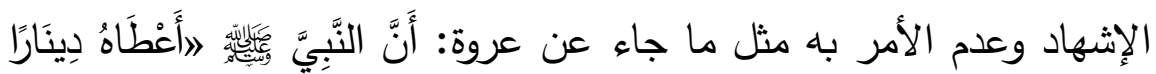

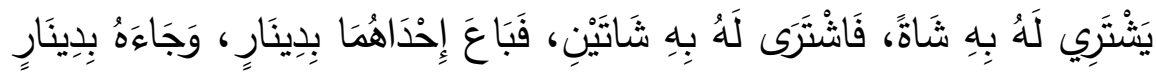

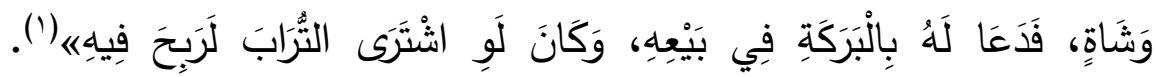

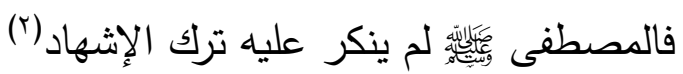

ثانيا: أن الأمر في الآية كان واجبا ونسخ بقوله تعالى: (فَإنْ أَمِنَ

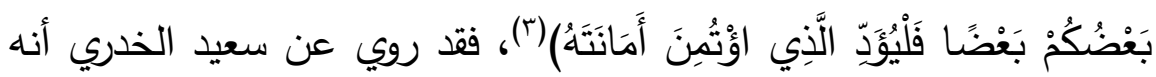
قرأ هذه الآية فقال: نسخ لكل ما تقدم يعني من الأمر بالكتاب والإشهاد

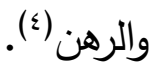

ونوقش ما روي عن ابن عباس - رضي الله عنه- من أن آية الدين

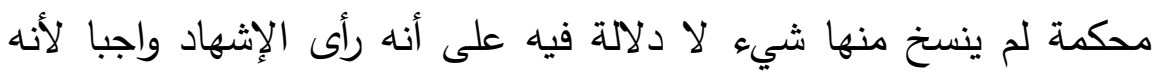
جائز أن يريد أن الجميع ورد معا فكان في نسق التلاوة ما أوجب أن يكون

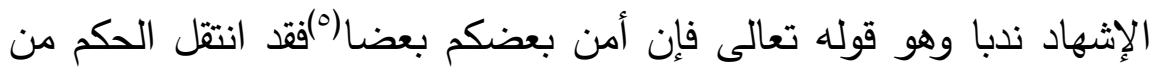

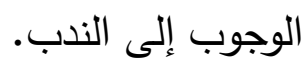

ثالثَا: ما قاله الثافعي رحمه الله: " أُمِرُوا بِالْكِتَابٍ وَالَرَّهْنِ: احَتِيَّاطًا

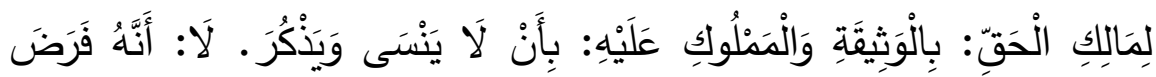

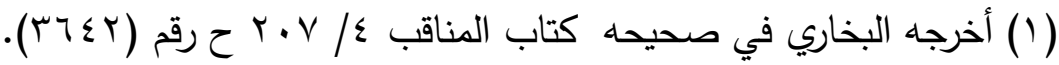

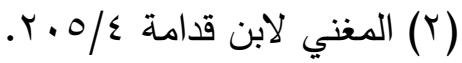

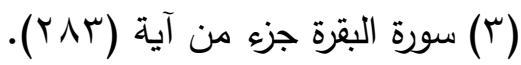

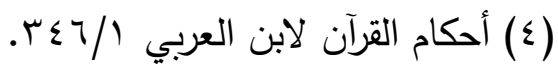

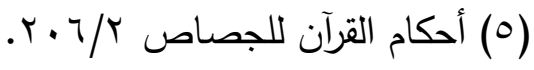




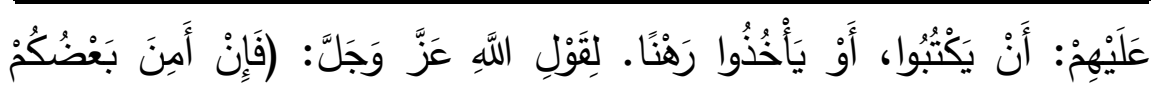

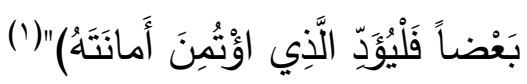

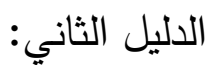

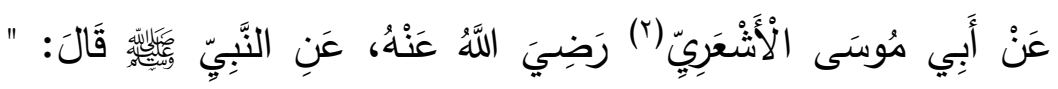

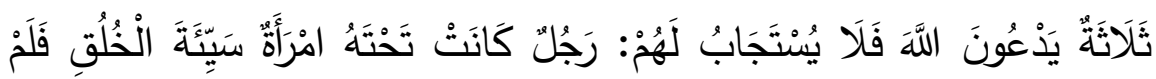

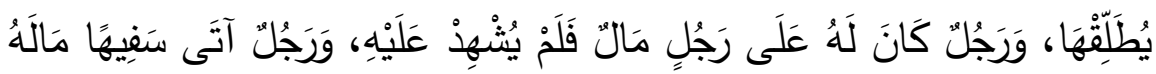

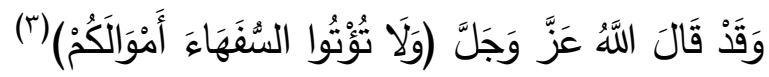

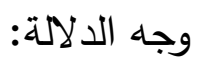

يدل هذا الحديث على أن من ترك الإشهاد فإنه يعصى الله بتركه،

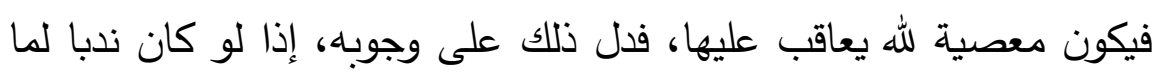
استحق تاركه العقوبة.

نوقش ذلك: بأنه ليس في الحديث ما يدل على وجوب الإشهاد .

$$
\text { وأيضا لاختلافهم في رفع الحديث ووقفه(£). }
$$

الدليل الرابع: القياس على النكاح فكما يجب الإشهاد على عقد النكاح

يجب الإثهاد على البيع ومن ثم الكتابة فتكون الكتابة واجبة(ه)

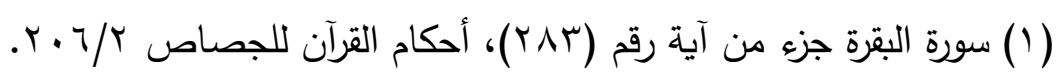

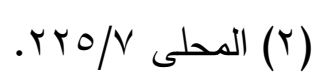

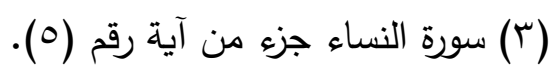

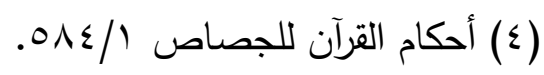

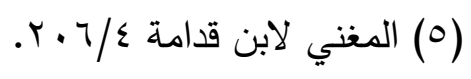




\section{توثيق الإذن الطبي دراسة فقهية مقارنة}

نوقش ذلك: بأنه قياس على النكاح قياس في مقابلة النص فلا يعتد به، وأيضًا بأن الأمر بالتوثيق بالكتابة والإشهاد فيه حرج ومشقة في كل

وقت ومع كل معاملة ('). بالنان.

أدلة أصحاب القول الثالث: - مابث

استدل القائلون بأن التوثيق مباح وهو قول أبي سعيد الخدري والحسن

والثعبي

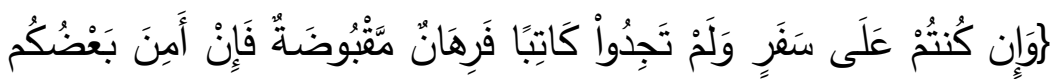

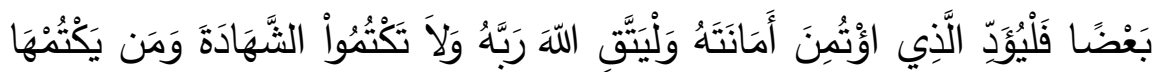

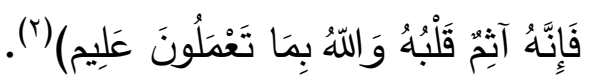

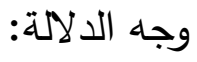

دلت الآية الكريمة على أنه متى حصل الائتمان بين المتعاملين، فإن

الواجب تأدية الحقوق وعدم الخيانة فيها وعلى ذلك فيكون الأمر بالكتابة في

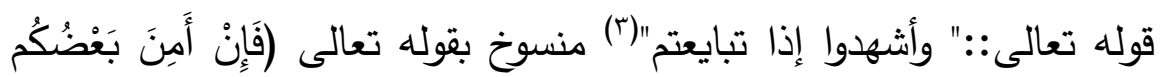

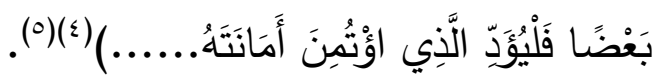

وقال القرطبي- رحمه الله-: وحكى المهدوي عن قوم أنهم قالوا:"

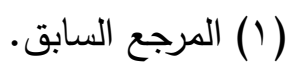

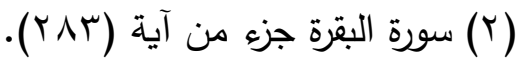

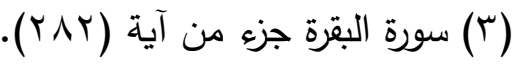

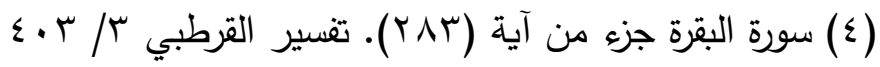

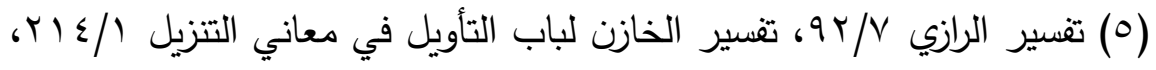


وأشهدوا إذا تبايعتم" منسوخ بقوله:" فإن أمن بعضكم بعضا". وأسنده النحاس

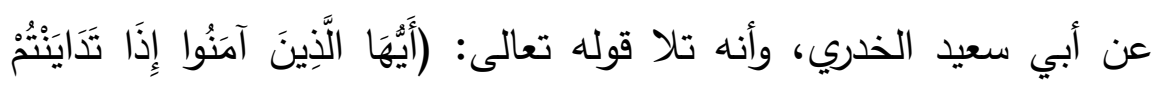

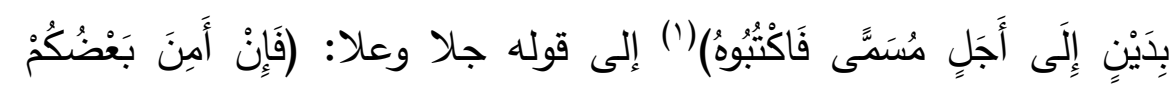

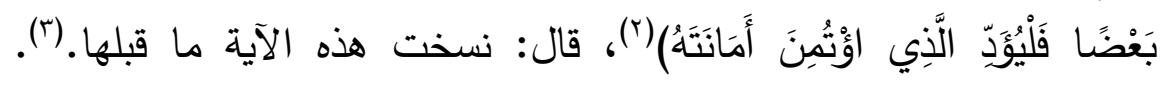
فيكون على هذا القول مما نسخ فرضه بغير فرض. بل نحن مخيرون في فعل الأول وتركه، من شاء كتب ومن شاء لم يكتب ومن شاء أشهد ومن شاء لم يشهد)؛. وقيل: الأمر بالإشهاد منسوخ بقوله تعالى: (وَأَحَلَّ اللَُّ

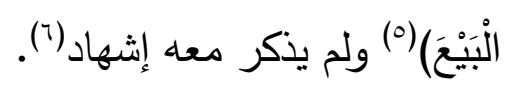

مناقشة ذلك القول: نوقش قولهم بنسخ الآية من عدة وجوه:

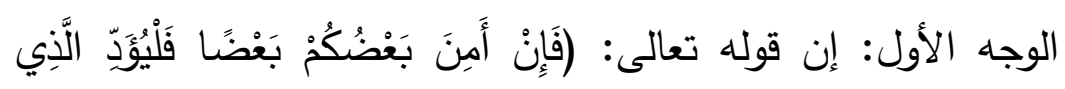

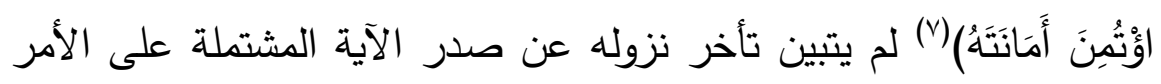

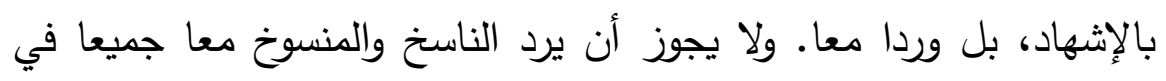

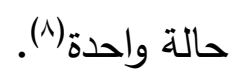

الوجه الثاني: أنه قد روى عن ابن عباس أنه لما قيل لله: إن آية

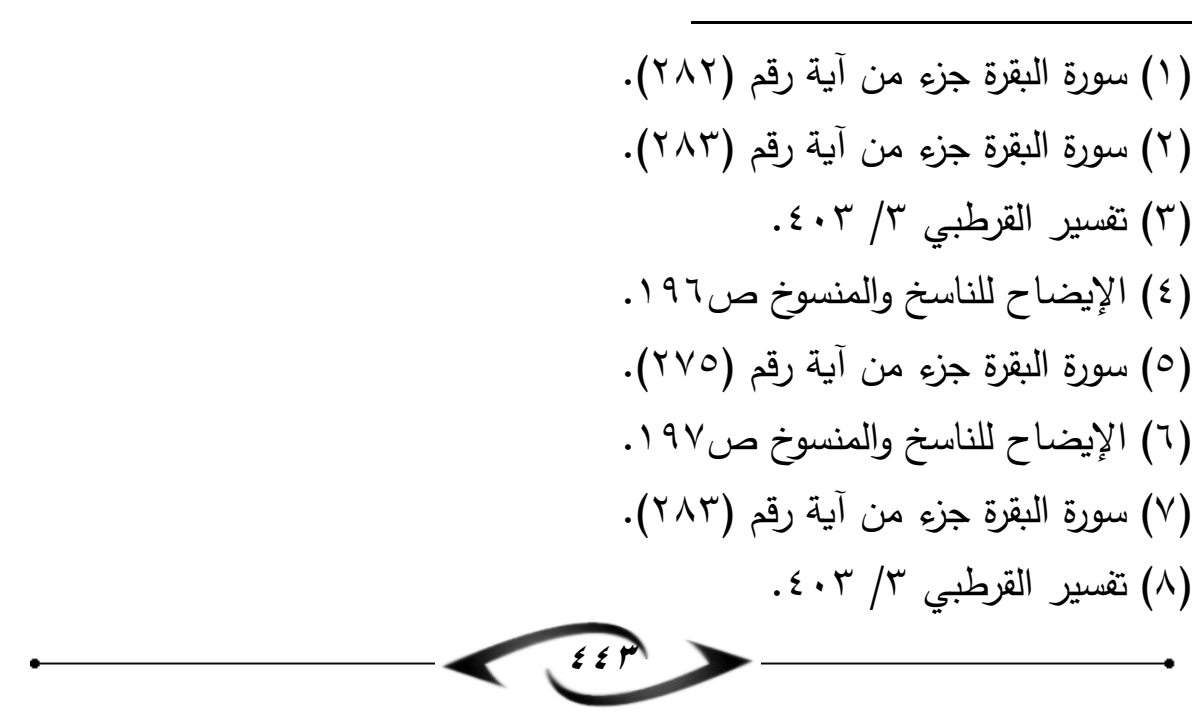




\section{توثيق الإذن الطبي دراسة فقهية مقارنة}

الدين منسوخة قال: لا والله إن آية الدين محكمة ليس فيها نسخ قال: والإشهاد إنما جعل للطمأنينة، وذلك أن الله تعالى جعل لتوثيق الدين طرقا، منها الرهن، ومنها الإشهاد('). وبذلك يظهر لنا جليا أن الآية محكمة ولم تنسخ.

الرأي المختار : يظهر لنا بعد عرض آراء الفقهاء وأدلتهم والمناقثة أن الرأي المختار هو القول الأول وهو أن التوثيق مأمور به وبخاصة فيما يتعلق بالمحافظة على المقاصد الخمسة وله أهمية وذلك لما يلي: -لقوة أدلتهم وسلامتها من المعارضـة.

- ولأن في التوثيق قطع المنازعة، ورد الحقوق، والقيام بها.

- ولاختلاف الأمور في المعاملات بين بسيطة لا تحتاج

توثيق وتكرر كل يوم وأمور ذات أهمية وهل هناك أهمبة أكثر من المحافظة على عافية أبدان الناس وصحتهم، لذا توثيق الاذن حسب المتعارف عليه في كل بلد لهو أمر ضروري مأمور به والله أعلم

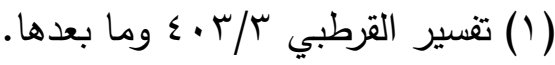




\section{المبحث السادس: \\ انتهاء توثيق الإذن الطبي}

ينتهي توثيق الإذن الطبي بما ينتهي به الإذن الطبي بما يلي: فقد

ذكر الدكتور أحمد كنعان في الموسوعة الطبية الفقهية أن الإذن ينتهي في بإني

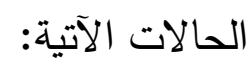

ا - بانتهاء المدة، أي بانتهاء مدة الإذن.

r- بالثفاء بأن يشفى المريض من مرضه الذي أذن للطبيب بمعالجته فيه.

r- بالموت وهو موت المريض فإن الإذن الذي صدر من المريض قبل وفاته فإنه ينتهي بموته.

؟- بانتفاء الأهلية عن المرض الذي أذن كأن يجن المريض جنونا

$$
\text { مطبقا ولا يرجى برؤه('). }
$$

0- وإلغاء توثيق ذلك الإذن ، وبنفس طريقته من شهادة أو كتابة أو غيرهما.

(1) الموسوعة الطبية الفقهية د. أحمد كنعان صاه ط. دار النفائس الطبعة

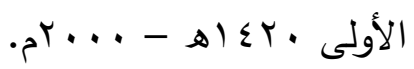


المبحث السابع

حوكمة توثيق الإذن الطبي

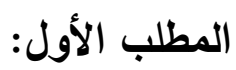

معنى الحوكمة

يعد لفظ الحَوْكَمَة من الألفاظ الحديثة في اللغة العربية، تم إقراره في القاهرة من مجمع اللغة العربية عام Y ....T، وهذه الكلمة هي ترجمةً للكلمة الإنجليزيةGOVERNANCE إذن والتي لها أكثر من معنى ولكن

$$
\text { (حَكَمَ)هو الأقرب للحوكمة }
$$

الحوكمة لغة: مشتق من الحكم ومعناه الإتقان والفصل والمنع من الظلم، والاسم الحكومة، أحكم الثيء: أتقنه. و - هـ عن الأمر: أرجعه. و السفيه: منعه عن الفساد وأخذ على يده.(') الحوكمة اصطلاحا: لا يوجد إجماع على تعريف موحد وخاص لمصطلح الحوكمة، فمن تعريفاته تعريف مؤسسة التمويل الدولية (IFC) بأنه: "النظام الذي يتم من خلاله إدارة الشركات والتحكم في أعمالها" وتعرفها منظمة التعاون الاقتصادي والتنمية: ( (OECD) (أنها: " مجموعة من العلاقات التي تربط بين القائمين على الشركة وحملة الأسهم وغيرهم من أصحاب المصالح" وهنالك تعريف آخر للحوكمة يدور حول الطريقة التي لتئي تدار بها الشركة وآلية التعامل مع جميع أصحاب المصالح فيه من عملاء الشركة والمساهمين والموظفين: (بما فيهم الإدارة التتفيذية وأعضاء مجلس الإدارة) وانتهاء بآلية تعامل الشركة مع المجتمع ككل. وأما المعنى العام ولين

(1) معجم متن اللغة ب/ 9 1 1، موقع مقال، الصحاح 1/ 19 19. 
للحوكمة، فإنها تعني وجود نظم تحكم العلاقات بين الأطراف الأساسية في الثركة (أعضاء مجلس الإدارة، الإدارة التنفيذية، المساهمين...إلخ) بهدف تحقيق الثفافية والعدالة ومكافحة الفساد ومنح حق مساءلة إدارة الثركة لحماية المساهمين والتأكد من أن الثركة تعمل على تحقيق أهدافها واستراتيجيتها طويلة الأمد. ونستتتج فيما سبق أن لتعريف الحكم في اللغة علاقة بما تهدف إليه الحوكمة الرشيدة من دفع الظلم ومحاربة الفساد وتحقيق الأهداف المنشودة في المؤسسة(').

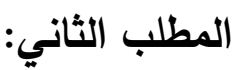
حوكمة توثيق الإذن الطبي

هي مجموعة من القوانين والنظم والقرارات التي تهدف إلي تحقيق الجودة والتميز في أداء توثيق الإذن الطبي عن طريق اختيار الأساليب المناسبة والفعالة؛ لتحقيق خطط وأهداف هذا التوثيق، كما تراقب إيجاد نظم تحكم العلاقات بين الأطراف الأساسية في توثيق الإذن الطبي والتي تؤثر في الأداء، وتثمل مقومات تقوية الجانب القانوني للمؤسسة الطبية وعلاقتها بالمرضى علي المدى البعيد، وتحديد المسؤول والمسؤولية بمحداتها الداخلية والخارجية، وتحقيق الثفافية والعدالة، وحفظا لحقوق المرضى والمنشأة

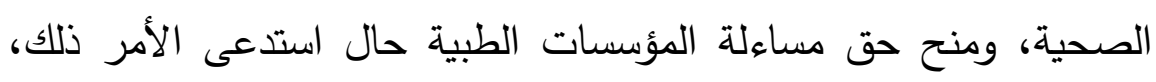
وعليه تتحقق الحماية للمرضى والكوادر الطبية مع مراعاة مصالح الأداء

(1) دور الشريعة الإسلامية في ترسيخ مباديء الحوكمة: مدى إلزامية الوعد في

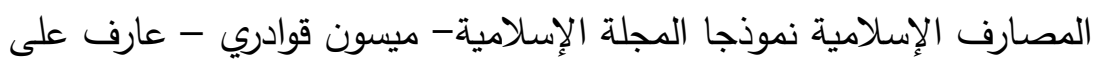
عارف- حسن الهنداوي- العالمية الماليزية - مجلة الإسلام في أسيا - المجلد

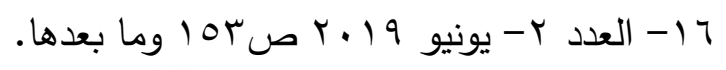


والحد من الإفراط(').

يجب أن تلم حوكمة توثيق الإذن بالإجراء الطبي بكل التفاصيل الفنية، والقانونية ومن ذلك:

1 - تقاصيل معلومات المؤسسة الطبية وأقسامها وإداراتها.

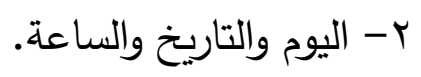
r- تفاصيل معلومات المريض. ع- تفاصيل معلومات الكادر الطبي.

0- تفاصيل معلومات الإجراء الطبي، ومضاعفاته، ومدى خطورته،

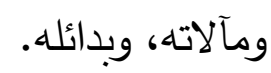

7- تفاصيل الشهود، والولي أو الوكيل أو المترجم.

- V التأكيد من إعطاء نسخة من الإذن بالإجراء الطبي للمريض.

1- أن تكون الوثيقة نموذجا رسميا أصليا خاضعا لإجراءات ضبط

الوثائق ضمن المؤسسة.

9- أن تكون صلاحية الإذن الطبي محددة.

• (- عدم جواز استعمال الاختصارات في الوثيقة(广).

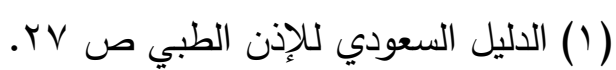

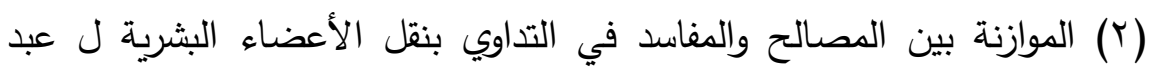

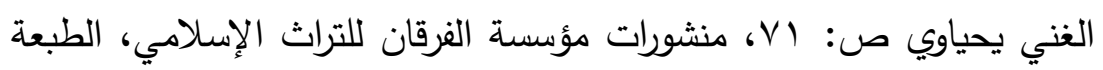

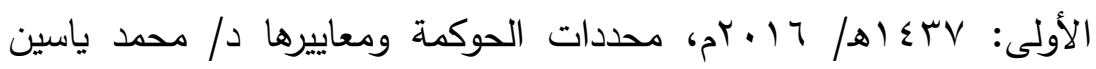

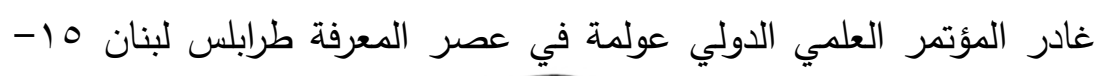




\section{الملاحق}

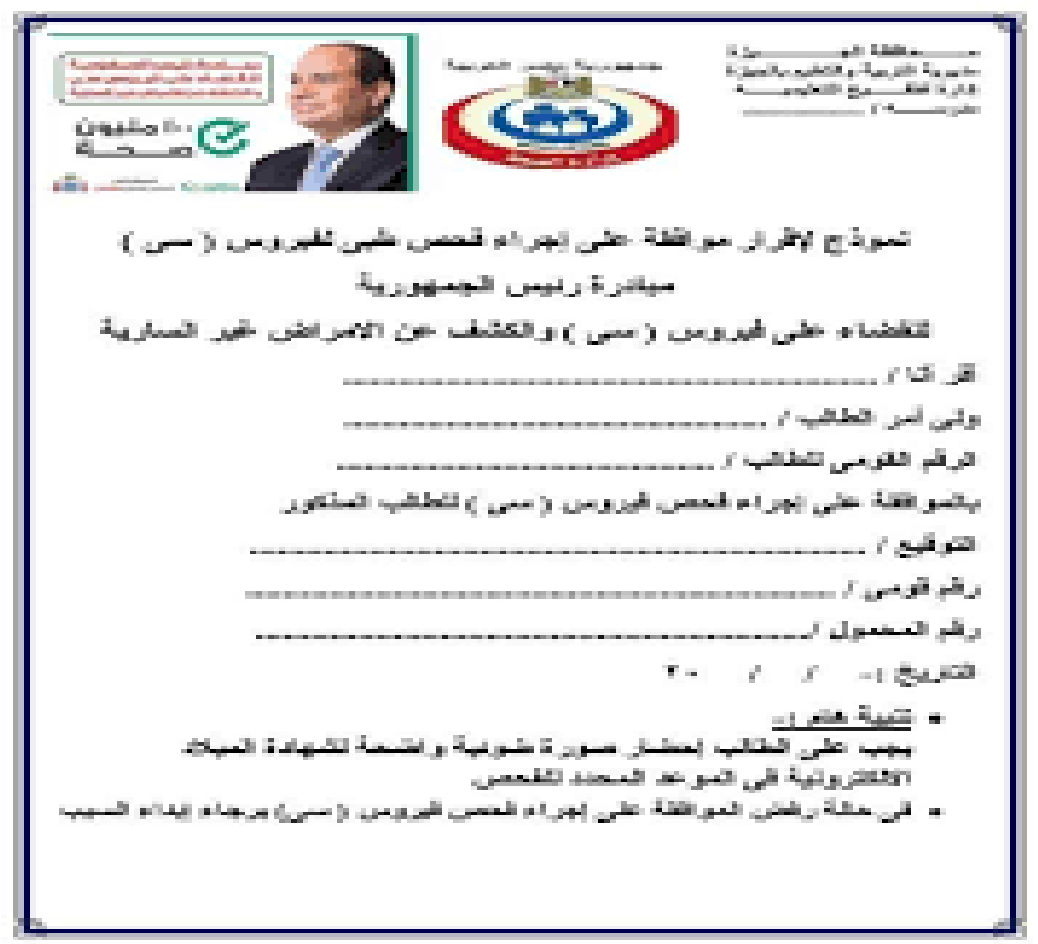

IV 


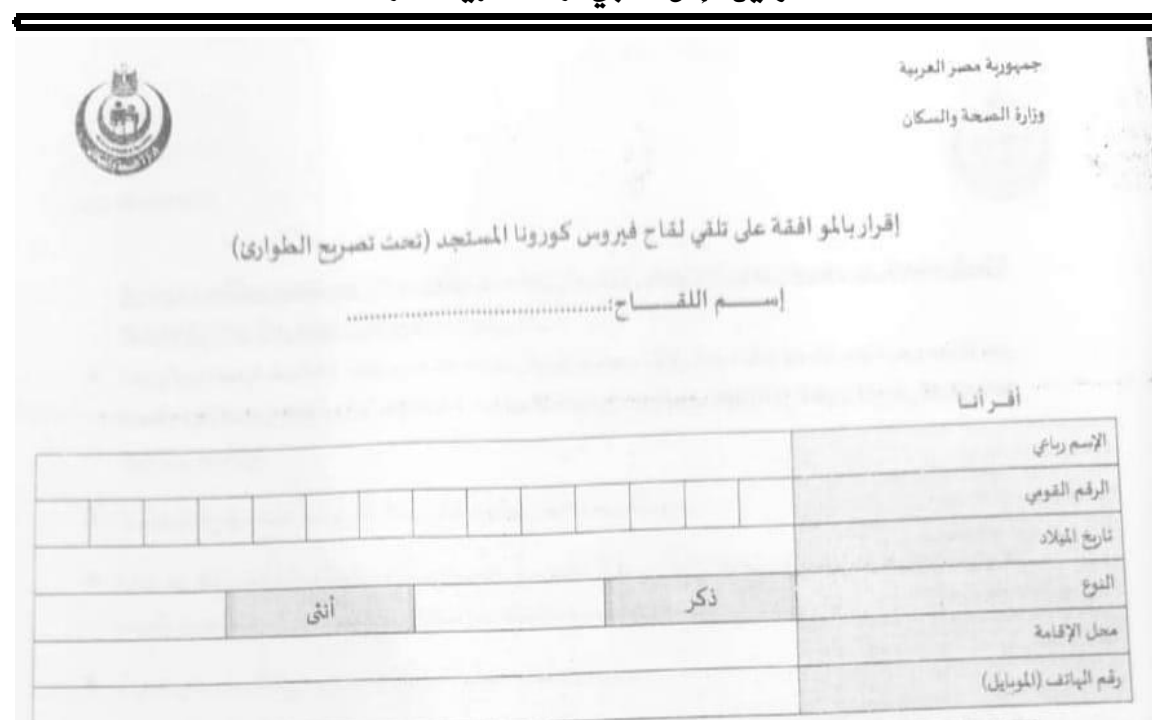

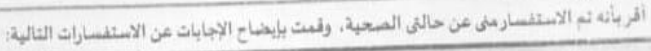

\begin{tabular}{|c|c|c|}
\hline y & نصم & 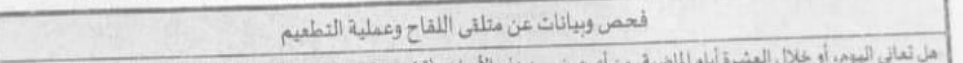 \\
\hline & & 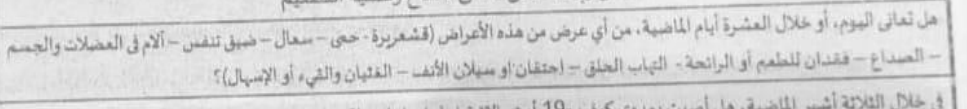 \\
\hline & & 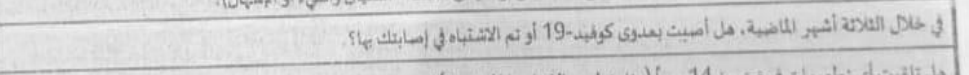 \\
\hline & & 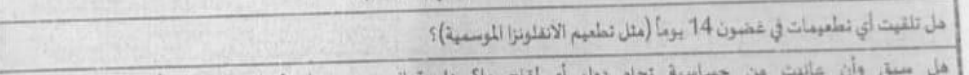 \\
\hline & & 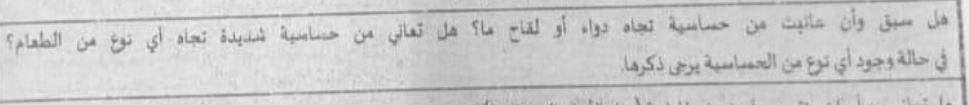 \\
\hline & & 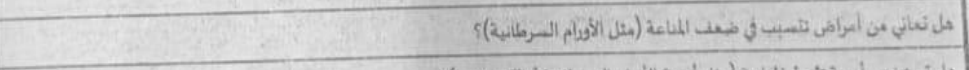 \\
\hline & & 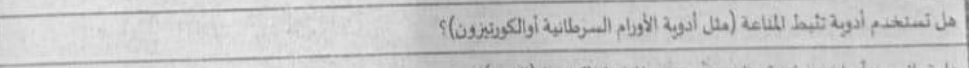 \\
\hline & & 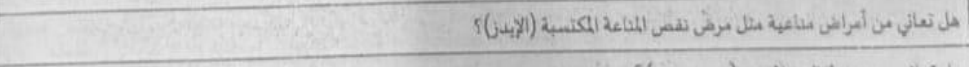 \\
\hline & & 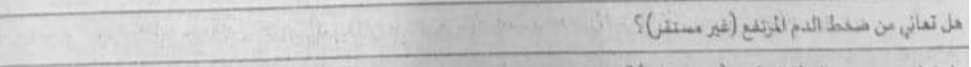 \\
\hline & & 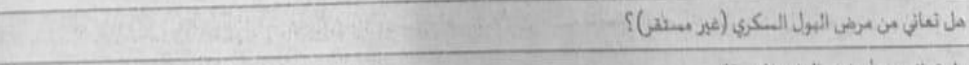 \\
\hline & & 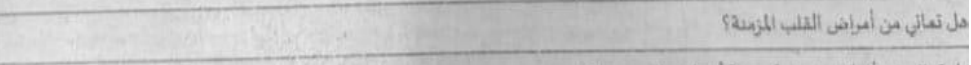 \\
\hline & & 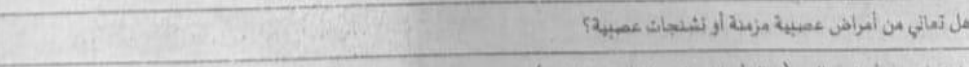 \\
\hline & & 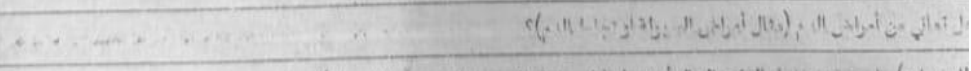 \\
\hline & & 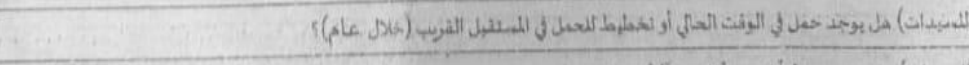 \\
\hline & & 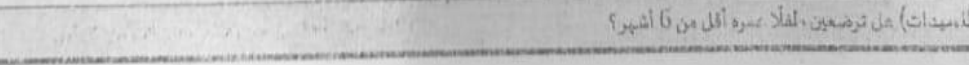 \\
\hline
\end{tabular}




\section{الخاتمة}

الحمد لله حمدًا كثيرًا طيبًا مباركًا فيه على ما منَّ عليَّ من نعم، وبعد: فقد توصلت من خلال البحث إلى النتائج التالية: ا- التوثيق: هو مجموعة من العقود الثرعية المحكمة؛ لتأكيد الحق واستقراره في يد صاحبه، أو في ذمة غيره، أو إثباته عند التازع أمام القضاء.

ץ- الإذن الطبي: هو إقرار المريض بالموافقة على إجراء ما يراه الطبيب مناسبا له؛ من كثف سريري، وتحاليل مخبرية، ووصف دواء، وغيره من الإجراءات الطبية التي تلزم لتشخيص المرض وعلاجه. r- الإذن الطبي عقد بين الطبيب والمريض، يتعهد الطبيب بموجبه أن يعالج المريض وفق الأصول المتعارف عليها عند أهل الطب، وهو ما يعرف بالإقرار الطبي.

ع - يلزم الطبيب فتح ملف طبي للمريض يرجع إليه وهو وثيقة رسمية سرية.

0- توثيق الإذن الطبي هو: "الأخذ بجميع الوسائل والإجراءات التي تضبط إذن المريض، وتضمن الحقوق، وتتظم العلاقة بين المريض ومقدمي الخدمة الطبية، وتوضع في ملف المريض سواء كان ورقيا أو إلكترونيا ويتم الرجوع إليه عند الحاجة". ج- للإذن الطبي أنواع متعددة باعتبارات مختلفة، فهو من حيث دلاته ينقسم إلى صريح وغير صريح، ويتتوع باعتبار طرق التعبير عنه إلى إذن 


\section{توثيق الإذن الطبي دراسة فقهية مقارنة}

لفظي وإذن بالإثارة، كما يتنوع باعتبار كتابته إلى كتابي وشفهي، ويتوع باعتبار موضوعه إلى إذن مطلق ومقيد.

$$
\text { V- للتوثيق الطبي نوعان: عرفي ورسمي. }
$$

1- طرق التوثيق الثرعية عند الفقهاء أربعة هي: الكتابة، والثهادة

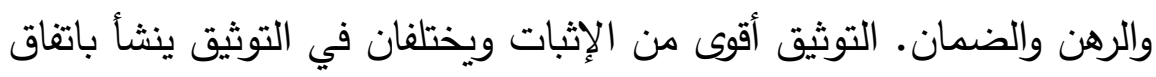

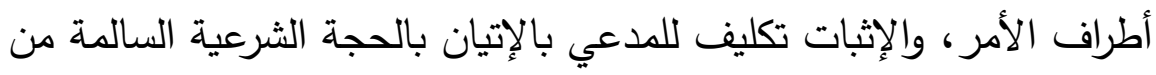
المطاعن. التوثيق والإثبات متغايران في معظم الطرق المؤدية لكل منهما. 9- وسائل التوثيق والتسجيل الطبي إما الكتابة أو الثهادة سواء

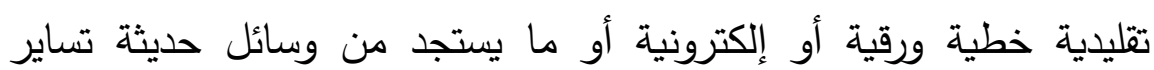
التطور التكنولوجي في كل عصر. • 1- كتابة الوثائق من فروض الكفايات. 11- لكتابة الوثائق أهمية كبيرة في حفظ الحقوق، وسد أبواب

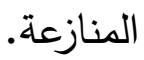

r ا - يشترط في الموثق أن يكون مسلما مكلفا عدلا وافر العقل عالما

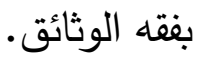
با - يشترط في الإذن الطبي صادرا من أهله، مأذون به، مشروعا، محددا. بلفظ صريح أو شبهه. ع ا- الإذن الطبي يأخذ حكم التداوي. 10 - وجوب توثيق الإذن الطبي من باب حفظ الحقوق. 17 - ينتهي توثيق الإذن الطبي يما ينتهي به الإذن الطبي. 
VV V الحوكمة في توثيق الإذن الطبي: هي مجموعة من القوانين والنظم والقرارات التي تهدف إلي تحقيق الجودة والتميز في أداء توثيق الإذن الإن

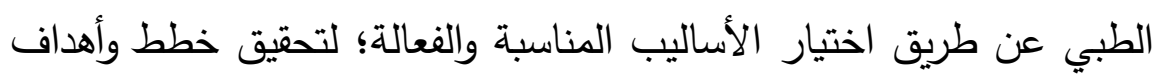
هذا التوثيق.

9 ا - يجب أن تلم حوكمة توثيق الإذن بالإجراء الطبي بكل التفاصيل

الفنية، والقانونية لتوثيقه.

** $\quad * * \quad * *$

\section{التوصيات}

أوصي الباحثين بدراسة موضوع التوثيق الصحي وأثره والضمان فيه،

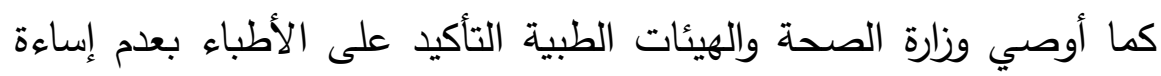
استخدام الإذن الطبي ومحاسبة المقصرين، ووضع قواعد بيانات إلكترونية جديدة لجميع مواطني الدولة، ومحاصرة الهيئات الطبية الفاسدة ومعاقبتها. * * $\quad *$ * * * 


\section{توثيق الإذن الطبي دراسة فقهية مقارنة}

\section{فهرس المراجع}

$$
\text { ثأولاً: القرآن الكريم. ثبت المراجع: }
$$

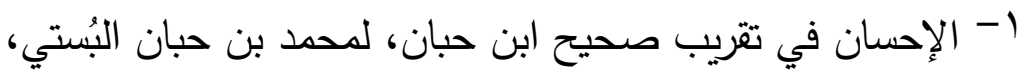

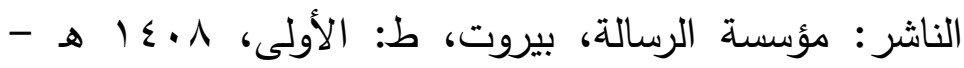

$$
\text { م } 1911
$$

ץ- أحكام الإذن الطبي د. عبد الحمن الجرعي منشور على موقع

$$
\text { مداد . مان }
$$

ץ- أحكام القرآن لعلي أبو الحسن الطبري، المعروف بألكيا الهراسي

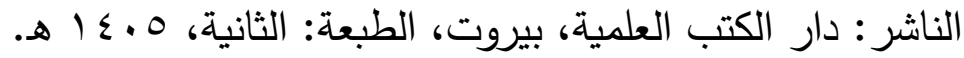

ع- أحكام القرآن للثافعي - جمع البيهقي، لأحمد بن الحسين أبو

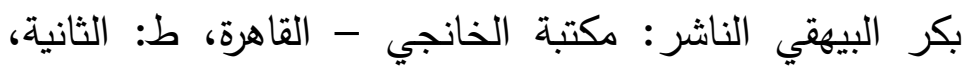

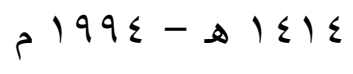

0- أحكام القرآن: لأحمد بن علي أبو بكر الرازي الجصاص الحنفي צ- أحكام القرآن، لمحمد بن عبد الله المالكي الناشر: دار الكتب

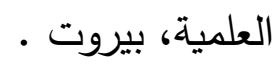

V- أحكام أهل الذمة لمحمد ابن قيم الجوزية ، رمادي للنشر ،

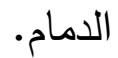

1- أدب القاضي، لأبو العباس الطبري المعروف بابن القاص،

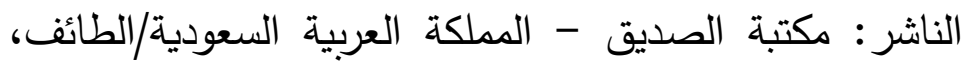




$$
\text { الطبعة: الأولى، 9. } 9 \text {. هـ - } 1919 \text { 19 م. }
$$

9- الإذن الطبي في الحالات الطارئة لمحمد بن مطر السهلي

$$
\text { بمجلة كلية الثريعة بطنطا العدد (ب). }
$$

• ا- الإذن في إجراء العمليات الطبية أحكامه وأثثه د هاني الجبير،

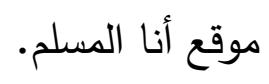

11- الإذن في الجراحات المستعجلة د. عصام محمد سليمان موسى، ثبت كامل في مجلة مجمع الفقه الإسلامي الدورة التاسعة عشرة

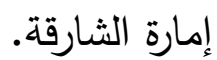

r إرواء الغليل في تخريج أحاديث منار السبيل،للألباني، الناشر:

$$
\text { المكتب الإسلامي - بيروت، ط: ب 0. ـ 1 هـ - } 1910 \text { (م. }
$$

rا- الاستذكار لابن عبد البر سالم محمد عطا، محمد علي

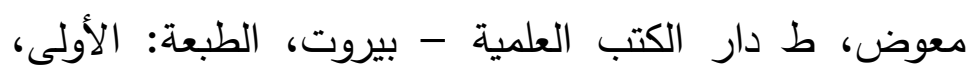

$$
\text { .r...- } \mid \leqslant r_{1}
$$

ع ا- أسد الغابة، المؤلف: أبو الحسن الثيباني الجزري، عز الدين

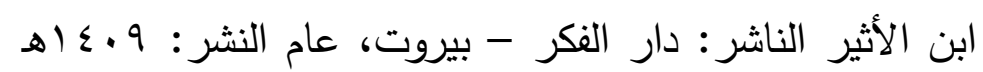

$$
\text { م) } 919-
$$

1 - الأَصْلُ، لأبي عبد الله بن فرقد الثيباني الناشر : دار ابن حزم،

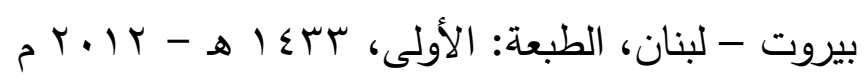

7 ا 1 - إعلام الموقعين عن رب العالمين، لابن قيم الجوزية الناشر : دار

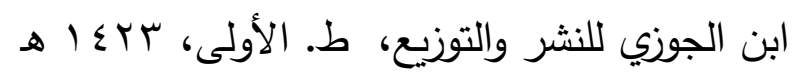




\section{توثيق الإذن الطبي دراسة فقهية مقارنة}

IV الأعلام، المؤلف: خير الدين بن علي بن فارس، الزركلي

الامشقي الناشر : دار العلم للملايين، الطبعة: الخامسة عشر -

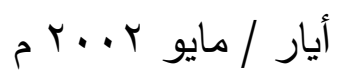

$$
\text { 11 - الأم للشافعي الناشر : دار المعرفة - بيروت }
$$

9 1 - الإنصاف في معرفة الراجح من الخلاف للمرداوي الناشر هجر

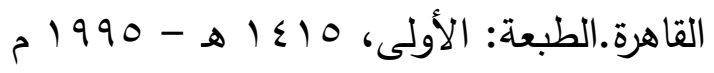

• ץ- أنوار التنزيل وأسرار التأويل، المؤلف: ناصر الدين الثيرازي البيضاوي ،الناشر : دار إحياء التراث العربي - بيروت، الطبعة:

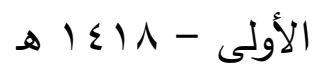

اب - الإيضاح لناسخ القرآن ومنسوخه لمعرفة أصوله واختلاف الناس فيه لأبي محمد القيسي تحقيق د/ أحمد حسن فرحات دار

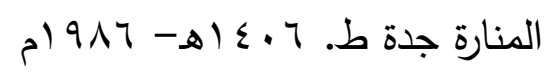

r

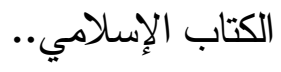

$$
\text { rr- البحر الزخار لابن المرتضى من دون طبعة. }
$$

گ צ- بحر المذهب (في فروع المذهب الثافعي)، المؤلف: الروياني، أبو المحاسن عبد الواحد بن إسماعيل ، الناشر: دار الكتب

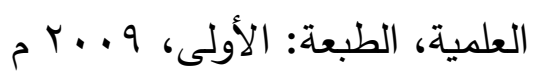

0Y- بدائع السلك في طبائع الملك، لمحمد الأندلسي، أبو عبد الله، شمس الدين الغرناطي ابن الأزرق ، وزارة الإعلام - العراق، 
جr- بدائع الصنائع في ترتيب الشرائع، لعلاء الدين الكاساني الحنفي

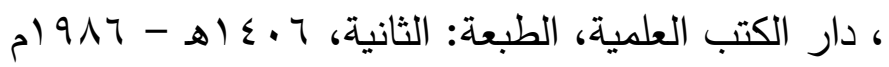

V V - البيان في مذهب الإمام الثافعي، لأبو الحسين العمراني اليمني

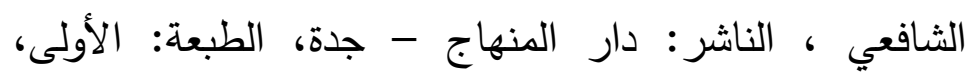

$$
\text { م } r . . .-\Delta|\leq r|
$$

^ץ- البيان والتحصيل والشرح والتوجيه والتعليل للمسائل المستخرجة، لأبو الوليد القرطبي الناشر : دار الغرب الإسلامي، بيروت، ط.:

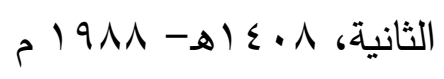

qץ- بين الثريعة والقانون نظرات في توثيق المعاملات المالية، عبد اللطيف السبكي، مجلة الأزهر، المجلد العشرون عدد المحرم

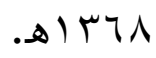

• ب- التاج والإكليل لمختصر خليل، لمحمد بن يوسف العبدري الغرناطي، المالكي دار الكتب العلمية، ط: الأولى، 71 إ؛ (هـ-

$$
\text { - ) } 99 \leqslant
$$

اب- تبصرة الحكام في أصول الأقضية ومناهج الأحكام لابن

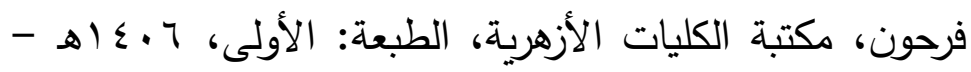

$$
\text { . ) } 917
$$

ץr- تحفة المودود بأحكام المولود لابن قيم الجوزية،الناشر : مكتبة

$$
\text { دار البيان - دمشق بودود }
$$

بr- تزوير المحررات رسالة دكتوراة لعلي بن خميس الزهراني بجامعة

$$
\text { أم القرى ^ץ ــ ا. }
$$




\section{توثيق الإذن الطبي دراسة فقهية مقارنة}

ع ب- التعريفات الفقهية للبركتي،الناشر: دار الكتب العلمية ط:

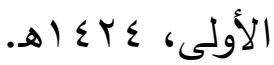

هـ- تفسير البغوي، دار طيبة للنشر والتوزيع، الطبعة: الرابعة، . $199 V-8 \mid \leqslant 1$

צب- تفسير الطبري = جامع البيان، الناشر: مؤسسة الرسالة، ط:

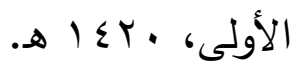

V V- تفسير القرآن الحكيم (تفسير المنار)، لمحمد رشيد بن علي رضا القلموني الحسيني الناشر: الهيئة المصرية العامة للكتاب، سنة

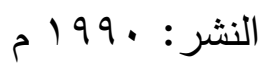

^ץ- تفسير مقاتل بن سليمان، لأبو الحسن مقاتل الأزدي البلخى، الناشر: دار إحياء التراث - بيروت، ط: الأولى - بrع ا هـ.

q العسقلاني ،الناشر : دار الكتب العلمية، الطبعة: الطبعة الأولى

$$
\text { . 19人9. هـ (1) } 19
$$

• ع- تهذيب التهذيب، لابن حجر العسقلاني، الناشر: مطبعة دائرة

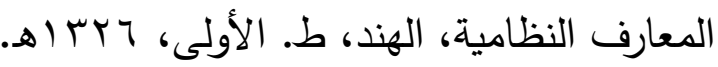
اء- توثيق الديون في الفقه الإسلامي د. صالح الهليل، وزارة التعليم

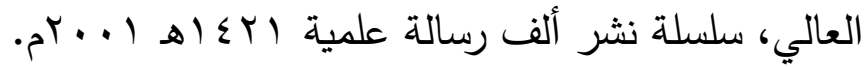
rی- التوثيق بالكتابة في الفقه الإسلامي عبد الله حمد إبراهيم المشعل، وتطبيقاته المعاصرة رسالة ماجستير جامعة الملك اك به

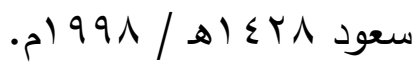


بـ- توضيح الأحكام شرح تحفة الحكام، المؤلف: عثمان بن المكي التوزري الزبيدي، الناشر: المطبعة التونسية، الطبعة: الأولى، لوحن،

\section{q}

؟ - التوقيف على مهمات التعاريف، لزين الدين الحدادي ثم المناوي

القاهري (الناشر: عالم الكتب مب عبد الخالق شروت-القاهرة ،

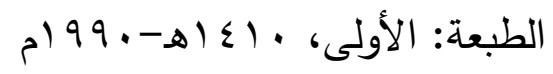

0ـ- تيسير الكريم الرحمن في تقفير كلام المنان، لعبد الرحمن بن ناصر بن عبد الله السعدي الناشر: مؤسسة الرسالة، الطبعة:

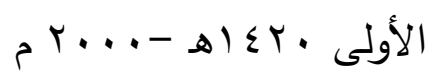

؟ - ثقات، لمحمد بن حبان لدارمي، البُستي (الناشر : دائرة المعارف

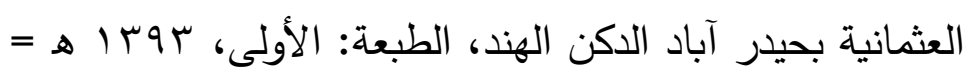

$$
.19 V T
$$

§V

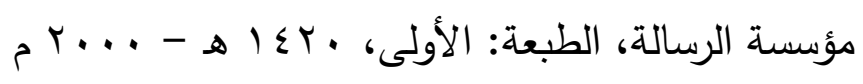

^ـ- الجامع لأحكام القرآن = تفسير القرطبي، الناشر: دار الكتب

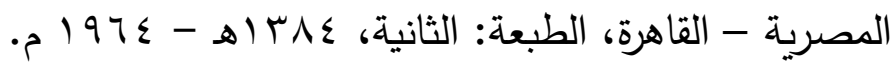

9؟- حاشية الروض المربع شرح زاد المستقنع، النجدي، الطبعة:

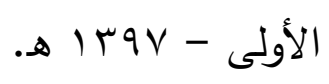

$$
\text { •- حاشيتا قليوبي وعميرة، الناشر : دار الفكر - بيروت. }
$$

10- الحاوي الكبير في فقه مذهب الإمام الثافعي وهو شرح مختصر المزني بالماوردي ط: دار الكتب العلمية، بيروت، ط: الأولى، 


$$
.81999-\& 1 \leqslant 19
$$

ror- الحدود الأنيقة والتعريفات الدقيقة زكريا أبو يحيى السنيكي،

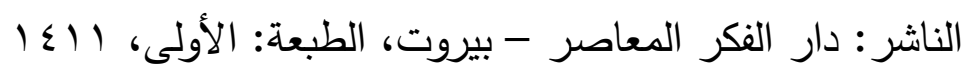
rه- حلية الأولياء وطبقات الأصفياء للأصفهاني - دار الكتب

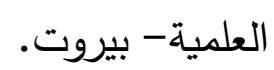

؟ه- الدر المختار وحاشية ابن عابدين رد المحتار ط. دار الفكر،

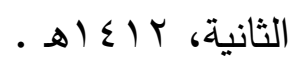

00- الدليل الطبي السعودي للإذن الطبي الصادر عن وزارة الصحة

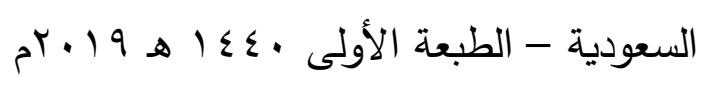

7ه- الذخيرة، المؤلف: أبو العباس المالكي الثهير بالقرافي ، الناشر: دار الغرب الإسلامي- بيروت، الطبعة: الأولى، ـ99 19 م

OV الناشر: دار الكتب العلمية - بيروت،الطبعة: الأولى، 0 اء اله. ^ه- الروض المربع شرح زاد المستقتع للبهوتي دار المؤيد - مؤسسة

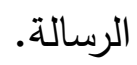

9ه- روضة الطالبين وعمدة المفتين، للنووي المكتب الإسلامي،

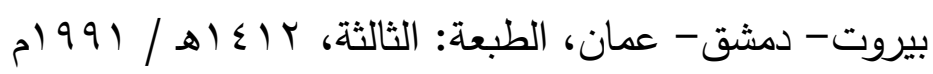
• 7- سنن ابن ماجه ط. دار الرسالة العالمية، الطبعة: الأولى،

$$
r .9-\text { - ه } 1 \leqslant r \text {. }
$$

آ- سنن أبي داود، الناشر: دار الرسالة العالمية، الطبعة: الأولى، 


\section{. $1 \leqslant \mu$.}

rا7- سنن الترمذي لأبو عيسى الناشر: شركة مكتبة ومطبعة

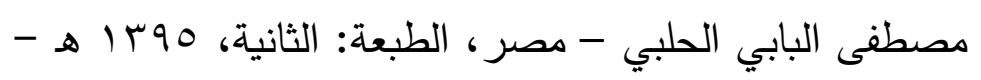
$.19 \times 0$

rا7- سنن الدارقطني، الناشر: مؤسسة الرسالة، بيروت - لبنان، ط:

$$
\text { الأولى، }
$$

§ ا- السنن الكبرى،أبو بكر البيهقي الناشر: دار الكتب العلمية،

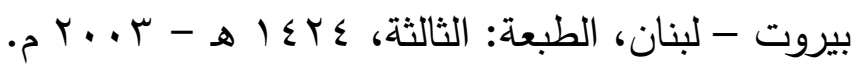

$$
\text { 0- شرائع الإسلام للحلي من دون طبعة }
$$

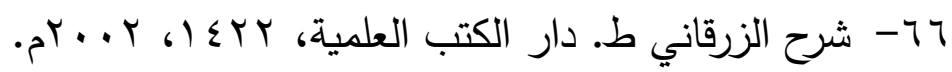

V7 - شرح كتاب النيل لمحمد أطفيش ط. مكتبة الإرشاد بجدة ودار

$$
\text { الفتح بيروت }
$$

11- صبح الأعشى في صناعة الإنشاء، المؤلف: أحمد بن علي بن أحمد الفزاري القلقشندي ثم القاهري الناشر: دار الكتب العلمية،

$$
\text { بيروت. }
$$

99- الصحاح تاج اللغة وصحاح العربية، المؤلف: أبو نصر إسماعيل بن حماد الجوهري الفارابي ، الناشر: دار العلم

$$
\text { للماليين - بيروت }
$$

• • صــيح البخـاري ،الناشـر : دار طـوق النجـاة (مصــورة عـن السـلطانية بإضــافة تـرقيم محمـــ فؤاد عبـد البـاقي)، الطبعـة: 


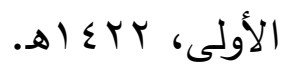

1 - صحيح مسلم ، الناشر : دار إحياء التراث العربي - بيروت. VY الطب النبوي أبو نعيم أحمد بن عبد الله بن أحمد بن إسحاق بن

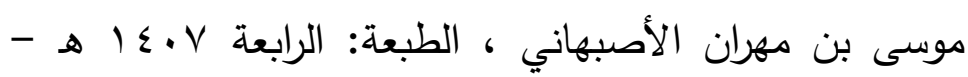
. 19人V

rV - طرح التثريب في شرح التقريب للعراقي الطبعة المصرية القديمة. ؟ - - طرق الإثبات الثرعية للشيخ: أحمد إبراهيم والمستشار : واصل

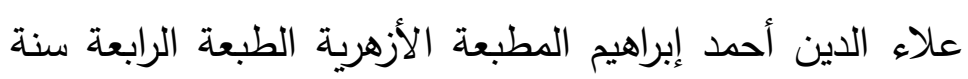
.r...

0V- الطرق الحكمية في السياسة الشرعية لأبي عبد الله، دار عالم

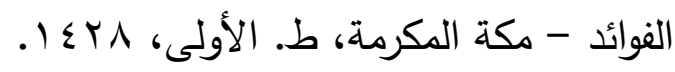

T VT- العزيز شرح الوجيز المعروف بالشرح الكبير، المؤلف: عبد الكريم بن عبد الكريم، الناشر: دار الكتب العلمية، بيروت -

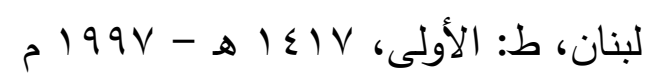

- VV

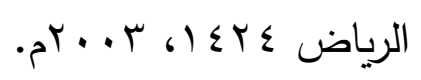

- VA

$$
\text { إحياء التراث العربي. }
$$

 • ^- فتاوى الطب والمرضى، تم جمعه من: فتاوى محمد بن إبراهيم 
آل الثيخ رحمه الله، وابن باز رحمه الله، ومشايخ اللجنة الدائمـة

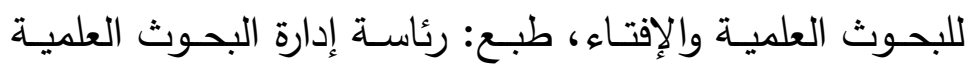
والإفتاء.

ا 1- الفتاوى الكبرى لابـن تيميـة، دار الكتب العلميـة، ط: الأولى،

$$
.19 \wedge v-8 \varepsilon \cdot \Lambda
$$

rی للساعاتي الناشر : دار إحياء التراث العربي.

بی- الفروق أنوار البروق في أنواء الفروق لأبي العباس القرافي،

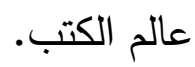

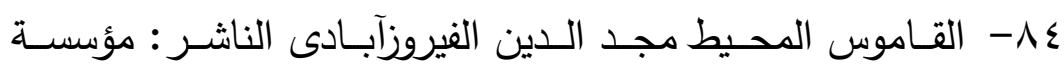
الرسـالة للطباعـة والنشــر والتوزيـع، بيـروت - لبنـان، الطبعـة:

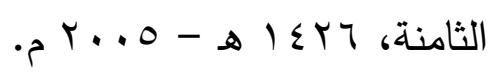

10 - القواعد النورانية الفقهية، لابن تيمية الحراني الحنبلي الدمشقي الناشر : دار ابن الجوزي، بلد النشر : المملكة العربية السعودية T1 - القوانين الفقهية لأبي القاسم، محمد بن أحمد بن محمد بن عبد

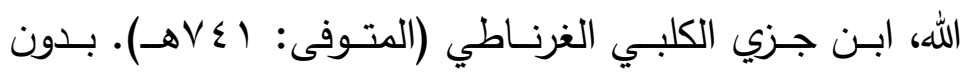
طبعة. - NV الكافي في فقه الإمام أحمد، لابن قدامة المقدسي ، الناشر : دار

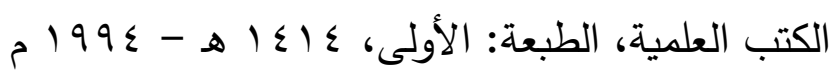
^^- كتاب الأكياء، المؤلف: جمال الدين أبو الفرج عبد الرحمن بن علي بن محمد الجوزي (المتوفى: V9هـه)، مكتبة الغزال. 


\section{توثيق الإذن الطبي دراسة فقهية مقارنة}

199- كتاب الأموال، لأبي عُبيد البغدادي ط. دار الفكر. - بيروت

9- كتاب التعريفات، لعلي الجرجاني دار الكتب العلمية بيروت -

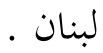

1- الكتاب المصنف في الأحاديث والآثار لابن أبي شيبة، الناشر:

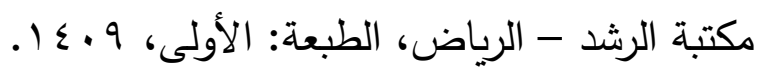
ب9- كثـاف القنـاع عن مـتن الإقنـاع، للبهوتى الحنبلى (المتوفى: $(\$) .01$

بو- كفايـة النبيـه في شرح التببيه، المؤلف: أحمد الأنصـاري، أبو العباس، نجم الدين، المعروف بابن الرفعة ، الناشر : دار الكتب

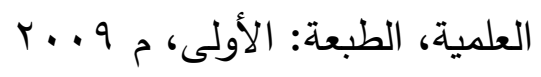

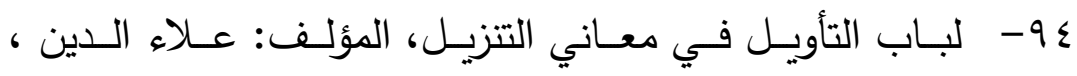
المعـروف بالخـازن ، الناشـر : دار الكتب العلميـة - بيـروت،

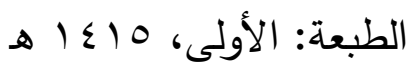

90- لسـان الحكام في معرفـة الأحكام، لابن الثِّحْنَة الثَقفي الحلبي

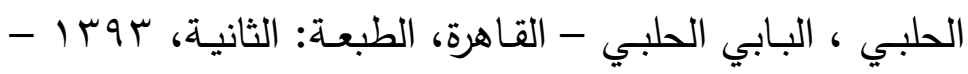
$.19 V T$

9 - لسان العرب لابن منظور دار صادر - بيروت ـ الطبعة: الثالثة . $) \leq 1 \leq-$

، V

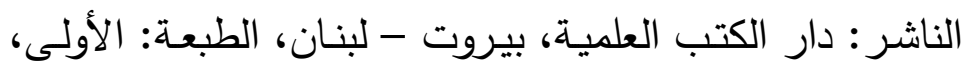




$$
\text { ? 199V-ه 1 } 111
$$

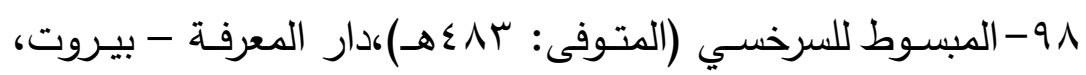
دون طبعة.

99 - مجلة الأحكام العدلية، للجنة مكونـة من عدة علماء وفقهاء في الخلافة العثمانية، الناشر : نور محمد، كارخانـه تجارتِ كتب، البه

$$
\text { آرام باغ، كراتثي. }
$$

. . . مجلـة البحث العلمي والتـراث الإسـلامي - الصـادرة عن كليـة الثريعة والدراسـات الإسـلامية التابعة لجامعة أم القرى - العدد الإسلي السادس.

1 ( ا - مجلة الجامعـة الإسـلامية بالمدينـة النبويـة ، منشور على موقع

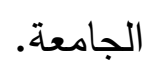

r • ا - مجلة مجمع الفقه الإسـلامي. التي تصدر عن منظمة المؤتمر

$$
\text { الإسلامي بجدة. }
$$

ץ. 1- مجموع الفتاوى، لابن تيمية الحراني ، الناشر : مجمع الملك فهد لطباعـة المصـحف الشـريف، المدينـة النبويـة، المملكـة العربيـة

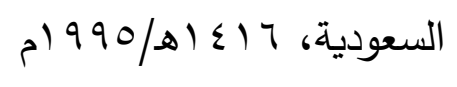

ـ • ـ - المجموع شرح المهذب للنووي (مـع تكملة السبكي والمطيعي))

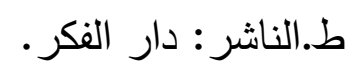

ه 1 - مجموعـة الرسـائل والمسـائل، لابن تيميـة الحراني، الناشـر : دار

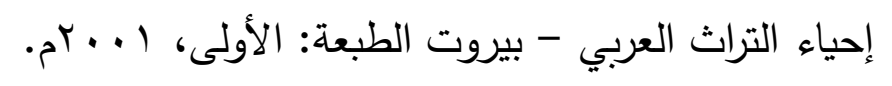




\section{توثيق الإذن الطبي دراسة فقهية مقارنة}

7 ـ ا 1 - المحكم والمحيط الأعظم،المؤلف: أبو الحسن علي بن إسماعيل بن سيده المرسي [ت: م0^ءه]. دار الكتب العلمية .

V • ا - المحلى بالآثار ،لأبي محمد علي بن أحمد بن سعيد بن حزم

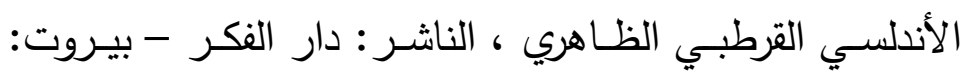
بدون طبعة وبدون تاريخ

^ • ا - المــخل الفقهي العـام دار الفكر بيـروت مصـورة طبعـة دمشقق ? 1971

9 • 1 - المدونـة للإمـام مالك بـن أنس بـن مالك بن عـامر الأصسبحي

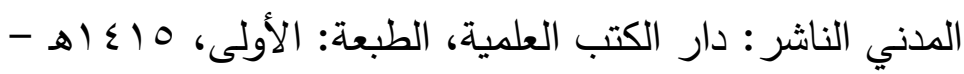
$.199 \varepsilon$

• 11- المرشد إلى الصكوك الحقوقية، د.محمد أحمد العمر ، مطبعة

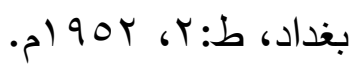

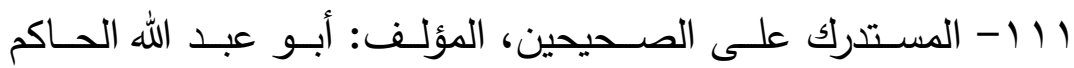

النيسابوري المعروف بابن البيع ، الناشر : دار الكتب العلمية -

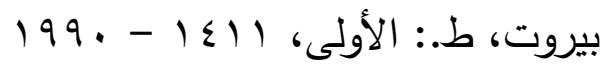

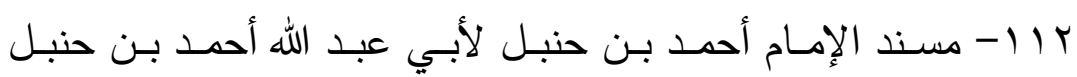

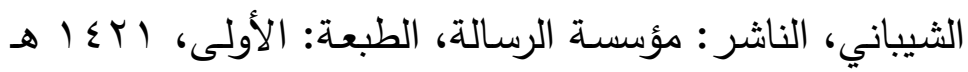

$$
\text { . } r \text {. 1 - }
$$

سا 1 - المسؤولية الطبية وأخلاقيات الطبيب د. محمد على البار . دار

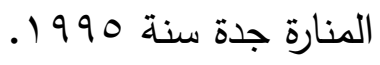

ع 11 - مصباح الزجاجة للبوصيري الناشر دار الكتب العربية الطبعة 


\section{الثانية 0 . ع أه.}

11 - المصباح المنير في غريب الشرح الكبير، للفيومي ثم الحموي، أبو العباس ، الناشر : المكتبة العلمية - بيروت.

71 1/ المصنف لأبي بكر الصنعاني الناشر : المجلس العلمي ، الهند،

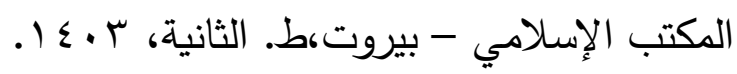
IV - IV معالم السـن للخطـابي لمطبعـة العلميـة - حلب، ط. الأولى ه 1101

11 ا- معجم اللغة العربية المعاصرة، د أحمد مختار عبد الحميد عمر

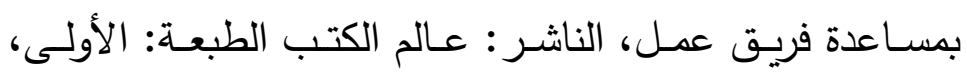

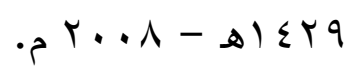

9 11 - المعجم الوسيط لمجهـع اللغـة العربيـة بالقـاهرة، الناشـر : دار الدعوة.

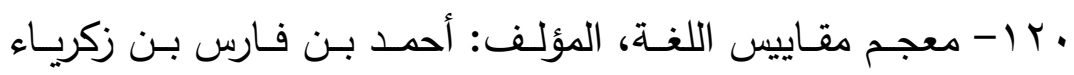
القزويني الرازي، أبو الحسين ، الناشر : دار الفكر، عام النشر :

$$
\text { . 19V9 - ه1 } 199
$$

| ا ا - معـين الحكـام فيمـا يتـردد بـين الخصـمين مـن الأحكـام،لأبي الحسن، علاء الدين، علي بن خليل الطرابلسي الحنفي ط. دار

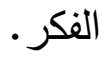

r Y I - مغني المحتاج شمس الدين، محمد بـن أحمد الخطيب الثـربيني الثـافعي (المتوفى: 9VVهـ)، الناشـر : دار الكتب العلمية، الطبعـة:

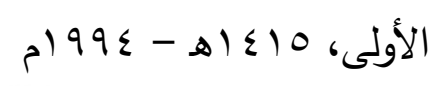




\section{توثيق الإذن الطبي دراسة فقهية مقارنة}

سب ا- - المغنـي لابـن قدامـة ،الناشـر : مكتبـة القـاهرة، تـاريخ النشـر :

$$
.1971 \text { - هITAN }
$$

؟ ا - مفاتيح الغيب = التفسير الكبير ، للفخر الدين الرازي، الناشر :

دار إحياء التراث العربي - بيروت، الطبعة: الثالثة - . بـ أهـ.

0 ا - المنثور في القواعد الفقهية، لأبو عبد الله، الناشر : وزارة الأوقاف

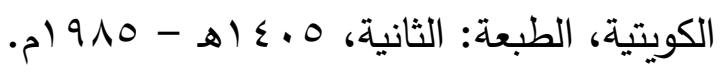

דr ا- - منح الجليل شرح مختصر خليل، لمحمد عليش، الناشر : دار

الفكــر - بيــروت، الطبعــة: دون طبعـــة، تــاريخ النشـــر :

$$
\text { . }) 919 / 81 \leqslant .9
$$

r I I - المنخول من تعليقات الأصول للغزالي، الناشر دار الفكر بيروت

$$
\text { الطبعة: الثالثة، } 9 \text { (1 1 هـ - 1991 19 م. }
$$

^ץ ا - منهاج السنة النبويـة في نقض كلام الثيعة القدرية، لابن تيمية ، الناشر : جامعة الإمام محمد بن سعود الإسلامية.

و ا ا - المنهاج شرح صحيح مسلم بن الحجـاج، لأبو زكريـا النووي ، الناشـر : دار إحياء التراث العربي - بيروت، الطبعـة: الثانيـة،

\section{Irqr}

• ب ا - المهذب في فقة الإمام الثافعي، المؤلف: أبو اسحاق إبراهيم بن علي بن يوسف الثيرازي ، الناشر : دار الكتب العلمية اب ا - الموازنــة بـين المصـالح والمفاســـــي التـداوي بنقـل الأعضــاء البشريـة لعبد الغني يحياوي، منشـورات مؤسسـة الغرقان للتراث

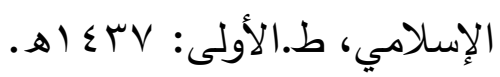


rس ا - مواهب الجليل في شرح مختصـر خليل، للطرابلسي المغربي، المعـروف بالحطـاب الرُّعينـي المـالكي ، الناشــر : دار الفكـرة

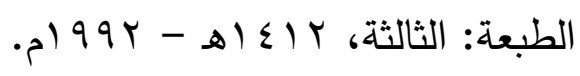

rس ا - الموسوعة الطبية الفقهية لأحمد كنعان ط. دار البصائر. ع ا - الموسوعة الفقهية الكويتية. صسادر عن: وزارة الأوقاف والشئون الإسلامية - الكويت، مطابع دار الصفوة الناشر : رمادى للنشر

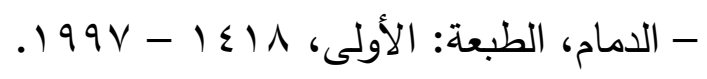

هب ا - النجم الوهاج في شرح المنهاج، لكمال الدين، أبو البقاء الشافعي

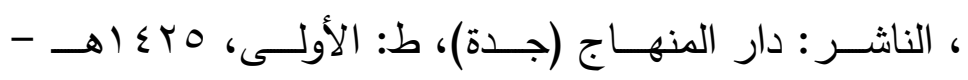

$$
\cdot r^{2} \cdot \boldsymbol{s}
$$

جس ا- - النكت الدالة على البيان في أنواع العلوم والأحكام، للقصَّاب ،

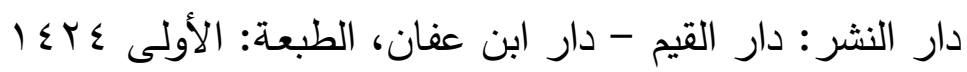

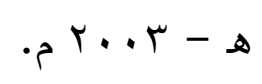

I I - نهايـة المحتاج إلى شـرح المنهاج، لشمس الدين الرملي ، دار

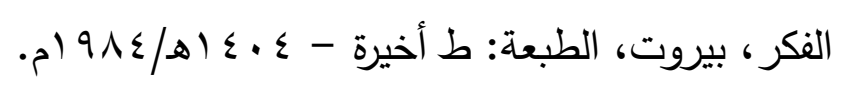

^ץ ا - النهاية في غريب الحديث والأثر ، ل مجد الدين أبو السعادات الثيباني الجزري ابن الأثير الناشر : المكتبة العلمية - بيروت،

$$
\text { . ) } 9 \vee 9-81499
$$

وب ا - نيل الأوطار ، لمحمد الثوكاني اليمني ، دار الحديث، مصر. • ــ - الهداية في شرح بداية المبتدي لعلي بن الفرغاني المرغيناني،

$$
\text { الناشر : دار احياء التراث العربي - بيروت - لبنان. }
$$




\section{توثيق الإذن الطبي دراسة فقهية مقارنة}

اء ا - الوثائق المختصـرة، أبو إسـاق الغرنـاطي، الجامعـة الإسـلامية

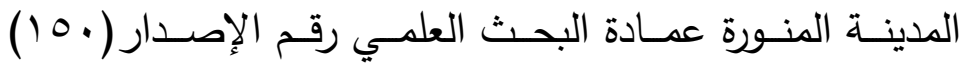

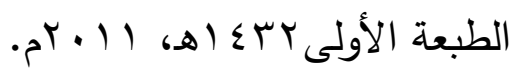

r ا ا - وسائل الثيعة للحرالمعاملي الناشر مؤسسة آل البيت.

وآخر دعوانا أن الحمد لله رب العالمين 


\section{فهرس الموضوعات}

TTV. الملخص: rel المقدمة rVT مشكلة البحث: . rVT الدراسات السابقة: . rV خطة البحث: rVV المبحث الأول: ماهية توثيق الإذن الطبي. rrV المطلب الأول: ماهية التوثيق rat المطلب الثاني: ماهية الإذن الطبي.. rAT تعريف الإذن الطبي: rNT ثانيًا تعريف الطبي: المطلب الثالث: العلاقة بين الإذن الطبي والإقرار الطبي والملف الطبي میبم

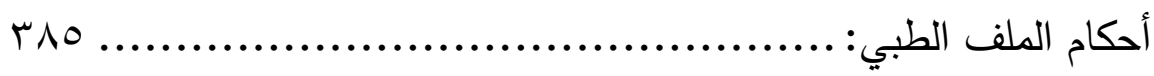
rAv المطلب الرابع: تعريف توثيق الإذن الطبي rงq المطلب الأول: أنواع الإذن الطبي. एq) المطلب الثالث: وسائل توثيق الإذن الطبي

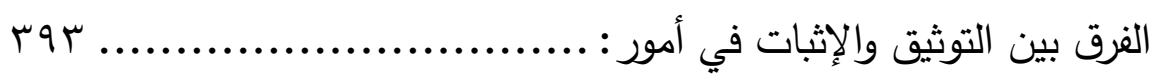
490 المطلب الأول: حكم كتابة الوثائق 


\section{توثيق الإذن الطبي دراسة فقهية مقارنة}

rqv

المطلب الثاني: أهمية توثيق الإذن الطبي...

$\varepsilon \cdots$ المبحث الرابع: شروط الموثق والإذن الطبي

$\varepsilon$ المطلب الأول: إسلام الموثق..

$\varepsilon \cdot 7$ المطلب الثاني : البلوغ والعقل. $\varepsilon \cdot 9$ المطلب الثالث عدالة الموثق... हाT المطلب الرابع: العلم بفقه الوثيقة. $\varepsilon 1 \leqslant$ المطلب الخامس: شروط الإذن الطبي 纟IV المطلب الأول: مشروعية الإذن الطبي $\varepsilon r q$ المطلب الثاني: حكم توثيق الإذن الطبي $\varepsilon \leqslant \vee$ المطلب الثاني: حوكمة توثيق الإذن الطبي $\varepsilon \varepsilon q$

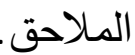

$\leqslant 01$ الخاتمة ...

sor

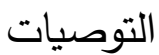

$\leqslant 0 \leqslant$ فهرس المراجح . $\leqslant \vee 1$ فهرس الموضوعات.

* $* \quad * \quad * \quad *$ 